\title{
LA REGULACIÓN DEL ERROR EN EL Código PENAL de Nicaragua
}

\author{
MARÍA A. TRAPERO BARREALES \\ Profesora Titular de Derecho Penal \\ Universidad de Léon (España)
}

\begin{abstract}
Este artículo fue mi modesta contribución al Congreso de Derecho penal y Derecho procesal penal "La reforma de la justicia penal en Nicaragua: Avances y perspectivas", organizado en el mes de noviembre de 2004 en homenaje al Prof. Diego-Manuel Luzón Peña con motivo de su Doctorado honoris causa por la Universidad Centroamericana UCA de Managua. Que su publicación, debidamente actualizado, sirva para reiterar de nuevo mi más sincero reconocimiento, al penalista, cabeza visible de una prestigiosa escuela científica, y, sobre todo, a la persona ejemplar.
\end{abstract}

\section{Introducción ${ }^{1}$}

\section{A pesar de las importantes aportaciones de penalistas tan significativos}

1 Abreviaturas utilizadas: ADP: Anuario de Derecho Penal y Ciencias Penales (revista española citada por año); AT: Allgemeiner Teil; BGH: Bundesgerichtshof (Tribunal Supremo alemán); CDJ: Cuadernos de Derecho Judicial (colección periódica editada por el Consejo General del Poder Judicial, citada por año y tomo); Coords.: Coordinadores; CP: Código Penal; Dir.: Director; DP: Derecho Penal; EJB: Enciclopedia Jurídica Básica (varios tomos, director, Alfredo Montoya Melgar, coordinador del área de Derecho Penal, Diego-Manuel Luzón Peña); EPB: Enciclopedia Penal Básica (director, Diego-Manuel Luzón Peña); FS Spendel: Festschrift für Günther Spendel, Walter de Gruyter, Berlin, 1992; FS Würtenberger: Festschrift für Thomas Würtenberger, Duncker Humblot, Berlin, 1977; JZ: Juristenzeitung (Revista alemana citada por año); LH Casabó: Estudios jurídicos en memoria del profesor Dr. D. José Ramón Casabó Ruiz, dos volúmenes, Universidad de Valencia, 1997; LH Cerezo: La ciencia del Derecho penal ante el nuevo siglo. Libro homenaje al profesor doctor Don José Cerezo Mir, Tecnos, Madrid, 2002; LH Roxin (Lisboa): Problemas fundamentais de Direito penal. Homenagem a Claus Roxin, Universidade Lusíada, Lisboa, 2002; LH Torío: El nuevo Código penal: presupuestos y fundamentos. Libro homenaje al profesor Doctor Don Ángel Torío López, Comares, Granada, 1999; LH Valle Muñiz: El nuevo Derecho penal español. Estudios penales en memoria del profesor José Manuel Valle Muñiz, Aranzadi, Pamplona, 2001; LL: Revista jurídica La Ley (revista española citada por año y tomo); MschKrim: Monatschrift für Kriminologie und Strafrechtsreform (revista alemana citada por año); N., nn.: nota, notas; Op. cit.: obra citada; P., pp.: página, páginas; PCP: Proyecto de Código Penal; PE: Parte Especial; PG: Parte General; PJ: Poder Judicial (revista española citada por número y año); S., ss.: siguiente, siguientes; StGB: Strafgesetzbuch (Código Penal alemán); STS: Sentencia del Tribunal Supremo; TS: Tribunal Supremo (español); Vid.: véase; ZStW: Zeitschrift für die gesamte Strafrechtswissenschaft (revista alemana citada por número y año). En la realización de este comentario se ha prescindido conscientemente de la cita exhaustiva de doctrina, para no alargar excesivamente la extensión del mismo. El presente trabajo se inscribe en los proyectos de investigación SEJ2007-60312 (Ministerio de Educación y Ciencia) y LE017A08 (Junta de Castilla y León), de los que el Prof. Dr. D. Miguel Díaz y García Conlledo es el investigador principal, y de cuyo equipo de investigación formo parte. 
en los últimos tiempos como ROXIN² en la doctrina alemana o LUZÓN PEÑA $^{3}$ en la doctrina española, la teoría del error sigue siendo una de las cuestiones más conflictivas y debatidas en DP. Tal es así que ni siquiera existe unanimidad en la terminología que ha de ser empleada para abordar su tratamiento ${ }^{4}$.

\section{Con todo, doctrina y jurisprudencia han alcanzado un mínimo consenso sobre algunos de los problemas que plantea el error en DP, lo que ha permitido que las legislaciones de los países europeos e iberoamericanos hayan regulado expresamente esta materia en los $\mathrm{CP}$ que han ido apareciendo a partir de la segunda mitad del siglo XX, admitiendo plenos efectos eximentes o atenuantes al error en este sector del ordenamiento jurídico, atendiendo a si éste es vencible o invencible ${ }^{5}$.}

2 Los trabajos de ROXIN directamente relacionados con el error son los siguientes: Die Irrtumsregelung des Entwurfs 1960 und die strenge Schuldtheorie, en: MschKrim 1961, 211-221; Die Behandlung des Irrtums im Entwurf 1962, en: ZStW 76 (1964), 582-618; Recensión a la obra de Platzgummer, Die Bewußtseinsform des Vorsatzes, 1964, en: ZStW 78 (1966), 248-261; Offene Tatbestände und Rechtspflichtmerkmale, Cran de Gruyter, Hamburg, 1959, 2a , Walter de Gruyter, Berlin, 1970 (= Teoría del tipo penal. Tipos abiertos y elementos del deber jurídico, traducción de la $2^{\mathrm{a}}$ alemana por Enrique Bacigalupo, Depalma, Buenos Aires, 1970); Gedanken zum "dolus generalis", en: FS Wüntenberger 1977, 109-128; Ungelöste Probleme beim Verbotsirrtum, en: HIRSCH (editor), Deutsch-Spanisches Strafrechtskolloquium 1986. Dogmatischer Teil der Strafrechtsreform. Santionensystem. Bekämpfung der Wirtschaftskriminalität, Nomos, Baden-Baden, 1987, 81-88; Rose-Rosal redivivus, en: FS-Spendel 1992, 289-301; Die Abgrenzung von untauglichen Versuch und Wahndelikt, en: JZ 1996, 981-987 (= La delimitación entre tentativa inidónea y delito putativo, en: Dogmática penal y política criminal, traducción y edición a cargo de Abanto Vásquez, Idemsa, Lima, 1998, 317-344 = en: La teoría del delito en la discusión actual, traducción de Abanto Vásquez, Grijley, Lima, 2007, 435-460); ; Strafrecht. Allgemeiner Teil I. Grundlagen. Der Aufbau der Verbrechenslehre, $4^{\mathrm{a}}$, CH Beck, 2006, 481-535, 622-644, 925-961, 791-825 (= Derecho Penal. Parte General I. Fundamentos de la estructura de la teoría del delito, traducción de la $2^{\mathrm{a}}$ alemana y notas de Diego-Manuel Luzón Peña, Miguel Díaz y García Conlledo, Javier de Vicente Remesal, Civitas, Madrid, 1997, 456-508, 579-601, 859-894); Acerca del error en el Derecho penal, en: La teoría del delito en la discusión actual, traducción de Abanto Vásquez, Grijley, Lima, 2007, 195-224.

3 Los trabajos de LUZÓN PEÑA directamente relacionados con el error son los siguientes: El error sobre las causas de justificación: algunas precisiones (comentario a la STS 10-5-1989), en: LL 1989-3, 572-581 (= en: Estudios Penales, PPU, Barcelona, 1991, 67-82 = en: Boletín de la Facultad de Derecho de la Universidad Española a Distancia, 1992, 135-147); Concurrencia aparente o real del error sobre los presupuestos o límites de una causa de justificación (error sobre la ilegalidad de una detención intimidatoria de autoridad por funcionario), en: PJ 19 (1990), 281-301 (= en: Estudios Penales, PPU, Barcelona, 1991, 83-111 = en: LL 1991-1, 349-364); Error de tipo y error de prohibición, en: EJB II, 1995, 2838-2845; Error sobre las causas de justificación, en: EJB II, 1995, 2845-2852; Curso de Derecho Penal. Parte general I, Universitas, Madrid, 1996, 437-486; Error de tipo y error de prohibición, en: EPB 2002, 655-664; Error sobre las causas de justificación, en: EPB 2002, 664-671; Error objetivamente invencible, caso fortuito, consentimiento presunto: causas de justificación o de exclusión de la tipicidad penal, en: CDJ 2006-VII, 359-371.

4 Así, aunque la doctrina mayoritaria utiliza los conceptos error de tipo y error de prohibición para hacer referencia al error en DP aún se sigue utilizando la terminología tradicional, que no el tratamiento tradicional, que diferencia entre el error de hecho y el error de Derecho. Para más detalles sobre la utilización en la doctrina reciente de la distinción entre el error de hecho y el error de Derecho, vid., ampliamente, DÍAZ Y GARCÍA CONLLEDO, El error sobre los elementos normativos del tipo penal, La Ley, Madrid, 2008, 221 ss., quien cita, en la doctrina alemana reciente a autores como BURKHARDT, KINDHÄUSER y RINK, entre otros.

5 Así, la regulación del error de tipo y el error de prohibición, empleando esta u otra terminología para su denominación, se ha regulado, entre otros, en el CP de Costa Rica de 1970 (arts. 34 y 35. En este país existe un PCP del año 1998 en el que se proponen cambios significativos en la regulación del error, arts. 25 y 32); en el StGB alemán tras la aprobación de la reforma de la PG en el año 1975 ( $§ 16$ y 17. Con anterioridad sólo se regulaba el error de tipo, en el antiguo § 59); en el CP portugués de 1982 (arts. 16 y 17); en el CP español de 1944/1973 tras la reforma aprobada en 1983 (art. 6 bis a) y en el actual CP 1995 (art. 14); en el CP brasileño de 
A esta corriente legislativa del Derecho Comparado se ha adherido el legislador nicaragüense con su decisión de regular, por primera vez con carácter general, el tratamiento del error en DP: en el Capítulo I (relativo a los delitos y faltas), del Título I (dedicado a la infracción penal), del Libro I (sobre las disposiciones generales sobre los delitos, las faltas, penas, medidas de seguridad, consecuencias accesorias de la infracción penal y de las personas responsables) del CP, a través de los arts. 25 y 26, en los que se diferencia entre el error de tipo y el error de prohibición, utilizando expresamente esta terminología en las rúbricas de ambos preceptos, una regulación que coincide sustancialmente con la prevista en el CP español (art. 14), por lo que la interpretación de la doctrina española en torno a este precepto nos será de gran utilidad en la exégesis de la regulación del error en el CP nicaragüense ${ }^{6}$.

Pero si bien lo expuesto hasta ahora serviría para justificar o, al menos, para explicar esta decisión legislativa de regular expresamente el tratamiento del error en el DP nicaragüense, tal opción puede ser puesta en entredicho por cuanto podría resultar innecesaria si atendemos a que un $\mathrm{CP}$ es un cuerpo ordenado y sistematizado, inspirado en unos principios básicos que actúan como límites (y orientadores) de la potestad punitiva del Estado. Tal duda surge porque, aunque no suele ser habitual (al menos en los CP europeos) que tales principios limitadores del ius puniendi aparezcan mencionados expresamente en el CP, el legislador nicaragüense ha optado por la decisión contraria, incluyendo en el Título Preliminar, sobre las garantías penales y de la aplicación de la ley penal, varios de estos principios ${ }^{7}$, entre ellos los

1940 tras la aprobación de la reforma operada en 1984 (arts. 20 y 21); en el CP peruano de 1991 (art. 14. En Perú existe un Anteproyecto de CP de 2004, en el que se propone añadir la regulación del error sobre las causas de atenuación a la regulación ya existente sobre el error de tipo y el error de prohibición); en el CP mexicano tras la reforma de 1994 (arts. 15.VIII.A y B y 66) y en el CP colombiano de 2000 (art. 32. apartados 10, 11 y 12).

6 La regulación del CP nicaragüense es la siguiente: Art. 25 "Error de tipo/1. El error invencible sobre un hecho constitutivo de la infracción penal excluye la responsabilidad penal. Si el error fuera vencible, la infracción será castigada, en su caso, como imprudente./2. El error sobre un hecho que califique la infracción o sobre una circunstancia agravante, impedirá la apreciación de la circunstancia calificadora o agravante." Y art. 26: "Error de prohibición./1. El error invencible sobre la ilicitud del hecho constitutivo de la infracción penal excluye la responsabilidad penal./2. Si el error sobre la prohibición del hecho fuera vencible, se impondrá una pena atenuada cuyo límite máximo será el límite inferior de la pena prevista en la ley para el delito o falta de que se trate y cuyo límite mínimo podrá ser la mitad o la cuarta parte de éste". Y la regulación del CP español vigente es la siguiente: art. 14: "1. El error invencible sobre un hecho constitutivo de la infracción penal excluye la responsabilidad criminal. Si el error, atendidas las circunstancias del hecho y las personales del autor, fuera vencible, la infracción será castigada, en su caso, como imprudente./2. El error sobre un hecho que cualifique la infracción o sobre una circunstancia agravante, impedirá su apreciación./3. El error invencible sobre la ilicitud del hecho constitutivo de la infracción penal excluye la responsabilidad criminal. Si el error fuera vencible, se apreciará la pena inferior en uno o dos grados".

7 Concretamente se han regulado los siguientes principios limitadores del ius puniendi: el principio de legalidad 
Revista de Derecho

principios de responsabilidad subjetiva y de culpabilidad, empleando esta terminología en su denominación.

Pues bien, aunque sigue siendo objeto de discusión cuál ha de ser la ubicación sistemática y los efectos del error de tipo y del error de prohibición, lo que ya no es objeto de controversia es que el error en DP tiene efectos atenuatorios o excluyentes de la responsabilidad penal, pudiéndose construir como una especie de reverso de los principios anteriormente mencionados. Así, el principio de responsabilidad subjetiva se enuncia de la siguiente manera: no hay pena (o medida de seguridad) sin dolo o imprudencia, mientras que el error de tipo (con independencia de la definición concreta del dolo y de la imprudencia, y de su ubicación sistemática) es una causa de exclusión del dolo y, cuando es invencible, también de la imprudencia. Por su parte, el principio de culpabilidad supone que no hay pena sin culpabilidad, y además la pena ha de ser proporcional al grado de culpabilidad del sujeto, mientras que el error de prohibición (con independencia de si el conocimiento de la antijuridicidad es un elemento del dolo o es un elemento autónomo de la culpabilidad) es una causa de exclusión o atenuación de la culpabilidad $^{8}$.

De todas formas puede resultar, si no necesaria, sí conveniente la regulación expresa del error de tipo y, sobre todo, del error de prohibición en elCP nicaragüense ${ }^{9}$, dado que en el antiguo CP no existía una regulación

(art. 1), el principio de irretroactividad y de retroactividad (arts. 2 y 3), el principio de dignidad humana (art. 4), el principio de reconocimiento y protección de la víctima (art. 5), el principio de lesividad (art. 7), los principios de responsabilidad personal y humanidad (art. 8) y los principios de responsabilidad subjetiva y de culpabilidad (art. 9).

8 La doctrina mayoritaria no suele diferenciar entre estos dos principios, aunque se admita que el dolo y la imprudencia forman parte del tipo (o del tipo de injusto), empleando solamente el principio de culpabilidad para hacer referencia a una doble exigencia: primera, que no puede haber pena (o medida de seguridad, según el CP nicaragüense) sin dolo o imprudencia, y segunda, que no puede haber pena sin culpabilidad, y que la pena ha de ser proporcional al grado de culpabilidad del sujeto. Para más detalles sobre los principios de culpabilidad y de responsabilidad subjetiva, y las razones para la utilización de estas dos expresiones y no la tradicional y única de principio de culpabilidad, por todos, LUZÓN PEÑA, PG, I, 1996, 86 ss. Por otro lado, la diferencia entre los principios de responsabilidad subjetiva y de culpabilidad, así como su distinto significado a la hora de valorar las posibles consecuencias jurídicas derivadas de la comisión de un delito (la imposición de una pena o de una medida de seguridad), pueden ser argumentos que sirvan para considerar que el dolo y la imprudencia son elementos del tipo (entendido este término en el sentido de tipo indiciario o como tipo global de injusto) tal como se defiende por la doctrina mayoritaria en Alemania y en España (vid., para más detalles sobre esta cuestión, LUZÓN PEÑA, Op. cit., 238 ss., 330 ss.): porque para que se pueda imponer una pena es necesario que el sujeto actúe dolosa o, excepcionalmente, imprudentemente, y que además sea culpable, pero para la imposición de una medida de seguridad sólo se exige que el sujeto actúe dolosa o imprudentemente, sin necesidad de que además sea culpable; de la diferenciación entre el dolo y la imprudencia por un lado y la culpabilidad por otro se podría derivar que los dos primeros elementos ya no forman parte de la culpabilidad, sino que serán elementos de la tipicidad (o del tipo global de injusto).

9 El legislador nicaragüense ha optado por la regulación genérica de las dos clases de error (el de tipo y el de prohibición), sin incluir expresamente en ninguna de las dos categorías el supuesto más controvertido en la actualidad, el error sobre las causas de justificación (y más concretamente, el error directo sobre la concurrencia 
general sobre el error, tan solo había una referencia a determinadas clases especiales del error de tipo ${ }^{10}$, y son conocidas las dificultades que han existido en los Tribunales de países como Alemania y España para admitir los efectos eximentes o atenuantes de la responsabilidad penal en el error de prohibición antes de su reconocimiento legal en los CP de ambos países ${ }^{11}$.

de los presupuestos objetivos de las causas de justificación). Con esta decisión el CP nicaragüense se desmarca de las corrientes reformistas de algunos CP de países iberoamericanos, en los que se ha optado por regular expresamente esta clase de error (bien como una modalidad del error de tipo -es el caso de los CP de Costa Rica, Brasil y Colombia-, bien como una modalidad del error de prohibición -es el caso, aparentemente al menos, del CP mexicano y del PCP de 1998 de Costa Rica-), siguiendo en esta materia la opción de la mayoría de los CP europeos que han optado por no hacer ninguna mención específica a esta modalidad de error (si bien también en algunos países europeos se ha optado por la regulación del error sobre la concurrencia en el hecho de los presupuestos objetivos de una causa de justificación, como por ejemplo, en los CP austríaco e italiano).

10 En el antiguo CP nicaragüense no existía una regulación general sobre el error, tan solo había un precepto (el art. $5 \mathrm{CP}$ anterior) en el que se admitía algún efecto atenuatorio a alguna de las modalidades especiales de error de tipo: claramente se admitía tal efecto atenuante en el error in persona y la preterintencionalidad, pero en una interpretación menos apegada al tenor literal, también se podía incluir en ese mismo precepto al error in objeto, la aberratio ictus y el error sobre elementos accidentales del tipo. En concreto, el art. 5 CP anterior disponía lo siguiente: "El que ejecutare el hecho punible será responsable de él e incurrirá en la pena que la ley señala, aunque varíe el mal que se propuso causar o recaiga sobre persona distinta de aquella a quien se proponía ofender. En tal caso no se tomarán en consideración las circunstancias no conocidas por el delincuente que agravarían su responsabilidad, pero sí aquellas que la atenúan”. Pero no sólo faltaba una regulación general del error de tipo, sino que además existían algunos preceptos que implicaban el mantenimiento de la responsabilidad por el resultado, lo que materialmente significaba la negación de plenos efectos al error de tipo (por ser el error de tipo una consecuencia de la vigencia del principio de responsabilidad subjetiva). Así, desde esta perspectiva cabe mencionar, por un lado, el castigo en el CP anterior de las conductas dolosas, las preterintencionales y las imprudentes (art. 2, en el que se definía el dolo, la preterintención y la imprudencia), y, por otro lado, la existencia en el CP anterior de algunos preceptos penales que, atendiendo a su redacción, podían ser interpretados desde la admisión de la responsabilidad por el resultado (por ejemplo, los delitos de exposición de personas al peligro, arts. 154 ss.). En cuanto al error de prohibición, faltaba un precepto que regulara expresamente la atenuación o exclusión de la responsabilidad criminal aplicable cuando el sujeto desconocía la antijuridicidad de su conducta, si bien podía tener cierta relación con esta clase de error la circunstancia atenuante referida a la falta de discernimiento o instrucción del sujeto (art. 29.15 $\mathrm{CP}$ anterior).

11 En Alemania y España, antes de la regulación del error en los CP respectivos, durante mucho tiempo la jurisprudencia distinguía entre el error de hecho, relevante, y el error de Derecho, irrelevante, y para mitigar los efectos de esta diferenciación dentro del error de Derecho se planteaba a su vez la distinción entre el error de Derecho extrapenal, que sí era relevante y se asimilaba en su tratamiento al error de hecho, y el error de Derecho penal, irrelevante. En Alemania, a partir de una decisiva sentencia del BGH de 18 de marzo de 1952, se admitió sin mayores problemas la relevancia del ya denominado error de prohibición, al aceptarse por el Alto Tribunal alemán la teoría de la culpabilidad en su tratamiento (y no sería hasta 1975 que el legislador alemán no regulara el error de prohibición en el § 17 StGB). En España, a pesar de los esfuerzos de la doctrina por hallar una explicación a la admisión del error de prohibición como eximente o atenuante de la responsabilidad penal, el TS siguió rechazando cualquier efecto a esta clase de error, partiendo en sus planteamientos del principio error iuris nocet, si bien tal línea jurisprudencial coincidía en el tiempo con otros pronunciamientos del TS español en los que se admitía la eficacia del error de prohibición o error de Derecho, defendiendo el TS en estas sentencias la teoría del dolo. Sólo a partir de la reforma aprobada en 1983, al incluirse expresamente la regulación del error en DP (en el art. 6 bis a CP 1944/1973 -CP ya derogado-), se consiguió dar un paso definitivo para reconocer plenos efectos al error de prohibición, terminando de este modo con las erráticas y desacertadas doctrinas jurisprudenciales existentes en nuestro país en el tratamiento de esta clase de error. Para más detalles sobre esta fase histórica en la que predominaba el principio error iuris nocet en la jurisprudencia española y alemana, vid., por todos, LUZÓN PEÑA, PG, I, 1996, 464 s.; ROXIN, AT, I, 4ª 2006, 928 ss. (= PG, I, 1997, 862 s.). 
Revista de Derecho

\section{La distinción entre el error de tipo y el error de prohibición}

Como se ha indicado anteriormente, el CP nicaragüense (arts. 25 y 26) se ha inspirado en el CP 1995 español (art. 14) en la regulación del error, si bien ha introducido algunas modificaciones en su texto que han de ser valoradas positivamente, al resolver algunas de las dudas y/o críticas que se han planteado en la interpretación del texto punitivo español.

Al igual que el CP español, en el CP nicaragüense se diferencia, inicialmente al menos, entre el error sobre un hecho constitutivo de la infracción penal (art. 25)/el error sobre la ilicitud del hecho constitutivo de la infracción penal (art. 26), ya que en esta segunda modalidad de error junto con la anterior terminología también se emplea la de error sobre la prohibición del hecho. Si atendiéramos solamente a aquel par de expresiones se plantearía la misma duda que en la doctrina española se ha suscitado en la interpretación de los mismos términos en el CP español, ya que tal conceptuación del error no coincide ni con la tradicional distinción entre el error de hecho/error de Derecho, ni con la moderna diferenciación entre el error de tipo/error de prohibición. La utilización de aquellas dos expresiones, "error de hecho/error sobre la ilicitud del hecho", ha provocado que la doctrina española, sobre todo en los primeros escritos aparecidos tras la aprobación del CP 1995 español, haya elevado duras críticas al legislador debido a la dificultad de decidir con qué término puede ser identificado el error sobre los elementos normativos del tipo ${ }^{12}$, si ha de ser entendido como un error de hecho o

12 En DP es tradicional la distinción entre elementos descriptivos y elementos normativos del tipo: los primeros se definen como aquellos elementos para cuyo conocimiento y comprensión basta con el común saber empírico y lógico de los hombres sobre sí mismos y sobre las realidades y fenómenos del mundo exterior. Y los elementos normativos son aquellos que requieren para el conocimiento y comprensión de su alcance y significado el conocimiento de alguna norma, de la clase que sea (jurídica, social, ética...). Ésta es la distinción que proponen LUZÓN PEÑA, en: EJB, II, 1995, 2841; PG, I, 1996, 351; en: EPB, 2002, 658 s.; DÍAZ Y GARCÍA CONLLEDO, Los elementos normativos del tipo penal y la teoría del error, en: LH Casabó, I, 1997, 660 ss. [= en: LUZÓN PEÑA/MIR PUIG (Coords.), Cuestiones actuales de la teoría del delito, 1999, 63 ss.]; Error elementos normativos del tipo, 2008, 45 ss., 66 ss. Este último autor propone la siguiente clasificación de los elementos normativos del tipo (completada y/o ampliada la clasificación en la última obra citada, Error elementos normativos del tipo, 2008, 81 ss.): elementos normativos específicos o explícitos y elementos normativos generales o implícitos, elementos normativos del tipo objetivo y del tipo subjetivo, elementos normativos del tipo positivo y del tipo negativo y elementos normativos jurídicos y elementos extrajurídicos, y a su vez, entre los elementos normativos jurídicos, distinguiendo entre elementos normativos jurídicopenales y extrapenales, y en el caso de elementos normativos extrajurídicos, entre elementos normativos de sentido y elementos normativos de valor. Como ejemplos de elementos normativos, teniendo en cuenta las distintas clasificaciones, cita DÍAZ Y GARCÍA CONLLEDO los siguientes (adaptando estos ejemplos al CP nicaragüense, sin que la cita de preceptos de este texto punitivo sea exhaustiva): elementos normativos específicos, carácter particularmente degradante (arts. 4, 18.f, 490, $491 \mathrm{CP}$ nicaragüense), material pornográfico (art. 175.3 CP nicaragüense), dignidad y fama (art. $203 \mathrm{CP}$ nicaragüense), matrimonio (arts. 36.11, 180, 210, 211, 212 CP nicaragüense), tutela y guarda (arts. 58, 155, 159, 161, 183, 216, 217, 218 CP nicaragüense), acreedores (arts. 258, 259, 260, 280 CP nicaragüense), impuestos (arts. 303 a 


\section{como un error sobre la ilicitud del hecho, o incluso si tal error sobre los elementos normativos del tipo no está regulado expresamente, por lo que es necesario recurrir a la aplicación analógica para su tratamiento o, lo que sería injustificable, estaríamos ante un error irrelevante ${ }^{13}$. A}

308, 455, 549 CP nicaragüense), documento (arts. 39, 195, 222, 265, 275, 280, 284 ss., 372, 432, 440, 441, 451, 466, 477 CP nicaragüense), título académico (art. 298 CP nicaragüense), nicaragüense (arts. 14, 15, 16, $409 \mathrm{CP}$ nicaragüense), autoridad, funcionario o empleado público -a veces se emplean las tres expresiones, a veces sólo alguna de ellas- (arts. 38, 165.c. e. y f, 166, 199, 201, 204.d, 213, 216, 222, 226, 227, 258, 270, 280, 283, 290, 302, $309,313,314,318,321,338,347,362 . c, 363,372,395,408,409,421,422,426,430,431,432$ a 459, 460, 461.c, $468,469,471 . b, 482,486,488,528,531,532,533,542,558 \mathrm{CP}$ nicaragüense), la ajenidad en los delitos contra el patrimonio (arts. 219 ss. CP nicaragüense); elementos normativos del tipo negativo, los conceptos de agresión ilegítima, morada y dependencias, agresión a los bienes que sea constitutiva de delito (art. 34.4 CP nicaragüense), en el estado de necesidad los términos bien jurídico y mal (art. 34.5 CP nicaragüense); elementos normativos jurídicopenales: los términos delito o falta empleados en general o concretándolos en algunos delitos específicos (ejemplos, entre otros, los arts. 34.4, 222, 346.2, $470 \mathrm{CP}$ nicaragüense), el concepto de autoridad, funcionario y empleado público (en los arts. anteriormente citados), el concepto de incapaz (art. $40 \mathrm{CP}$ nicaragüense y restantes preceptos en los que se otorga especial protección a este sujeto pasivo), el concepto de documento (en los arts. anteriormente mencionados), el concepto de robo y el de llaves falsas en el robo con fuerza en las cosas (art.223 CP nicaragüense); elementos normativos jurídicos extrapenales: la ajenidad en los delitos contra el patrimonio (en los arts. anteriormente mencionados), matrimonio (en los arts. anteriormente mencionados), tutela y guarda (en los arts. anteriormente mencionados), arriendo, depósito o administración (art. 457 CP nicaragüense), quiebra y concurso (arts. 258 a $260 \mathrm{CP}$ nicaragüense), impuestos (en los arts. anteriormente mencionados), Asamblea Nacional (art. 439 CP nicaragüense); elementos normativos extrajurídicos, fama (art. 203 CP nicaragüense), trato o prácticas degradantes (arts. 4, 18.f, $491 \mathrm{CP}$ nicaragüense), material pornográfico (art. $175 \mathrm{CP}$ nicaragüense), trato cruel (art. 391 CP nicaragüense), ultrajar o vilipendiar (art. 191 CP nicaragüense); elementos normativos de valor, los anteriormente mencionados; elementos normativos de sentido, como funcionario o documento (en los arts. anteriormente mencionados). Como elementos afines a los elementos normativos del tipo, y son afines porque plantean los mismos problemas en cuanto a la concepción del dolo y el tratamiento del error que los elementos normativos del tipo, cita DÍAZ Y GARCÍA CONLLEDO, Error elementos normativos del tipo, 2008, 97 ss., los siguientes: elementos teóricos o cognoscitivos del tipo y los del ámbito técnico o especializado, los conceptos complejos, los elementos de valoración global del hecho (y los problemas para su diferenciación de la referencia expresa en algunos tipos a la ausencia de causas de justificación), algunos elementos de los delitos de omisión -en concreto, en el requisito de la posición de garante en los delitos de comisión por omisión-, y las leyes penales en blanco (cita este autor un gran número de ejemplos de todas estas categorías desde la perspectiva del Derecho penal español).

13 Vid., entre otros, BACIGALUPO ZAPATER, Problemas del error, en: LL 1996-3, 1429; Principios de DPPG, $5^{\text {a }}$, Akal, Madrid, 1998, 233 ss., quien advierte que la regulación del error prevista en el art. 14 CP español mezcla el error sobre la ilicitud del hecho y el error de hecho, pues todos los elementos del tipo y de la antijuridicidad son elementos de lo ilícito, por lo que el error que se engloba en el apartado $3^{\circ}$ del art. 14 CP español se superpondría con el error sobre los hechos del apartado $1^{\circ}$ del mismo precepto penal, porque éstos pertenecen a lo ilícito. Añade este autor que esta regulación crea la duda de cómo debe tratarse el error sobre elementos normativos del tipo, pues son elementos que no son de hecho ni de la ilicitud en sentido estricto. A falta de una regulación expresa sobre el error en relación con los elementos normativos del tipo, este autor propone dos soluciones: considerar que este error es irrelevante, solución que rechaza, o recurrir a la analogía con el error de tipo o con el error de prohibición, optando BACIGALUPO ZAPATER por el recurso a la analogía con el error de tipo; RODRÍGUEZ MOURULLO, en: RODRÍGUEZ MOURULLO (dir.)/JORGE BARREIRO (coord.), Comentarios al CP, Civitas, Madrid, 1997, 66, quien pone de relieve las dificultades que se plantean en el CP español a la hora de resolver el error sobre los elementos normativos del tipo, optando finalmente este autor por aplicar las reglas del error de tipo -art. 14.1 CP español- en el tratamiento de esta clase especial de error, al menos esa es la conclusión a la que parece llegar; CEREZO MIR, Curso de DP español. PG II. Teoría jurídica del delito, 6 $6^{\mathrm{a}}$, Tecnos, 1998, 134, quien recurre a la interpretación teleológica del art. 14.1 CP español para entender que el fin perseguido por la norma es la regulación del error sobre un elemento del tipo, sea descriptivo o sea normativo. Y añade este autor que, de descartase esta interpretación, para el tratamiento del error sobre los elementos normativos del tipo no se podría recurrir a la analogía in bonam partem con la regulación del error sobre un elemento del tipo, porque en opinión de este autor en el CP español no se puede apreciar eximentes por analogía (n. 58, p. 134); RAMOS TAPIA, en: ZUGALDÍA ESPINAR (dir.)/PÉREZ ALONSO (coord.), DPPG, 2a, Tirant lo Blanch, Valencia, 2004, 511, quien incluye el error sobre los elementos normativos del tipo en el art. 14.1 CP español, a pesar de que la redacción de este apartado parezca querer limitar el error a los hechos, esto es, a los elementos descriptivos o fácticos; BUSTOS RAMÍREZ/HORMAZÁBAL MALARÉE, Lecciones de DPPG, 2a , Trotta, Madrid, 2006, 364, quienes 

los pares de conceptos error de hecho/error sobre la ilicitud del hecho deben interpretarse o entenderse como equivalentes a los de error de tipo/error de prohibición ${ }^{14}$, y respecto del error sobre los elementos normativos del tipo habrá que aclarar previamente qué supuestos van

advierten que el art. 14 CP español no ha resuelto expresamente el error sobre los elementos normativos del tipo, y proponen estos autores resolver este problema a través de la interpretación -en concreto, proponen recurrir a las reglas de la analogía in bonam partem con la regulación contenida en el art. 14.1 CP español, p. 366-; ARIAS EIBE, El error en DP en el Código de 1995, Dykinson, Madrid, 2007, 81 s., quien admite que el error sobre los elementos normativos del tipo es un supuesto de error que no está resuelto en el art. 14 CP español, si bien a continuación defiende que la solución correcta es tratar dicho error como un error de tipo; DÍEZ RIPOLLÉS, DP español. PG en esquemas, Tirant lo Blanch, Valencia, 2007, 175, quien afirma que la interpretación literal del art. 14.1 CP español no avala que la mención a hecho constitutivo de la infracción penal deje fuera los elementos normativos; QUINTERO OLIVARES, PG del DP, 2a , Thomson-Aranzadi, Pamplona, 2007, 438 s., quien, tras criticar el tenor literal del art. 14.1 CP español, por las dificultades para resolver satisfactoriamente el error sobre los elementos normativos del tipo, propone recurrir a una interpretación sistemática y teleológica, de modo que acaba concluyendo que el art. 14.1 CP español se refiere al error sobre los elementos que aprehenden la descripción típica del hecho, abarcando así tanto los elementos descriptivos como los normativos. Para más detalles sobre las distintas opiniones doctrinales en torno al tratamiento del error sobre los elementos normativos del tipo como un error de hecho -error de tipo- o como un error sobre la ilicitud del hecho -error de prohibición-, o a través de otras soluciones alternativas, DÍAZ Y GARCÍA CONLLEDO, ¿Error de tipo o error de hecho?, en: LH Valle Muñiz, 2001, 191 ss., 209 ss.; Error elementos normativos del tipo, 2008, 189 a 424, y para el problema previo de si el error sobre los elementos normativos del tipo está o no regulado, en concreto, sobre los problemas sobre su posible inclusión o no en el art. 14.1 CP español a pesar de la utilización del término "error sobre un hecho constitutivo de la infracción penal".

14 Así lo han reconocido, entre otros, LUZÓN PEÑA, PG I, 1996, 439 ss., 462 ss.; en: EPB, 2002 , 664 ss.; RODRÍGUEZ MOURULLO, en: RODRÍGUEZ MOURULLO (dir.)/JORGE BARREIRO (coord.), Comentarios CP, 1997, 65; COBO DEL ROSAL/VIVES ANTÓN, DPPG, 5ª Tirant lo Blanch, Valencia, 1999, 680 (si bien estos autores prefieren utilizar los términos error sobre el tipo y error sobre la prohibición, tal como explican en p. 665 n. 26); MIR PUIG, Comentario al art. 14, en: COBO DEL ROSAL (dir.), Comentarios al CP, tomo I, Edersa, Madrid, 1999, 674 s., quien ha advertido que el término "hecho" empleado en el art. 14.1 CP español no es equivalente al término "hecho" empleado en el art. 14.3 CP español: en este último caso "el hecho" equivale al conjunto del supuesto de hecho ilícito, no a cualesquiera de sus elementos parciales, mientras que en el número $1^{\circ}$ se refiere a "un hecho" en el sentido de cualesquiera de los que integran el hecho constitutivo de la infracción de que se trate. Sigue argumentando este autor que el error sobre la ilicitud no significa desconocimiento de que el hecho concretamente realizado es ilícito, sino sólo desconocimiento de que la ley considera ilícito el "hecho constitutivo de la infracción penal". En definitiva, a juicio de MIR PUIG, el art. 14.3 CP español no comprende los casos de error de Derecho que consistan en un error sobre un elemento normativo jurídico integrante del supuesto de hecho de la infracción penal, sino sólo el desconocimiento de la ilicitud de dicho supuesto de hecho, por tanto, el error sobre los elementos normativos del tipo se incluye en el art. 14.1 CP español, en el que se regulan todos los supuestos de error de tipo (sobre esta postura, véase críticamente DÍAZ Y GARCÍA CONLLEDO, en: LH Valle Muñiz, 2001, 217 s. n. 37; Error elementos normativos del tipo, 2008, 196 n. 14, al considerar que tal entendimiento del art. 14.3 CP español impide admitir la eficacia eximente o atenuante del error de subsunción, entendido como aquel error que supone una interpretación errónea en la definición del elemento normativo jurídico, error de subsunción que a veces dará lugar a un error de prohibición, a veces podrá ser valorado como un error de prohibición penal); DPPG, 8ª Reppertor, Barcelona, 2008, 270 s., 557; ZUGALDÍA ESPINAR, Comentario al art. 14, en: COBO DEL ROSAL (dir.), Comentarios al CP, tomo I, 1999 , 679 s.; en: ZUGALDİA ESPINAR (dir.)/PÉREZ ALONSO (coord.), PG, 2a , 2004, 608; DÍAZ Y GARCÍA CONLLEDO, El error de prohibición: pasado, presente y futuro, en: LH Torío, 1999, 340 y n. 16, quien pone de relieve las dificultades interpretativas de la redacción del art. 14 CP español en relación con el tratamiento del error sobre los elementos normativos del tipo y, quizás, con el error sobre los presupuestos de las causas de justificación para su inclusión en el ámbito del error de tipo, si bien este autor acaba reconociendo que la regulación del CP español se basa en la distinción entre el error de tipo/error de prohibición; Error elementos normativos del tipo, 2008,192 ss.; BERDUGO GÓMEZ DE LA TORRE/ARROYO ZAPATERO/FERRÉ OLIVÉ/GARCÍA RIVAS/SERRANO PIEDECASAS/TERRADILLOS BASOCO, Curso de DPPG, Experiencia, Barcelona, 2004, 258 s.; RAMOS TAPIA, en: ZUGALDÍA ESPINAR (dir.)/PÉREZ ALONSO (coord.), PG, 2a , 2004, 509 ss.; DÍEZ RIPOLLÉS, PG, 2007, 175, 436; MARTÍNEZ-BUJÁN PÉREZ, DP económico y de la empresa. PG, $2^{\mathrm{a}}$, Tirant lo Blanch, Valencia, 2007, 396 ss.; MUÑOZ CONDE/GARCÍA ARÁN, DPPG, 7ª Tirant lo Blanch, Valencia, 2007, 275, 383; QUINTERO OLIVARES, PG, 2a , 2007, 436 ss. 
a ser tratados como errores de tipo y qué supuestos deben ser tratados como errores de prohibición (o como errores de prohibición penal) ${ }^{15}$.

Esta misma discusión podría plantearse en la interpretación del error en
el CP nicaragüense por la utilización del par de conceptos error de hecho/
error sobre la ilicitud del hecho en su redacción, si bien también puede
entenderse que la misma ha sido zanjada con la utilización de las rúbricas
"error de tipo", "error de prohibición" en las denominaciones de los arts. 25 y $26 \mathrm{CP}$ nicaragüense respectivamente y, en segundo lugar, porque en la redacción del art. $26 \mathrm{CP}$ nicaragüense se ha querido equiparar el error sobre la ilicitud del hecho al error de prohibición, tal como se desprende de la utilización de esta segunda expresión para redactar el error vencible de prohibición. Porque con la equiparación expresa entre el error de tipo = error de hecho, y el error de prohibición = error sobre la ilicitud del hecho, se puede entender que se reconoce de forma explícita que el error sobre un hecho constitutivo de la infracción penal ha de entenderse como equivalente a error de tipo ${ }^{16}$, y el término "hecho" no debe interpretarse como elemento puramente fáctico, sino como circunstancia descrita en el tipo, o como el conjunto de circunstancias o datos de los tipos, sean de carácter meramente fáctico o sean hechos con significado social, ético o jurídico, esto es, incluyendo también a los elementos normativos ${ }^{17}, \mathrm{y}$

15 En esta delimitación entre el error de tipo, de prohibición y de prohibición penal, y su posible repercusión en el tratamiento del error sobre los elementos normativos del tipo, se sigue la propuesta realizada en la doctrina española por LUZÓN PEÑA, en: EJB, II, 1995, 2841 s.; PG, I, 1996, 448 ss.; en: EPB, 2002, 658 s.; DÍAZ Y GARCÍA CONLLEDO, en: LH Casabó, I, 1997, 676 ss., 696 ss. [= en: LUZÓN PEÑA/MIR PUIG (Coords.), Cuestiones actuales de la teoría del delito, 1999, 80 ss., 102 ss.]; en: LH Valle Muñiz, 2001, 210 ss., 214 ss.; Error elementos normativos del tipo, 2008, 142 ss., 149 ss., 159 ss., 164, 189 ss., 210 ss., 219 al final.

16 Advierte DÍAZ Y GARCÍA CONLLEDO, en: LH Valle Muñiz, 2001, 220 ss.; Error elementos normativos del tipo, 2008, 192 n. 5, que de las dos expresiones, error de hecho o error de tipo, ninguna es más preferible respecto de la otra: en el caso del error de tipo, resulta ambiguo qué se quiere expresar con este término, ya que puede hacer pensar que se trata de un error sobre la interpretación del tipo legal, cuando lo que se quiere significar con aquella expresión (error de tipo) es el desconocimiento de la concurrencia de aquellas circunstancias que han sido seleccionadas por la ley para describir una infracción penal. En el caso del error de hecho, tampoco ésta es la terminología más correcta, porque en la misma se pueden incluir errores que se desconectan totalmente del contenido del tipo penal (y pone como ejemplo, el error sobre la identidad de la víctima en el delito de homicidio). Concluye este autor que hubiera sido más acertada la utilización de otras expresiones para hacer referencia a lo que la doctrina ha venido denominando error de tipo, poniendo como ejemplo las expresiones "circunstancia", o "elemento".

17 Esta interpretación del término "hecho" en el art. 14.1 CP español es la que propone LUZÓN PEÑA, PG, I, 1996, 449. Admite esta interpretación MARTÍNEZ-BUJÁN PÉREZ, DP económico. PG, 2a , 2007, 412. Por su parte, DÍAZ Y GARCÍA CONLLEDO, en: LH Valle Muñiz, 2001, 217 ss.; Error elementos normativos del tipo, 2008, 195 ss., sin descartar la interpretación que plantea LUZÓN PEÑA (u otros autores como MIR PUIG al que se ha hecho referencia n. 14) sobre el término "hecho" en el art. 14.1 CP español, propone otra interpretación de este concepto, conectada en parte con aquellas otras interpretaciones: con la palabra "hecho" del art. 14.1 CP español se quiere poner de relieve que el sujeto se equivoca sobre lo que hace, sobre las circunstancias de su propio hecho, no sabe que mata o no sabe que toma cosa mueble ajena. Añade DÍAZ Y GARCÍA CONLLEDO que, desde la Filosofía analítica, con el término "hecho" se hace referencia tanto a hechos institucionales (sociales, jurídicos) como a hechos naturales, por lo que no habría ningún obstáculo en incluir en el término "hecho" del art. 14.1 CP español el error sobre los elementos normativos del tipo (cuando tal error suponga desconocimiento de las circunstancias o elementos de la infracción penal). 
de esta forma el error sobre el hecho constitutivo de la infracción penal o error de tipo puede consistir en el desconocimiento sobre la situación fáctica (sea que se trate de un elemento descriptivo, sea que se trate de un elemento normativo) y/o en el desconocimiento del significado material auténtico de los elementos normativos del tipo ${ }^{18}$.

\title{
La regulación del CP nicaragüense, distinguiendo entre el error de tipo y el error de prohibición, con diferentes efectos en uno y otro caso, coincide con las reformas producidas en el Derecho Comparado desde mediados del S. XX en los países europeos e iberoamericanos ${ }^{19}$.
}

\begin{abstract}
Se distingue entre el error de tipo, esto es, el desconocimiento de la concurrencia de un elemento fundamentador de la prohibición legal de la conducta ${ }^{20}$ y el error de prohibición, esto es, el sujeto conoce todos los elementos fundamentadores o presupuesto de la prohibición pero desconoce la valoración negativa y prohibición jurídica de su conducta ${ }^{21}$ :
\end{abstract}

18 Ésta es la postura defendida por DÍAZ Y GARCÍA CONLLEDO, en: LH Casabó, I, 1997, 676 ss. [= en: LUZÓN PEÑA/MIR PUIG (Coords.), Cuestiones actuales de la teoría del delito, 1999, 80 ss.]; en: LH Valle Muñiz, 2001, 210 ss; Error sobre elementos normativos del tipo, 2008, 315-424, en relación con el error de tipo cuando el mismo recae sobre los elementos normativos del tipo penal. Admite esta interpretación, LUZÓN PEÑA, PG, I, 1996, 449 s.; en: EPB, 2002, 659. Para más detalles sobre las posturas doctrinales defendidas en torno al conocimiento necesario de los elementos normativos del tipo a efectos de plantear el dolo respecto de estos elementos, y distinguir así entre el error de tipo y el error de subsunción (considerado este segundo a veces como error irrelevante, a veces podrá dar lugar a un error de prohibición, a veces se tratará de un error de prohibición penal, y en ocasiones tal error de subsunción podrá excluir el conocimiento del significado material auténtico del elemento normativo, por lo que debe ser tratado como un error de tipo), ampliamente, DÍAZ Y GARCÍA CONLLEDO, en: LH Casabó, I, 1997, 658 ss., 676 ss. [= en: LUZÓN PEÑA/MIR PUIG (Coords.), Cuestiones actuales de la teoría del delito, 1999, 61 ss., 80 ss.]; en: LH Valle Muñiz, 2001, 210 ss.; Error elementos normativos del tipo, 2008, 189-424.

19 Así, y por citar sólo algunos ejemplos, en relación con el DP europeo: en el StGB alemán se distingue entre el error de tipo y el error de prohibición ( $\S 16$ y 17$)$, aunando diferentes efectos a una y otra clase de error, y admitiendo la atenuación facultativa de la pena en el error vencible de prohibición; en el CP portugués se diferencia entre el error de tipo y el error de prohibición (arts. 16 y 17), se reconoce expresamente la teoría de la culpabilidad en la regulación de esta segunda clase de error, admitiendo la atenuación facultativa de la pena en el error vencible de prohibición. Por su parte, en el anterior CP español de 1944/1973 y en el vigente CP de 1995 también se diferencia entre el error de tipo y el error de prohibición (arts 6 bis a y 14 respectivamente), con diferentes efectos en uno y otro caso, y se ha establecido la atenuación obligatoria de la pena en el error vencible de prohibición. Y en el DP latinoamericano se ha seguido en algunos casos claramente el sistema alemán en el tratamiento del error vencible de prohibición: así ha sucedido en el CP brasileño, en el CP colombiano, en el CP costarricense (arts. 34 y 35) y en el PCP costarricense (arts. 25 y 32). Pero en otros CP se ha seguido el sistema español de atenuación obligatoria de la pena en el error vencible de prohibición: es el caso, por ejemplo, del CP mexicano (art. 66), y el CP peruano (art. 14.2).

20 Esta definición del error de tipo es propuesta por LUZÓN PEÑA, en: EJB, II, 1995, 2838; PG, I, 1996, 440; en: EPB, 2002, 656. Una definición más simplificada plantea DÍAZ Y GARCÍA CONLLEDO, en: LH Casabó, I, 1997, 673 [= en: LUZÓN PEÑA/MIR PUIG (Coords.), Cuestiones actuales de la teoría del delito, 1999, 76]; Error elementos normativos del tipo, 2008, 149: el error de tipo es el error que recae sobre la concurrencia en el hecho de un elemento que pertenece al tipo objetivo del delito.

21 Definición propuesta por LUZÓN PEÑA, en: EJB, II, 1995, 2843; PG, I, 1996, 462; en: EPB, 2002, 661; y admitida por DÍAZ Y GARCÍA CONLLEDO, en: LH Casabó, I, 1997, 673 [= en: LUZÓN PEÑA/MIR PUIG (Coords.), Cuestiones actuales de la teoría del delito, 1999, 76]; Error elementos normativos del tipo, 2008, 159; OLAIZOLA NOGALES, El error de prohibición. Especial atención a los criterios para su apreciación y para la determinación de su vencibilidad e invencibilidad, La Ley, Madrid, 2007, 53. Una definición muy similar propone MIR PUIG, en: COBO DEL ROSAL (dir.), Comentarios CP, I, 1999, 658; PG, 8 , 2008, 546: el sujeto realiza la situación típica, conociéndola correctamente, pero desconoce que tal conducta está prohibida por el Derecho. 
el primero excluye el dolo, y si es invencible, también la imprudencia; el segundo atenúa la responsabilidad penal, y si es invencible, la excluye.

\begin{abstract}
En la ya tradicional discusión entre las denominadas teorías del dolo ${ }^{22}$ y de la culpabilidad ${ }^{23}$ el CP nicaragüense parece haber optado por la teoría de la culpabilidad, pues, en principio, sólo desde esta tesis se puede defender, en primer lugar, el distinto tratamiento entre el error de tipo y el error de prohibición y, en segundo lugar, que el error de prohibición no excluya el dolo sino que tan solo afecte a la culpabilidad, atenuándola o excluyéndola según que el error sea vencible o invencible ${ }^{24}$. Y como un argumento adicional para el reconocimiento dela teoría de la culpabilidad puede señalarse la decisión del CP nicaragüense de regular de forma expresa y diferenciada los principios de responsabilidad subjetiva y de culpabilidad (art. $9 \mathrm{CP}$ nicaragüense).
\end{abstract}

\title{
Ahora bien, el distinto tratamiento de los errores de tipo y de prohibición en el CP nicaragüense también puede interpretarse desde la teoría limitada o modificada del dolo ${ }^{25}$, en el mismo sentido que propone un
}

22 La teoría del dolo es la defendida por la doctrina tradicional, y según esta tesis el error de prohibición también excluye el dolo, ya que éste se concibe como dolus malus (subjetivamente malo) y requiere el conocimiento de la antijuridicidad, siendo el dolo una forma o elemento de la culpabilidad. Según la teoría del dolo, tanto el error de tipo como el error de prohibición producen el mismo efecto: si es vencible excluye el dolo y deja subsistente la imprudencia, y si es invencible se excluye la responsabilidad penal por falta de dolo y de imprudencia. Para más detalles sobre esta teoría, por todos, LUZÓN PEÑA, en: EJB, II, 1995, 2844; PG, I, 1996, 465; en: EPB, 2002, 662; CEREZO MIR, Curso de DP español. PG III. Teoría jurídica del delito/2, Tecnos, Madrid, 2004, 118 ss.; ZUGALDÍA ESPINAR, en: ZUGALDİA ESPINAR (dir.)/PÉREZ ALONSO (coord.), PG, 2ª 2004,615 s.; BUSTOS RAMÍREZ/HORMAZABAL MALARÉE, PG, 2a , 2006, 472 ss.; ROXIN, AT, I, 4ª , 2006, 927 ss. (= PG, I, 1997, 861 ss.); MIR PUIG, PG, 8, 2008, 547.

23 Para la teoría de la culpabilidad el error de prohibición no excluye el dolo, pues éste ya no exige conciencia de la antijuridicidad, sino que aquel error afecta sólo a la culpabilidad, excluyéndola si el error es invencible o atenuándola si es vencible. Además, el dolo ya no es una forma o elemento de la culpabilidad, sino que, atendiendo a diversas argumentaciones, ha pasado a ser explicado como un elemento del tipo (o del tipo global de injusto según los partidarios de la teoría de los elementos negativos del tipo). Para más detalles sobre esta teoría, por todos, LUZÓN PEÑA, en: EJB, II, 1995, 2844; PG, I, 1996, 466 s.; en: EPB, 2002, 661; CEREZO MIR, PG, III/2, 2004, 121 ss.; ZUGALDÍA ESPINAR, en: ZUGALDÍA ESPINAR (dir.)/PÉREZ ALONSO (coord.), PG, 2 ${ }^{\mathrm{a}}$, 2004, 612 s.; BUSTOS RAMÍREZ/HORMAZÁBAL MALARÉE, PG, 2ª 2006, 474 ss.; ROXIN, AT, I, 4 2006, 929 ss. (= PG, I, 1997, 861 ss.); MIR PUIG, PG, 8 $8^{\text {a }}, 2008,548$ s.

24 A tal conclusión ha llegado la doctrina española mayoritaria en la interpretación del art. 14 CP español. Vid., por todos, LUZÓN PEÑA, en: EJB, II, 1995, 2844; PG, I, 1996, 465 ss.; en: EPB, 2002, 662 s.; DÍAZ Y GARCÍA CONLLEDO, en: LH Casabó, I, 1997, 675 [= en: LUZÓN PEÑA/MIR PUIG (Coords.), Cuestiones actuales de la teoría del delito, 1999, 79]; en: LH Torío, 1999, 340 n. 15; Error elementos normativos del tipo, 2008, 166, 173, atendiendo fundamentalmente a consideraciones de índole dogmática y político criminal; BACIGALUPO ZAPATER, PG, 5a , 1998, 310; CEREZO MIR, PG, III/2, 2004, 129 ss.; BERDUGO GÓMEZ DE LA TORRE/ ARROYO ZAPATERO/FERRÉ OLIVÉ/GARCÍA RIVAS/SERRANO PIEDECASAS/TERRADILLOS BASOCO, PG, 2004, 346 s.; ARIAS EIBE, Error en DP, 2007, 87 s.; DÍEZ RIPOLLÉS, PG, 2007, 437; OLAIZOLA NOGALES, Error de prohibición, 2007, 46 s. Y a esta misma conclusión se ha llegado en la interpretación del $\S$ 17 StGB alemán. Vid., para más detalles, por todos, ROXIN, AT, I, 4ª , 2006, 929 ss. (= PG, I, 1997, 863 ss.).

25 La teoría limitada del dolo admite que tanto el dolo como la imprudencia son formas o elementos de la culpabilidad, y que el dolo se compone de conocimiento de los elementos objetivos del tipo y conocimiento de la antijuridicidad o prohibición jurídica de la conducta. Pero los defensores de esta teoría introducen restricciones en la exigencia del conocimiento o conciencia de la antijuridicidad, pues ya no es necesario que el sujeto tenga conocimiento actual ni exacto de la antijuridicidad, basta con el conocimiento potencial o actualizable y aproximado sobre la misma. Y en todo caso se descarta el error de prohibición cuando el desconocimiento o error revela ceguera jurídica u hostilidad hacia el Derecho. Una segunda restricción planteada por los partidarios de esta teoría afecta 
sector de la doctrina española en la interpretación del art. 14 CP español ${ }^{26}$, ofreciendo al respecto los siguientes argumentos: en primer lugar, la teoría limitada del dolo reconoce que el error vencible de tipo y el error vencible de prohibición no pueden ser tratados de forma equivalente, ya que el segundo es menos excusable que el primero, y ello exige que en un ordenamiento jurídico que opte por el sistema de numerus clausus en la incriminación de los delitos imprudentes (como es el CP español -art. 12 de este texto legal- y el CP nicaragüense -art. 22 de este texto punitivo-) el error de prohibición vencible debe recibir un tratamiento diferente, castigando de forma generalizada la imprudencia de Derecho a través de una cláusula general de determinación de la pena de esta clase de imprudencia. En segundo lugar, y conectado con lo anterior, en la regulación del error de prohibición en ningún momento el legislador ha declarado expresamente que tal clase de error excluya el dolo, tan solo se establece que la pena está atenuada o excluida según el error sea vencible o invencible, por lo que no existe ningún impedimento para interpretar tal regulación desde la teoría del dolo entendiendo que la atenuación de la pena en el error vencible de prohibición supone la introducción de la mencionada cláusula de incriminación generalizada de la imprudencia de Derecho. En tercer lugar, para la teoría de la culpabilidad, al menos desde su planteamiento originario por la concepción finalista del delito, el dolo es un elemento del tipo, definido como dolo natural, esto es,

al tratamiento diferenciado del error de tipo y el error de prohibición en aquellos ordenamientos jurídicos en los que se castiga excepcionalmente el delito imprudente, ya que se considera que el error vencible de prohibición o la imprudencia de Derecho debe castigarse en todo caso, si bien con una pena menor que la conducta dolosa, atenuación de la pena que se consigue con la introducción de una cláusula de determinación de la pena general para la imprudencia de Derecho o error de prohibición vencible. Para más detalles sobre esta teoría, vid., por todos, LUZÓN PEÑA, en: EJB, II, 1995, 2844; PG, I, 1996, 465; en: EPB, 2002, 662.

26 Admiten la posibilidad de interpretar el art. 14 CP español desde los postulados tanto de la teoría del dolo como de la teoría de la culpabilidad, entre otros, DÍAZ Y GARCÍA CONLLEDO, en: LH Torío, 1999, 340 n. 15, 349; Error elementos normativos del tipo, 2008, 166 s., 173; ZUGALDÍA ESPINAR, en: COBO DEL ROSAL (dir.), Comentarios CP, I, 1999, 694 s.; MARTÍNEZ-BUJÁN PÉREZ, DP económico. PG, 2a , 2007, 401 s., aunque estos autores acaban optando por la teoría de la culpabilidad atendiendo a consideraciones de carácter dogmático y políticocriminales (así, ZUGALDÍA ESPINAR ofrece los siguientes argumentos que, en su opinión, convierten a la teoría de la culpabilidad en la más correcta: en primer lugar, porque si el error de prohibición excluyera el dolo la condena no produciría antecedentes penales por delito doloso, lo que es poco correcto dada la mayor gravedad del comportamiento de quien actúa con error vencible de prohibición del que lo hace con error vencible de tipo, y esto tiene efectos en la suspensión de la pena privativa de libertad, ya que la condena anterior por delito imprudente no se tiene en cuenta para decidir la suspensión de la pena -la misma regulación en torno a la suspensión de la pena de prisión se ha previsto también en el art. 88.a CP nicaragüense-; y en segundo lugar, con la teoría de la cláusula de la culpa iuris se corre el peligro de entender que la atenuación de la pena del art. 14.3 CP español -y el correspondiente art. 26 CP nicaragüense- para el error vencible de prohibición sólo procede respecto de delitos punibles en su modalidad imprudente); en: ZUGALDÍA ESPINAR (dir.)/PÉREZ ALONSO (coord.), PG, 2a , 2004, 611 s., 616. Aunque la mayoría de la doctrina española defiende la teoría de la culpabilidad, un sector minoritario de la doctrina, entre los que cabe citar a COBO DEL ROSAL/VIVES ANTÓN, PG, 5ª 1999 , 681 s.; OLMEDO CARDENTE, en: COBO DEL ROSAL (dir.), Comentarios CP, II, 1999, 568 ss. Y MIR PUIG, en: COBO DEL ROSAL (dir.), Comentarios CP, I, 1999, 658 s., 677 s.; PG, 8 ${ }^{\text {a }, ~ 2008, ~} 552$ ss., 558 s., se muestra partidario de la teoría limitada del dolo, aunque la teoría que defiende MIR PUIG no coincide con la tradicional teoría limitada del dolo, considerando que el dolo es una forma o elemento de la culpabilidad, sino que para este autor el dolo ha de ser entendio como dolo subjetivamente malo, porque exige conocimiento de los elementos del tipo y el conocimiento de la antijuridicidad, y tal elemento forma parte del tipo de injusto, no de la culpabilidad. 
como el conocimiento (y voluntad) de realizar los elementos objetivos del tipo, y se extrae de él el conocimiento de la antijuridicidad, que se mantiene como un requisito autónomo de la culpabilidad, pero bastando con el conocimiento potencial de la antijuridicidad para la plena responsabilidad penal, no exigiendo el conocimiento actual de la antijuridicidad. Sin embargo, en el CP nicaragüense, al igual que el $\mathrm{CP}$ español, se exige para la plena responsabilidad penal que el sujeto tenga conocimiento actual sobre la antijuridicidad, conocimiento que ha sido requerido siempre desde la teoría del dolo ${ }^{27}$. Y en cuarto lugar, y como consecuencia de lo anterior, para la teoría de la culpabilidad la vencibilidad del error de prohibición no significa atenuación obligatoria dela pena, sino tan solo una atenuación facultativa, porquela culpabilidad del sujeto no necesariamente ha de estar disminuida en estos casos (por ejemplo, en los supuestos de errores burdos) ${ }^{28}$. En consecuencia, si en el error de prohibición vencible es obligatoria la atenuación de la pena, como sucede en el CP español y en el CP nicaragüense, y se exige conocimiento actual y no sólo potencial de la antijuridicidad, ello sólo puede ser explicado desde el reconocimiento de que estamos ante una imprudencia de Derecho y, por tanto, ante la regulación del error de prohibición siguiendo el planteamiento de la teoría (limitada) del dolo ${ }^{29}$.

27 Para más detalles sobre este argumento, MIR PUIG, PG, 8 8 , 2008, 559.

28 Vid., sobre este argumento a favor de la teoría limitada del dolo, atendiendo a que también el error burdo sería relevante, conclusión a la que no se llegaría desde la teoría de la culpabilidad, MIR PUIG, PG, 8, $2008,559$. Más adelante, al referirnos al error de prohibición, volveremos sobre la relevancia o no del denominado error burdo. De todas formas, frente a los dos últimos argumentos expuestos en el texto, un autor claramente partidario de la teoría de la culpabilidad (por defender la teoría finalista de acción, tesis doctrinal que ha defendido a ultranza esta teoría en el tratamiento del error de prohibición) como CEREZO MIR, DPPG (Lecciones 26-40), Universidad Nacional de Educación a Distancia, Madrid, 1997, 81; PG, III/2, 2004, 129 ss, refiriéndose al CP español, ha valorado positivamente la decisión de atenuar obligatoriamente la pena en el error de prohibición vencible, y ello desde las siguientes consideraciones dogmáticas y políticocriminales: en primer lugar, porque en los supuestos de error de prohibición, aunque fuera muy fácilmente vencible, el sujeto creía que su conducta era lícita, y por ello su capacidad de obrar de otro modo estaba disminuida; la culpabilidad es menor, por lo que la atenuación debe ser obligatoria, porque ésta es la más ajustada al principio de culpabilidad. Y en segundo lugar, porque si la atenuación de la pena en el error vencible de prohibición fuera facultativa nos encontraríamos con el peligro de que los Tribunales volvieran a aplicar de modo solapado el principio error iuris nocet, no tomando en consideración la atenuante.

29 Ahora bien, si somos rigurosos en la apreciación de las explicaciones de la teoría limitada del dolo, tampoco la regulación del CP nicaragüense podría ser explicada desde los postulados de esta teoría, y ello por lo siguiente. Originariamente, y tal y como resume LUZÓN PEÑA, en: EJB II, 2005, 2844; PG, I, 1996, 465; en: EPB, 2002, 662 , la teoría limitada del dolo fue planteada por sus defensores como una restricción a las consecuencias a las que se llegaba con la teoría estricta del dolo en un sistema de incriminación cerrada y excepcional de los delitos imprudentes: si se exigía conciencia actual de la antijuridicidad, y aunque el error de prohibición fuera fácilmente vencible o incluso en ocasiones burdo, tal error llevaba a la injustificada solución de la impunidad del comportamiento en todos aquellos casos en los que el legislador había optado por no castigar la conducta imprudente. Para evitar estas lagunas de punibilidad, los partidarios de la teoría del dolo proponen restricciones a su fundamentación, surgiendo de este modo la teoría limitada del dolo: en primer lugar, no es necesario conocimiento actual de la antijuridicidad, basta con conocimiento actualizable de la misma para la plena responsabilidad por el delito doloso (pero, como veremos en el apartado relativo al error de prohibición, el art. 26 CP nicaragüense exige conocimiento actual de la antijuridicidad para afirmar la plena responsabilidad penal); en segundo lugar, 


\title{
3. El error de tipo: art. 25 CP nicaragüense
}

\author{
Como se ha mencionado líneas atrás, el error de tipo se puede definir \\ como el desconocimiento (por error o por ignorancia) sobre un elemento \\ del tipo objetivo, o más exactamente, como el desconocimiento de los \\ elementos fundamentadores de la prohibición legal de la conducta ${ }^{30}$.
}

\begin{abstract}
En el CP nicaragüense se diferencia entre el error sobre un hecho constitutivo de la infracción penal y el error sobre un hecho cualificador de la infracción penal o sobre una circunstancia agravante (al igual que sucede en el CP español). Y a su vez, en cada una de estas clases de error se distingue entre el error vencible y el error invencible.
\end{abstract}

\section{Por hecho constitutivo de la infracción penal hemos de entender aquellos elementos fundamentadores de la correspondiente modalidad delictiva, los elementos que fundamentan la prohibición de la conducta. Ejemplo, en el delito de homicidio, desconocer que se está realizando la acción de matar a una persona viva por creer que a quien se dispara es un animal o que se dispara sobre un cadáver, o en el delito de hurto, desconocer que la cosa mueble de la que se apropia el sujeto es ajena, por haberla confundido con una cosa mueble que le pertenece ${ }^{31}$.}

no es admisible el error de prohibición cuando éste se basa en un error burdo o en clara hostilidad o enemistad hacia el Derecho (y, sin embargo, como veremos en el epígrafe relativo al error de prohibición, el CP nicaragüense parece admitir efectos atenuantes de la responsabilidad penal también para el error burdo o basado en ceguera jurídica); y en tercer lugar, el error vencible de prohibición no puede tener las mismas consecuencias que el error vencible de tipo, el primero debe ser castigado en todo caso, si bien con una atenuación obligatoria de la pena por cuanto el sujeto ha cometido una imprudencia de Derecho (sólo este último argumento podría ser aplicado en la interpretación del art. $26 \mathrm{CP}$ nicaragüense).

30 Vid., para más detalles, LUZÓN PEÑA, en: EJB, II, 1995, 2838; PG, I, 1996, 440 s.; en: EPB, $2002,655$.

31 A través de estas reglas relativas al error de tipo se van a resolver los denominados supuestos especiales de error de tipo: los casos de error in personam (sobre el que volveremos más adelante), la aberratio ictus, el error sobre el curso causal y el dolus generalis, si bien es preciso advertir que en estos supuestos problemáticos se van a plantear previamente otras cuestiones relacionadas con el tipo objetivo (básicamente, problemas relacionados con la imputación objetiva, forma de concebir el bien jurídico protegido). Brevemente, los supuestos especiales de error de tipo consisten en lo siguiente: en el error sobre el objeto o la persona, el sujeto se equivoca sobre la identidad del objeto sobre el que recae la acción o sobre la identidad de la persona sobre la que recae la acción (y en su tratamiento jurídicopenal habrá que distinguir entre aquellos casos en los que el error sobre la identidad de la víctima no implica un cambio en la calificación jurídica de la conducta, en cuyo caso sería un error irrelevante, y el error que sí produce un cambio en la calificación jurídica de la conducta, y en este caso habrá que diferenciar entre errores directos y errores inversos); la aberratio ictus, se produce una desviación o modificación del curso causal previsto por el autor lo que hace que su acción no alcance el objeto (ni al bien jurídico que representa dicho objeto) que se había representado y quería, sino que alcanza a otro objeto (y otro bien jurídico representado por ese objeto) distinto y más o menos próximo al primero (ejemplo, el sujeto $\mathrm{X}$ dispara a la víctima $\mathrm{V}$ con ánimo de matar, pero el disparo se desvía y alcanza a Z, que se encontraba detrás de $\mathrm{V}$, o al lado de $\mathrm{V}$, o alcanza a $\mathrm{Z}$ porque en el momento en que dispara el autor $\mathrm{Z}$ se coloca en la trayectoria de la bala). En el error sobre el curso causal el sujeto se equivoca sobre el curso que realmente sigue el acontecer típico, si bien su acción alcanza finalmente al objeto (y al bien jurídico que está representado por dicho objeto) que se había representado y quería el autor. Ejemplos, el sujeto X quiere matar a su víctima V de una puñalada; no acierta en un órgano vital, pero de todas formas $\mathrm{V}$ muere porque el puñal utilizado está impregnado de una 
Por hecho que califique la infracción penal hemos de entender aquellas circunstancias que, partiendo de un tipo básico (que son los que contienen los elementos fundamentadores de una determinada conducta delictiva), sirven para la configuración de los delitos derivados ${ }^{32}$. A la vista de la equiparación entre hecho que califique la infracción o sobre una circunstancia agravante, ha de interpretarse que en esta modalidad de error se ha querido hacer referencia solamente a los tipos cualificados agravados. En el caso de error sobre el hecho que califique la infracción, la particularidad estriba en que el error afecta únicamente al elemento cualificador, pero el sujeto conoce perfectamente los elementos o circunstancias que fundamentan el tipo básico. Ejemplos de tipos cualificados serían el delito de hurto de un bien cultural (art. 220.f. CP nicaragüense) y el error sobre el elemento cualificador se planteará cuando el sujeto se apodera de cosa mueble desconociendo que se trata de un bien cultural, pero sabiendo que la cosa de la que se apodera es ajena y que no cuenta con el consentimiento de su dueño, o el delito de daños agravado por tratarse de una cosa de valor científico, artístico, cultural, religioso o histórico (art. 244.1.b. CP nicaragüense), y el error sobre el elemento cualificador consistirá en destruir cosa mueble o inmueble ajena sin saber que posee ese valor ${ }^{33}$.

sustancia venenosa, circunstancia que desconocía X (y que puede o no ser previsible, dependiendo del lugar donde se guardara el cuchillo: en un almacén de tóxicos, en la cocina de la víctima). O el sujeto X quiere matar a $\mathrm{V}$ de un disparo en el corazón, pero la bala alcanza a otro órgano vital, y la víctima muere igualmente. En el dolus generalis el sujeto realiza una primera acción con el conocimiento y voluntad de realizar el hecho típicamente antijurídico, pero en realidad no consigue su objetivo. Creyendo el sujeto que ya ha cometido el delito lleva a cabo una segunda acción con la que consigue, sin saberlo ni pretenderlo, realizar el hecho típico. Ejemplo, el sujeto X dispara contra V con dolo de matar, y creyendo que lo ha matado (porque V está tendido en el suelo, sangrando por la herida, inmóvil e inconsciente) decide ocultar el cadáver, enterrándolo, y ahora, con esta segunda acción es cuando X, sin saberlo ni pretenderlo (él cree que entierra a un cadáver) mata a la víctima $\mathrm{V}$. Estas clases especiales de error de tipo han ocupado gran parte de la atención de la doctrina científica, planteándose soluciones muy diversas en los distintos supuestos. Para más detalles, vid., entre otros, SILVA SÁNCHEZ, 'Aberratio ictus' e imputación objetiva, en: ADP 1984, 347 ss.; LUZÓN PEÑA, PG, I, 1996, 433 ss., 453 ss.; en: EPB, 2002 , 660 s.; RODRÍGUEZ MOURULLO, en: RODRÍGUEZ MOURULLO (dir.)/JORGE BARREIRO (coord.), Comentarios CP, 1997, 67 s.; BACIGALUPO ZAPATER, PG, 5a, 1998, 235 ss.; CEREZO MIR, PG, II, 6ª 1998, 136 ss.; COBO DEL ROSAL/VIVES ANTÓN, PG, 5a , 1999, 662 ss.; BERDUGO GÓMEZ DE LA TORRE/ARROYO ZAPATERO/FERRÉ OLIVÉ/GARCÍA RIVAS/SERRANO PIEDECASAS/TERRADILLOS BASOCO, PG, 2004, 260; RAMOS TAPIA, en: ZUGALDÍA ESPINAR (dir.)/PÉREZ ALONSO (coord.), PG, 2a , 2004,521 ss.; BUSTOS RAMÍREZ/HORMAZÁBAL MALARÉE, PG, 2a , 2006, 370 s.; ROXIN, AT, I, 4 , 2006, 509 ss. (= PG, I, 1997, 487 ss.); DÍEZ RIPOLLÉS, PG, 2007, 176 ss.; MUÑOZ CONDE/GARCÍA ARÁN, PG, 7ª , 2007, 276 s.; MIR PUIG, PG, $8^{\mathrm{a}}, 2008,274$ ss.

32 Los tipos derivados pueden clasificarse a su vez en tipos derivados en sentido estricto (porque siguen siendo tipos dependientes del delito o tipo básico, y por ello los elementos adicionales son considerados elementos típicos accidentales) y tipos autónomos. Y dentro de los primeros cabe distinguir entre los tipos derivados cualificados o agravados, cuando los elementos adicionales sirven para agravar la responsabilidad penal por un mayor desvalor de acción y/o de resultado, y tipos derivados privilegiados, cuando los elementos añadidos sirven para una atenuación de la responsabilidad penal por una atenuación del injusto (del desvalor de acción y/o de resultado) o de la culpabilidad. Para más detalles sobre estas clases de tipos penales, LUZÓN PEÑA, PG, I, 1996, 318 s.

33 Como cuestión previa a analizar en relación con el error sobre el hecho que califica la infracción penal ha de plantearse la verdadera naturaleza del delito derivado que se formula con la utilización de tal circunstancia cualificadora, esto es, si se trata de un tipo cualificado agravado o de un delito autónomo, ya que el tratamiento del 


\section{Cuando el error sólo afecta al elemento cualificador resulta irrelevante si el mismo es vencible o invencible, en cualquier caso la solución es no}

error sobre la circunstancia "cualificadora" puede ser diferente en uno u otro caso: porque si se trata de un elemento "cualificador" de un delito autónomo tal circunstancia pasa a ser en realidad un elemento cofundamentador de tal delito, por lo que el tratamiento del error sobre la misma debe regirse según lo dispuesto en el art. $25.1 \mathrm{CP}$ nicaragüense, mientras que si se trata en puridad de un elemento cualificador de un auténtico delito cualificado agravado, en tal caso el error sobre tal circunstancia sí está sometida a las reglas del art. 25.2 CP nicaragüense. Esta cuestión puede ser analizada a través del delito de parricidio (art. 139 CP nicaragüense) y su relación con el delito de homicidio (art. $138 \mathrm{CP}$ nicaragüense): si se considera que el parricidio es un delito autónomo entonces la relación de parentesco entre autor y víctima es un elemento cofundamentador de la infracción penal (junto con los requisitos de la acción típica, matar, y el sujeto pasivo-objeto material, a otro), por lo que el error sobre la relación de parentesco entre autor y víctima, desconocer que se mata a un ascendiente, descendiente, hermano, cónyuge o conviviente en unión de hecho estable, habría de ser analizado según lo dispuesto en el art. 25.1 CP nicaragüense: si el error es vencible dará lugar, en su caso, a responsabilidad penal por delito imprudente, lo que no sucede en este caso porque no se ha tipificado el delito de parricidio imprudente, y si el error es invencible se excluye la responsabilidad penal. Por el contrario, si se considera que el delito de parricidio es un delito derivado cualificado o agravado del delito de homicidio, en tal caso la relación de parentesco entre autor y víctima no es un elemento cofundamentador o esencial de la infracción penal, es una mera circunstancia típica "accidental" cualificadora o agravante, por lo que el error sobre tal circunstancia habrá de ser sometida a las reglas del art. 25.2 CP nicaragüense: el error excluye la responsabilidad penal por el tipo cualificado, quedando subsistente la responsabilidad penal por el delito básico, en este caso por el delito de homicidio doloso, ya que respecto de los elementos cofundamentadores del tipo (matar a otro), éstos sí han sido abarcados por el dolo del autor. Más tajante aún sobre estas cuestiones, GRACIA MARTÍN, en: DÍEZ RIPOLLÉS/GRACIA MARTÍN (Coords.), Comentarios al CP. Parte Especial, tomo I, Títulos I a VI y faltas correspondientes, Tirant lo Blanch, 1997, 34 s., quien ha afirmado que las circunstancias agravantes y atenuantes que sirven para formar tipos agravados y privilegiados de uno básico son elementos constitutivos de aquellos tipos y no meras circunstancias modificativas de la responsabilidad penal, y deberán estar sometidos en todo al régimen del tratamiento jurídicopenal de los elementos del tipo o, en su caso, al del elemento de la figura de delito en que se insertan, pero en ningún caso puede ser sometido al tratamiento de las circunstancias. Para este autor, estos elementos pierden su carácter de circunstancias y con ello pasan a someterse al régimen de los elementos esenciales del delito, en concreto, si se trata de elementos de lo injusto, se someten al régimen dogmático de la tipicidad con todas las consecuencias en materia de error, la participación y el concurso. De todas formas, creo que la solución del tratamiento del error en los delitos derivados y autónomos no es tan sencilla como a primera vista pudiera parecer, pues como paso previo será necesario establecer claramente qué relación concusal existe entre el tipo básico y el tipo derivado y el autónomo, si es una relación de exclusión o de subsidiariedad/especialidad. Así, en el delito de parricidio, sea que se entienda como delito cualificado agravado, sea que se entienda como delito autónomo, es preciso averiguar la relación que plantea con el delito básico de homicidio, esto es, si en el delito de homicidio se incluye o no en el término "otro" a los parientes del sujeto activo: si se responde afirmativamente, los parientes del sujeto activo también están incluidos en la expresión "otro" del delito de homicidio, entonces en el error sobre la relación de parentesco (el sujeto no sabe que mata a uno de los parientes mencionados en el art. 139 CP nicaragüense) la solución definitiva será la apreciación del delito de homicidio doloso consumado, porque el sujeto activo sí sabe que mata a otro consciente y voluntariamente, aplicándose el tipo básico de forma subsidaria (pues el tipo cualificado o autónomo de parricidio será ley especial frente al homicidio cuando se cumplan todos los elementos, objetivos y subjetivos, del art. $139 \mathrm{CP}$ nicaragüense). Pero si la respuesta fuera negativa, y se concluyera que el delito de homicidio se ha redactado recurriendo al principio de exclusión en relación con el delito de parricidio, esto es, en el delito de homicidio sólo se castiga la conducta de matar a otro siempre que el otro no sea un determinado pariente del sujeto activo, entonces el error sobre la relación de parentesco (el autor quiere matar a una persona extraña, y no sabe que mata a su padre) tendría que llevar a la conclusión, a todas luces injustificada, de excluir, en primer lugar, la responsabilidad penal por el delito de parricidio, ya que el dolo del sujeto no abarca la circunstancia relativa a la relación de parentesco que le une con la víctima, pero en segundo lugar, también habría que excluir la responsabilidad penal por el delito de homicidio doloso (consumado), ya que el hecho cometido tampoco encajaría en el delito de homicidio, ya que en éste sólo pueden ser sujetos pasivos las personas que no tengan una determinada relación parental con el sujeto activo; a lo sumo se podrá castigar al sujeto por su intención, pues ha intentado matar a un extraño, por tanto, ipor una tentativa inidónea de homicidio! (conclusión a todas luces injustificada). En otro orden de cosas, desde esta perspectiva del error sobre las circunstancias esenciales/error sobre los elementos típicos accidentales cualificantes (y teniendo en cuenta las relaciones concursales entre los tipos básicos/tipos derivados, cualificados y/o autónomos) se deberán resolver los casos de errores (directos) in persona o in obiecto cuando tal error sea relevante (cuando se desconoce una cualidad del objeto o de la persona sobre la que recae la acción en virtud de la cual el bien jurídico representado por tal objeto o persona tiene una protección penal más intensa, o a veces se ve afectado otro bien jurídico, y el dolo del sujeto no abarca tal cualidad que dará lugar al tipo agravado o al tipo autónomo). Para más detalles sobre la solución al error (directo) en el objeto o en la persona, cuando tal error sí da lugar a un cambio en la calificación jurídica de la conducta (porque, sin saberlo el sujeto, está cometiendo un delito cualificado o autónomo), por todos, LUZÓN PEÑA, PG, I, 1996, 455 s. 
apreciar el elemento cualificador; en los dos ejemplos planteados, sea el error vencible o sea invencible, en ambos casos resultan inaplicables los tipos agravados de hurto y daños, siendo aplicables los tipos básicos de hurto (art. 219 CP nicaragüense) y de daños (art. 243 CP nicaragüense), ya que respecto de los elementos típicos de estas dos modalidades delictivas el sujeto no actuaría con error o ignorancia.

Como se acaba de mencionar, en el art. 25.2 CP nicaragüense también se regula de forma expresa el error sobre una circunstancia agravante, es decir, sobre alguna de las circunstancias modificativas genéricas descritas en los arts. 36 y $37 \mathrm{CP}$ nicaragüense ${ }^{34}$. Por ejemplo, el sujeto comete el hecho delictivo sobre una víctima que resulta ser su ascendiente, circunstancia que el autor desconocía; o el sujeto comete el delito cuando la víctima se encuentra indefensa, pero sin ser consciente aquél de esta circunstancia, o el autor comete el delito desconociendo que otro sujeto ha ofrecido una recompensa por la ejecución de ese mismo hecho.

\section{La regulación del art. 25.2 CP nicaragüense, excluyendo la apreciación} de la circunstancia agravante o del tipo cualificado, es una consecuencia de la vigencia del principio de responsabilidad subjetiva, y se ajusta además a la tesis doctrinal que considera que el fundamento de todas las circunstancias agravantes y tipos agravados estriba en el incremento del injusto del hecho (mayor desvalor de acción y/o de resultado) y no en el incremento o aumento de la culpabilidad ${ }^{35}$.

34 Esta misma diferenciación entre los elementos cualificadores típicos y las circunstancias agravantes genéricas se plantea en el CP español. Tal distinción ha sido objeto de críticas en la doctrina española, pues como ha apuntado MAQUEDA ABREU, De nuevo acerca del error sobre las circunstancias, en: LH Cerezo, 2002, 851, la diferencia entre unos y otros elementos es meramente formal, obedeciendo a una técnica legislativa diversa que para esta autora es más correcta y deseable cuando tales circunstancias se refieren a tipos concretos en los que adquieren su verdadera significación, pero resulta más incorrecta y rechazable en los casos en que se abandonan al supuesto de su eventual concurrencia en hechos distintos (refiriéndose a las agravantes genéricas). En todo caso advierte MAQUEDA ABREU que a efectos del desconocimiento los efectos en uno y otro caso son los mismos, y la única justificación para su regulación separada estriba en lo arraigado de la diferenciación tanto en la doctrina como en la jurisprudencia. En otro orden de cosas, RAMOS TAPIA, en: ZUGALDÍA ESPINAR (dir.)/PÉREZ ALONSO (coord.), PG, 2a, 2004, 519 s., advierte que, en general, no será habitual el error sobre las circunstancias agravantes genéricas, porque la mayoría de ellas conllevan elementos de carácter subjetivo o son de una naturaleza tal que difícilmente pueden concurrir sin que el sujeto lo sepa (y pone como ejemplos, las agravantes de alevosía, uso de disfraz, motivos racistas...), añadiendo que la posibilidad de plantear un error sobre las agravantes genéricas sí será más factible en casos de codelincuencia, cuando el partícipe desconozca la concurrencia de dicha circunstancia agravante genérica en la acción del autor.

35 Admiten esta interpretación en torno al fundamento de las circunstancias agravantes genéricas, entre otros, LUZÓN PEÑA, PG, I, 1996, 332 ss., 395; MAQUEDA ABREU, en: LH Cerezo, 2002, 855 n. 34; MARÍN DE ESPINOSA CEBALLOS, en: ZUGALDÍA ESPINAR (dir.)/PÉREZ ALONSO (coord.), PG, $2^{\mathrm{a}}$, 2004, 877 s.; MUÑOZ CONDE/GARCÍA ARÁN, PG, 7 $, 2007,476$, en la medida en que la circunstancia agravante previamente ha de afectar a la gravedad del hecho, con independencia de que, además, también pueda tener cierto componente que afecta a la mayor reprochabilidad del autor por el modo como ha cometido el hecho; MIR PUIG, PG, 8a , 2008, 622 s. Otra opinión es la que mantiene, entre otros, CEREZO MIR, PG, III/2, 2004, 159 ss.; DÍEZ RIPOLLÉS, PG, 2007, 474 ss., quienes admiten que existen circunstancias agravantes genéricas que aumentan la 
Revista de Perecho

\section{Además de la diferenciación entre el error sobre las circunstancias que fundamentan la infracción penal/el error sobre las circunstancias que cualifican la infracción penal o sobre una circunstancia agravante, en el $\mathrm{CP}$ nicaragüense se distingue entre el error vencible y el error invencible, con un distinto efecto en uno u otro caso: así, en el primero se diferencia entre el error vencible, que excluye el dolo pero deja subsistente la responsabilidad penal por el delito imprudente, en su caso, y el error invencible, que excluye tanto el dolo como la imprudencia ${ }^{36}$, mientras}

reprochabilidad personal por el hecho cometido (es decir, afectan, incrementándolo, la culpabilidad del sujeto). La regulación del error sobre las circunstancias agravantes del art. $25 \mathrm{CP}$ nicaragüense ha de ponerse en relación con lo dispuesto en el art. $77 \mathrm{CP}$ nicaragüense, precepto en el que se regula la comunicabilidad de las circunstancias agravantes y atenuantes en el ámbito de la codelincuencia, distinguiendo entre las circunstancias agravantes y atenuantes que consistan en la disposición moral del delincuente, en sus relaciones particulares con el ofendido o en otra causa personal, y las circunstancias agravantes y atenuantes que consistan en la ejecución material del hecho o en los medios empleados para realizarla: mientras que las primeras parecen exigir simplemente su concurrencia (y son incomunicables), las segundas exigen conocimiento de su existencia para su apreciación (y sí son comunicables). Ahora bien, una correcta comprensión de este art. $77 \mathrm{CP}$ nicaragüense en concordancia con lo dispuesto en el art. $25 \mathrm{CP}$ nicaragüense y con la vigencia del principio de responsabilidad subjetiva nos ha de llevar a entender que también para la apreciación de las circunstancias agravantes (y, en general, de las atenuantes) personales es necesario que el sujeto tenga conocimiento de su concurrencia. Así lo reconoce, entre otros, MIR PUIG, Op. cit., 271 s., quien refiriéndose al mismo precepto del CP español (art. 65) afirma que una correcta interpretación del mismo supone entender que para apreciar las circunstancias personales ha de exigirse el conocimiento de tales circunstancias.

36 Para más detalles sobre los efectos del error sobre los elementos constitutivos del tipo, vid., por todos, LUZÓN PEÑA, en: EJB, II, 1995, 2838 ss.; PG, I, 1996, 440 ss.; en: EPB, 2002, 655 ss. Admitido sin discusión que el error invencible de tipo excluye la responsabilidad penal, en la doctrina española la cuestión que se discute es si tal error invencible produce efectos más amplios, en concreto si excluye o no la responsabilidad civil. Al respecto el CP español en los preceptos que regulan la responsabilidad civil derivada del delito no menciona al art. 14 entre las eximentes que excluyen dicha responsabilidad, al contrario, se cita expresamente a este precepto para el establecimiento de esta clase de responsabilidad (art. 118.2 CP español). Sobre esta cuestión, LUZÓN PEÑA, PG, I, 1996, 446 n. 2; en: CDJ 2006-VII, 367 s., propone una interpretación que permita concluir que en el error invencible de tipo se excluye tanto la responsabilidad penal como la civil: interpretando el término "hecho" empleado en el art. 118.2 CP español como sinónimo de infracción, esto es, como conducta antijurídica; de este modo, quien sufre un error objetivamente invencible no comete un hecho antijurídico, por lo que no es autor de un hecho del que se pueda derivar responsabilidad civil. Sigue a este autor, DÍAZ Y GARCÍA CONLLEDO, en: LH Torío, 1999, 350 n. 37; Error elementos normativos del tipo, 2008, 154. De otra opinión, defendiendo que en el error objetivamente invencible de tipo se excluye la responsabilidad penal, pero no se excluye la responsabilidad civil (porque, además, así se establece en el art. 118.2 CP español), entre otros, SUÁREZ GONZÁLEZ, en: RODRÍGUEZ MOURULLO (dir.)/JORGE BARREIRO (coord.), Comentarios CP, 1997, 346, 348; COBO DEL ROSAL/VIVES ANTÓN, PG, 5a , 1999, 678; PASTOR ÁLVAREZ, en: COBO DEL ROSAL (dir.), Comentarios CP, IV, 2000, 505 ss., 523 ss.; BERDUGO GÓMEZ DE LA TORRE/ARROYO ZAPATERO/FERRÉ OLIVÉ/ GARCÍA RIVAS/SERRANO PIEDECASAS/TERRADILLOS BASOCO, PG, 2004, 533; MUÑOZ CONDE/ GARCÍA ARÁN, PG, 7ª 2007, 600 s.; QUINTERO OLIVARES, PG, 2a , 2007, 703. En el CP nicaragüense la cuestión puede estar resuelta legislativamente, si atendemos a las siguientes consideraciones. Por un lado, es preciso interpretar el art. 25.1 CP nicaragüense en consonancia con el principio de responsabilidad subjetiva (art. 9 CP nicaragüense) y con la eximente de caso fortuito (art. 34.9 CP nicaragüense), según la cual queda exento de responsabilidad penal cuando con ocasión de realizar una conducta lícita o ilícita se cause un mal por mero accidente, sin dolo ni imprudencia. De este modo, a través de la eximente de caso fortuito del art. 34.9 CP nicaragüense se puede incluir el error invencible de tipo en el catálogo de las eximentes. A continuación se comprueba la regulación de la responsabilidad civil derivada del delito en este texto legal, en concreto el art. 123 CP nicaragüense, y en él se comprueba que entre las eximentes que excluyen tanto la responsabilidad penal como la civil se incluye expresamente al caso fortuito (el art. $123 \mathrm{CP}$ nicaragüense menciona las eximentes que dan lugar sólo a la exclusión de la responsabilidad penal, pero dejan subsistente la responsabilidad civil, citando las eximentes de los numerales 1, 2, 3, 5 y 6 del art. 34, por lo que, en una interpretación a sensu contrario, el resto de las eximentes del art. 34 eximirán de responsabilidad penal y civil). Aunando ambas consideraciones se puede concluir que, en el Derecho nicaragüense el error (objetivamente) invencible de tipo excluye tanto la responsabilidad penal como la responsabilidad civil derivada del delito. 
que en el segundo simplemente se advierte que el error sobre tal circunstancia cualificadora o agravante, sea vencible o invencible, excluye su apreciación, quedando subsistente, por tanto, la responsabilidad penal por el delito básico cometido (ya que el sujeto sí tiene conocimiento de los elementos fundamentadores de esta infracción delictiva).

Esto significa que, como ya se ha indicado con anterioridad, en el error sobre las circunstancias que cualifican la infracción penal o sobre las circunstancias agravantes genéricas no se establece la diferenciación en cuanto a sus efectos entre el error vencible e invencible. Y la misma decisión legislativa se ha adoptado en el CP español, lo que no ha escapado a las críticas de un sector de la doctrina, que ha censurado esta equiparación punitiva entre el error vencible e invencible sobre tales elementos, sobre todo atendiendo a que en ocasiones el legislador español ha dejado abierta la posibilidad de castigar determinados tipos agravados cometidos imprudentemente ${ }^{37}$. Esto ha motivado que algunos autores hayan propuesto, pese a todo, un tratamiento diferenciado para el error vencible y el error invencible sobre las circunstancias cualificadoras de la infracción penal: bien proponiendo la apreciación de un concurso ideal entre el delito básico dolosamente cometido y el tipo cualificado imprudente ${ }^{38}$, bien recurriendo a la valoración de tal error vencible sobre los elementos de agravación en el marco de la determinación judicial de

37 Vid., en este sentido, ZUGALDÍA ESPINAR, en: COBO DEL ROSAL (dir.), Comentarios CP, I, 1999, 685, quien cita como ejemplo los daños imprudentes cometidos en bienes de valor histórico, artístico o cultural tipificados en el art. 324 CP español.

38 Esta es la solución que ha defendido ZUGALDÍA ESPINAR, en: COBO DEL ROSAL (dir.), Comentarios CP, I, 1999, 685, si bien a continuación advierte que el legislador, en el art. 14.2 CP español, "con un objetivismo difícil de comprender, ha intentado imponer por ley lo que no se puede imponer a través de un razonamiento y ha pretendido obligar a sancionar sólo por el tipo básico", lo que parece significar que definitivamente este autor descarta la solución del concurso ideal; RAMOS TAPIA, en: ZUGALDÍA ESPINAR (dir.)/PÉREZ ALONSO (coord.), PG, $2^{\text {a }}, 2004,519$, defiende en un plano teórico la solución del concurso ideal entre el tipo básico doloso y el tipo cualificado imprudente (evidentemente, cuando este sí se ha tipificado) para el caso de que se planteara un error vencible sobre el elemento que cualifica el hecho, pero a continuación reconoce que la regulación del art. 14.2 CP español impide la apreciación de esta solución concursal, pues la regulación sobre el error es clara: sea el error vencible, sea el error invencible, en ambos casos queda descartada la apreciación del tipo cualificado y en su lugar habrá que apreciar el tipo básico (porque respecto de los elementos constitutivos del tipo básico el sujeto sí ha actuado con dolo). Frente a la solución de la apreciación del concurso ideal entre el tipo básico doloso y el tipo cualificado imprudente, MAQUEDA ABREU, en: LH Cerezo, 2002, 853 s., advierte que puede resultar dudoso que la realización de un elemento de agravación por error vencible en el contexto de una conducta dolosa determine el carácter imprudente del conjunto de la infracción, en este caso del delito cualificado, y ello con independencia de la posible vulneración del principio ne bis in idem, porque en el error sobre la circunstancia cualificante lo único que se añade al hecho básico es la cualificación misma, por lo que "puede ser inoportuno proceder como si el resto de los momentos desvalorados se hubiera duplicado en el hecho". Con independencia de esta discusión sobre el tratamiento del error vencible sobre los elementos cualificantes, y de si es posible o no la apreciación del concurso ideal entre el tipo básico doloso y el tipo cualificado imprudente, es preciso recordar que a esta caracterización como posible concurso ideal entre tipo básico doloso y tipo cualificado imprudente, en su caso, correspondería también el tratamiento del error (directo) in persona o in obiecto relevante, cuando el sujeto desconoce la cualidad de la persona o del objeto que da lugar a una protección específica de tal persona u objeto a través del tipo cualificado o autónomo. 
la pena, atendiendo al desvalor del hecho adicional por la vencibilidad de dicho error ${ }^{39}$.

El mismo problema puede aparecer en el $\mathrm{CP}$ nicaragüense, si bien en una dimensión muy reducida. El ejemplo paradigmático puede plantearse en el ámbito de los delitos de lesiones, donde se distinguen entre tipos básicos y tipos agravados atendiendo a la gravedad de las lesiones cometidas (arts. 151 a $154 \mathrm{CP}$ nicaragüense), y, a su vez, se ha previsto tales tipos básicos y agravados en sus modalidades dolosa e imprudente (arts. 151 a 153 y 154 CP nicaragüense para las modalidades dolosa e imprudente respectivamente). En este caso habrá que decidir con carácter previo cómo se ha de definir el dolo respecto de los delitos de lesiones, si es suficiente con que el conocimiento y voluntad del sujeto se dirija a menoscabar la integridad física o salud o, por el contrario, es necesario además que el dolo abarque el concreto resultado producido ${ }^{40}$; sólo en este segundo caso podrán plantearse excesos imputables a la imprudencia del sujeto. Más claramente se podrá plantear la posibilidad de que el sujeto realice, con la misma acción, tanto el tipo básico doloso como el tipo cualificado imprudente en el caso de los delitos contra la seguridad común y, en concreto, en relación con los delitos de incendio, dolosos e imprudentes (arts. 319 y $323 \mathrm{CP}$ nicaragüense): porque en la tipificación del delito de incendio doloso (art. $319 \mathrm{CP}$ nicaragüense) se han distinguido hasta tres modalidades, el incendio de un bien mueble, el incendio de un bien inmueble y, genéricamente hablando, el incendio de determinados bienes inmuebles en el momento en que estos se encuentran concurridos; entre estas dos últimas modalidades típicas se puede establecer la relación entre el tipo básico/tipo cualificado o agravado, lo que supone la factibilidad de que se pueda plantear un posible error vencible sobre los elementos del tipo cualificado o agravado, error vencible que, teóricamente al menos, daría lugar a la posibilidad de formular la posible apreciación del delito de desastre imprudente tipificado en el art. $323 \mathrm{CP}$ nicaragüense. Por ejemplo, el

39 Esta es la solución que propone MAQUEDA ABREU, en: LH Cerezo, 2002, 854.

40 Sobre los mismos problemas en torno a la definición del dolo en los delitos de lesiones en el CP español, vid., por todos, DÍEZ RIPOLLÉS, Los delitos de lesiones, Tirant lo Blanch, 1997, 62 ss.; DÍAZ Y GARCÍA CONLLEDO/ PAREDES CASTAÑÓN, en DÍAZ Y GARCÍA CONLLEDO/PAREDES CASTAÑÓN (Coords.), Relevancia de la actuación de la víctima para la responsabilidad penal del autor. (A propósito de la STS de 17 de septiembre de 1999), Universidad de León, León, 2004, 53 ss.; MUÑOZ CONDE, DPPE, 16 a , Tirant lo Blanch, Valencia, 2007, 121; CARBONELL MATEU/GONZÁLEZ CUSSAC, en: VIVES ANTÓN/ORTS BERENGUER/CARBONELL MATEU/GONZÁLEZ CUSSAC/MARTÍNEZ-BUJÁN PÉREZ, DPPE, 2ª Tirant lo Blanch, Valencia, 2008, 124; QUERALT JIMÉNEZ, DP español. PE, 5a , Atelier, Barcelona, 2008, 93, 97 s. 
sujeto dolosamente prende fuego a una vivienda, pero en ese momento, por error vencible, desconoce que la vivienda está concurrida. A la vista de este ejemplo, también en el CP nicaragüense se podría plantear el problema concursal entre el tipo básico doloso y el tipo cualificado imprudente, si bien la regulación positiva del error sobre los elementos que califican el hecho (art. 25.2 CP nicaragüense) nos ha de llevar a descartar la solución del concurso ideal entre estas dos infracciones, ya que el legislador ha sido claro al decidir que, para el caso del error sobre tales elementos calificadores, sea el error vencible, sea el error invencible, en todo caso queda descartada la apreciación de la cualificación, lo que supone la exclusión del tipo cualificado, tanto en su modalidad dolosa como en la imprudente. En cuanto a la otra posibilidad planteada por la doctrina española, valorar el adicional desvalor del hecho derivado del error vencible sobre la circunstancia cualificadora en la determinación de la pena del tipo básico dolosamente cometido, tal recurso sí es factible atendiendo a lo dispuesto en el art. 78.a CP nicaragüense, que dispone que para la individualización judicial de la pena se habrá de valorar las circunstancias personales del sujeto y la mayor o menor gravedad del hecho.

Como se ha señalado anteriormente, se diferencia entre el error vencible e invencible de tipo, cada uno con diferentes efectos. Pero en el art. $25 \mathrm{CP}$ nicaragüense no se ofrece ningún criterio para averiguar cuándo el error es vencible y cuando el error es invencible. Ésta es una diferencia cualitativa con el CP español, donde el legislador sí ha creído oportuno introducir criterios que sirvan para la apreciación de la vencibilidad o invencibilidad del error: se ha de tener en cuenta las circunstancias del hecho y las personales del autor ${ }^{41}$. Aquella decisión ha de ser valorada positivamente, al no prejuzgar de antemano cuál es la posición sistemática del dolo y de la imprudencia, dejando abierta a la discusión doctrinal si son formas o elementos de la culpabilidad o del tipo (global) de injusto, y dejando también sin resolver la forma como ha de entenderse el elemento básico del delito imprudente, la infracción

41 Tal regulación en el CP español ha sido criticada por LUZÓN PEÑA, en: EJB, II, 1995, 2839 s.; PG, I, 1996, 444; en: EPB, 2002, 658, porque los criterios que sirven para valorar el error vencible dando lugar a la responsabilidad por el delito imprudente son una mezcla de elementos atinentes al injusto y a la culpabilidad. Propone este autor realizar una interpretación del art. 14.1. CP español correctora de esta equivocidad: la referencia a las circunstancias del hecho y las personales del autor debe interpretarse en el sentido de "cómo operaría el hombre ideal colocado en las circuntancias personales del autor; pues si el error es objetivamente vencible, hay imprudencia -cuestión de injusto- aunque sea un error subjetivamente invencible, lo que sólo excluye la culpabilidad individual por esa infracción imprudente". 
Revista de Perecho

del deber de cuidado o diligencia (si es la infracción del deber objetivo de cuidado o la infracción del deber subjetivo de cuidado) ${ }^{42}$.

\section{El error de prohibición: art. $26 \mathrm{CP}$ nicaragüense}

\section{Como ya se ha mencionado anteriormente, el CP nicaragüense incluye una regulación específica del error de prohibición, distinguiéndolo del error de tipo en cuanto a sus efectos ${ }^{43}$, y se utiliza expresamente esta}

42 Esta cuestión es objeto de controversia en la doctrina española. Así, y como mera ejemplificación de esta discrepancia en la interpretación del deber de cuidado en el delito imprudente, para ZUGALDÍA ESPINAR, en: COBO DEL ROSAL (dir.), Comentarios CP, I, 1999, 681 y n. 4, la regulación del CP español es correcta, porque la imprudencia del autor en el error vencible de tipo se debe a la infracción de un deber objetivo y subjetivo de cuidado. Advierte este autor que la infracción del deber subjetivo de cuidado no pertenece a la culpabilidad, sino al tipo de injusto del delito imprudente; la infracción del deber de cuidado debe valorarse teniendo en cuenta los conocimientos y capacidades individuales del autor. Siguen este planteamiento, entre otros, BERDUGO GÓMEZ DE LA TORRE/ARROYO ZAPATERO/FERRÉ OLIVÉ/GARCÍA RIVAS/SERRANO PIEDECASAS/TERRADILLOS BASOCO, PG, 2004, 268 s.; RAMOS TAPIA, en: ZUGALDÍA ESPINAR (dir.)/PÉREZ ALONSO (coord.), PG, 2ª 2004, 534 ss. De otra opinión LUZÓN PEÑA, PG, I, 1996, 498 ss., quien exige infracción del deber objetivo de cuidado como núcleo esencial de la conducta imprudente: es el deber objetivo-general de cuidado que se impone a todos los ciudadanos en esa situación o en este tipo de actividad, y que en esa situación o posición es capaz de cumplir el hombre diligente y cuidadoso. Para el caso de que el sujeto concreto tenga un conocimiento especial y superior a la media, tales conocimientos también habrán de ser tenidos en cuenta para la valoración de la infracción del deber objetivo de cuidado (no se tendrán en cuenta para establecer el núcleo de la conducta imprudente, la infracción del deber de cuidado, las capacidades superiores al ciudadano o profesional medio, y tampoco se tendrán en cuenta los conocimientos y capacidades inferiores al ciudadano o profesional medio, si bien estos conocimientos y capacidades inferiores al hombre medio ideal serán valorados en la culpabilidad). Una postura muy próxima a la que defiende este último autor es la que mantiene MIR PUIG, PG, 8 $8^{a}, 2008,289$ ss. También defienden que el contenido del injusto del delito imprudente está formado por la infracción del deber objetivo de cuidado, entre otros, CEREZO MIR, PG, II, 6ª , 1998, 160 ss.; DÍEZ RIPOLLÉS, PG, 2007, 195 ss.; MUÑOZ CONDE/GARCÍA ARÁN, PG, 7ª , 2007, 284 ss.

43 Si bien esto no significa, como se ha expuesto anteriormente, el reconocimiento de la teoría de la culpabilidad en la regulación del error de prohibición, pues en la exégesis de este art. 26 CP nicaragüense puede perfectamente defenderse la tesis de autores como MIR PUIG, PG, $8^{\text {a }}$, 2008, 532 ss., 556 ss., quien sigue defendiendo la teoría del dolo en el tratamiento del error de prohibición, a la vista de la regulación positiva de este error en el CP español, una regulación que es idéntica a la del CP nicaragüense. Parte este autor de la consideración de que no se puede afirmar la prohibición del hecho al autor cuando éste no puede conocer su antijuridicidad penal: la posibilidad de conocimiento de la norma de determinación, entendida como imperativo concreto, es una condición de aplicación tácita de la misma. Así, afirma este autor que "el DP se justifica por la función de protección de bienes jurídicos a través de la motivación de la norma (...), sólo puede prohibir aquellos comportamientos que puedan evitarse mediante la motivación. Ahora bien, para que el sujeto pueda ser motivado por una norma penal que protege un bien jurídicopenal determinado, es preciso que dicho sujeto pueda saber que se encuentra frente a un tal bien protegido por el Derecho. Si el sujeto no puede saber que su acción va a lesionar un bien amparado por el Derecho ¿cómo podrá sentirse motivado a evitar dicha acción por la norma penal, si no puede ser motivado por ella? Y si la norma no puede motivarlo no tiene sentido que lo intente prohibiéndole el hecho". El error de prohibición excluye el tercer y último nivel necesario para que el dolo sea dolus malus: la conciencia de la antijuridicidad (el primer nivel está formado por el conocimiento del tipo, necesario para el dolo típico, y el segundo nivel por el conocimiento de los presupuestos típicos de una causa de justificación, que exige el dolo del tipo negativo); si el error es vencible deja paso a la imprudencia de Derecho por la falta de cuidado que el sujeto demuestra al no haber advertido la antijuridicidad, y si es invencible determina la impunidad por falta de dolo e imprudencia (pp. 553 s.). Y también puede defenderse la teoría limitada del dolo, diferenciada de la tesis de MIR PUIG en un dato fundamental, en la consideración del dolo y la imprudencia como elementos de la culpabilidad. Una lectura del art. 26 CP nicaragüense desde el planteamiento de la tradicional teoría limitada del dolo significaría lo siguiente: el error de prohibición invencible excluiría la responsabilidad penal, por falta de dolo e imprudencia, mientras que el error de prohibición vencible sólo excluiría el dolo, pero dejaría subsistente la responsabilidad penal por la imprudencia iuris, que se castigaría en todo caso, y el art. 26.2 CP nicaragüense no tendría otro sentido que actuar a modo de cláusula general de determinación de la pena de la imprudencia iuris. Esta concepción de la teoría limitada del dolo, aplicada en la interpretación del CP español, es defendida en la doctrina española, entre 
denominación en la rúbrica empleada en la denominación del precepto que lo regula (en un artículo independiente al error de tipo) así como en la referencia a los efectos del error vencible "sobre la prohibición del hecho" (art. 26.2 CP nicaragüense). La similitud con el CP español también se hace notar aquí al reconocer la atenuación obligatoria de la pena para el caso de que el error de prohibición sea vencible, siendo esta una diferencia fundamental con otros $\mathrm{CP}$ como el alemán y $\mathrm{CP}$ iberoamericanos como el brasileño, el colombiano o el costarricense.

El error de prohibición se puede definir como el supuesto en el que el sujeto, conociendo todos los elementos fundamentadores o presupuestos de la prohibición de la conducta, desconoce dicha valoración general negativa de su conducta, desconoce la prohibición o antijuridicidad de su comportamiento ${ }^{44}$.

Dentro del error de prohibición se distingue entre el error directo y el error indirecto de prohibición: el primero es el que recae sobre los mandatos o prohibiciones (abstractas) de la ley, pudiéndose manifestar de diversas formas: porque el sujeto desconoce la existencia de la norma jurídica que prohíbe u ordena la conducta que se dispone a realizar; o porque desconoce el alcance de la prohibición, lo que le lleva a realiza una interpretación equivocada de la misma; o porque se equivoca sobre la validez de la norma de prohibición, bien porque cree que ha sido derogada por otra norma posterior, bien porque cree que tal norma contradice lo dispuesto en normas de rango superior (en especial, porque cree equivocadamente que infringe la Constitución) ${ }^{45}$. Como ejemplos del error de prohibición directo se citan por la doctrina los siguientes: el sujeto no sabe que está prohibido apropiarse de cosas perdidas o de tesoros descubiertos (art. 239.a y c CP nicaragüense), o por una interpretación incorrecta de la norma cree que a su conducta no se le aplica el tipo de estafa (arts. 229 y ss. CP nicaragüense), o para el ejercicio de determinada profesión no se precisa título académico alguno (art. 298 CP nicaragüense), o cree que el acceso carnal con menor de 14 años es lícito si el menor presta su consentimiento (art. 168 CP nicaragüense), o alguien graba en cinta magnetofónica sin que

otros, por OLMEDO CARDENETE, en: COBO DEL ROSAL (dir.), Comentarios CP, II, 1999, 568 ss., y n. 188 p. 568.

44 Como ya se ha indicado con anterioridad, es la definición propuesta por LUZÓN PEÑA, en: EJB, II, 1995, 2843; PG, I, 1996, 462; en: EPB, 2002, 661.

45 Para más detalles sobre las formas de manifestarse el error directo de prohibición, por todos, ROXIN, AT, I, $4^{\mathrm{a}}$, 2006, 937 ss. (= PG, I, 1997, 870 ss.); DÍEZ RIPOLLÉS, PG, 2007, 429; OLAIZOLA NOGALES, Error de prohibición, 2007, 89 ss. 
lo sepa su interlocutor la conversación telefónica que está manteniendo y luego hace pública esa conversación, sin sospechar que tal conducta pueda estar prohibida (art. 192 CP nicaragüense), o considera que una disposición legal no está vigente porque ha sido derogada o porque es contraria a la Constitución ${ }^{46}$.

El error de prohibición indirecto es el que recae sobre causas de justificación: el sujeto sabe lo que hace, y sabe que tal comportamiento está prohibido con carácter general, pero cree que excepcionalmente está autorizado a actuar porque concurre una causa de justificación. Ya no hay acuerdo doctrinal en la extensión de los supuestos de error de prohibición indirecto, pues se distinguen tres clases de errores sobre causas de justificación: el error sobre la existencia de una causa de justificación, el error sobre los límites de una causa de justificación y el error sobre los presupuestos objetivos de una causa de justificación. Sólo los dos primeros se admiten sin discusión como modalidades del error de prohibición (y algunos autores concluyen que sólo hay una modalidad, el error sobre la existencia de una causa de justificación, pues carece de sentido plantear de forma autónoma el error sobre los límites de las causas de justificación) ${ }^{47}$, siendo discutido el tratamiento de la tercera clase de error ${ }^{48}$. Como ejemplos de errores sobre la existencia o límites de las causas de justificación se suelen citar los siguientes: el médico opera

46 Los ejemplos han sido tomados de ZUGALDÍA ESPINAR, en: COBO DEL ROSAL (dir.), Comentarios CP, I, 1999, 686 s.; y de ROXIN, AT, I, 4ª , 2006, 927 (= PG, I, 1997, 861), adaptándolos a la regulación del PCP nicaragüense.

47 Para más detalles sobre la tesis que mantiene que, en relación con el error sobre causas de justificación, las modalidades de error sobre los límites y sobre la existencia de la causa de justificación no son diferenciables, englobando ambos supuestos dentro de la genérica de error sobre los límites de la causa de justificación, TRAPERO BARREALES, El error en las causas de justificación, Tirant lo Blanch, 2004, 489 ss. Admiten la triple caracterización del error de prohibición indirecto (o la distinción entre el error sobre los límites y el error sobre la existencia de una causa de justificación para aquellos que admiten que la otra modalidad del error sobre causas de justificación, el error sobre los presupuestos objetivos de una causa de justificación, no es un error de prohibición), entre otros, LUZÓN PEÑA, en: EJB, II, 1995, 2851; PG, I, 1996, 482 s.; en: EPB, 2002, 670; RODRÍGUEZ MOURULLO, en: RODRÍGUEZ MOURULLO (dir.)/JORGE BARREIRO (coord.), Comentarios CP, 1997, 68 s.; COBO DEL ROSAL/VIVES ANTÓN, PG, 5a , 1999, 672 s.; BERDUGO GÓMEZ DE LA TORRE/ARROYO ZAPATERO/FERRÉ OLIVÉ/GARCÍA RIVAS/SERRANO PIEDECASAS/TERRADILLOS BASOCO, PG, 2004, 346; ZUGALDÍA ESPINAR, en: ZUGALDÍA ESPINAR (dir.)/PÉREZ ALONSO (coord.), PG, 2ª, 2004, 608 s.; DÍEZ RIPOLLÉS, PG, 2007, 429; MUÑOZ CONDE/GARCÍAARÁN, PG, 7ª , 2007, 382 s.; OLAIZOLA NOGALES, Error de prohibición, 2007, 96 ss. La diferenciación entre el error sobre los límites y el error sobre la existencia de una causa de justificación puede tener relevancia si se quiere establecer un efecto doblemente atenuador en la primera de las modalidades. La doble atenuación de la responsabilidad penal se produciría de la siguiente manera: en primer lugar, se puede defender que en el error sobre los límites de la causa de justificación los requisitos esenciales de la causa de justificación concurren efectivamente, y el sujeto tiene conocimiento de ello, lo que daría lugar a apreciar la eximente incompleta (arts. 35.1 y $80 \mathrm{CP}$ nicaragüense); en segundo lugar, sólo respecto de los requisitos o elementos inesenciales el sujeto incurriría en el error de prohibición, por lo que, en caso de error vencible, se podría apreciar, además, la disminución de la pena establecida en el art. $26.2 \mathrm{CP}$ nicaragüense.

48 De esta tercera clase de error sobre las causas de justificación nos ocuparemos brevemente en el siguiente apartado sobre los supuestos problemáticos y/o sin regulación positiva. 
contra la voluntad del paciente, ejercitando un derecho de la profesión médica que, en realidad, no existe; o cree que la ley autoriza los castigos corporales a los niños; o se cree autorizado a matar en legítima defensa para evitar la sustracción de un reloj; o el sujeto ha sido injuriado y cree que le asiste el derecho de retorsión o devolución de unas injurias equivalentes; o cree que aún le asiste una legítima defensa frente a una agresión sufrida, disparando cuando el agresor huye; o el subordinado cumple una orden manifiestamente antijurídica en la creencia de que su deber de obediencia es ilimitado; o el marido separado entra en la vivienda de su mujer, para recoger enseres personales, reconociendo que es vivienda ajena, porque se cree autorizado para ello ${ }^{49}$.

\section{Varias son las cuestiones que siguen estando en el centro del debate doctrinal en el análisis del error de prohibición:}

La primera cuestión que suscita el interés de la doctrina es la relativa a la conveniencia u oportunidad en el diferente tratamiento del error de tipo y el error de prohibición, así como si resulta acertado o no el efecto atenuador obligatorio de la responsabilidad penal en el error vencible de prohibición.

A este respecto la doctrina más autorizada en la actualidad defiende la plena justificación del distinto tratamiento entre ambas clases de errores, a pesar de que algunos supuestos pueden plantear dificultades en la delimitación entre el error de tipo y el error de prohibición ${ }^{50}$,

49 Los ejemplos han sido planteados por LUZÓN PEÑA, PG, I, 1996, 482 s.; y ZUGALDÍA ESPINAR, en: COBO DEL ROSAL (dir.), Comentarios CP, I, 1999, 687 s. En relación con el ejemplo relativo a los castigos corporales a niños, y para el caso de que el castigo corporal lo ejecute alguno de los padres del menor, ha de tenerse en cuenta que en el DP nicaragüense sí se reconoce como causa de justificación el derecho de corrección en relación con los hijos propios o los hijos del cónyuge o conviviente, tal como se deduce del art. $155 \mathrm{CP}$ nicaragüense. En este caso, para valorar el error sobre los límites o sobre la existencia del derecho de corrección, habrá que delimitar, en primer lugar, quién puede actuar justificadamente en el ejercicio del derecho de corrección y, en segundo lugar, cuál es el límite de esta causa de justificación.

50 Así, por ejemplo, MIR PUIG, en: COBO DEL ROSAL (dir.), Comentarios CP, I, 1999, 663 ss., plantea los siguientes supuestos en los que resulta difícil diferenciar entre el error de tipo y el error de prohibición: el error sobre elementos normativos del tipo, el error sobre los elementos de la valoración global del hecho (y cita como ejemplo, el elemento relativo a la ilegalidad en el delito de nombramientos ilegales - art. 436 CP nicaragüense-), el error sobre los elementos de valoración global del hecho que condicionan la antijuridicidad y el propio significado social negativo específico (y cita el ejemplo de ROXIN, AT, I, 4ª 2006, 490 s. = PG, I, 1997, 464 s., en el delito de defraudación tributaria, el deber extrapenal de pagar impuestos o el carácter indebido del disfrute de beneficios fiscales -arts. 303 ss. CP nicaragüense-) y el error en las leyes penales en blanco (por ejemplo, los delitos contra el patrimonio cultural de la nación, arts. 299 ss. CP nicaragüense, o los delitos de construcciones prohibidas y contra el medio ambiente, arts. 363 ss. CP nicaragüense). De todas formas, pese a ser un claro defensor de la teoría modificada del dolo (el dolo concebido como elemento del tipo de injusto), MIR PUIG sigue siendo partidario del diferente tratamiento del error de tipo y el error de prohibición, proponiendo que el error vencible de prohibición se castigue de forma generalizada y sólo de forma excepcional el error vencible de tipo, y ello porque "la afirmación de que el conocimiento del completo significado del hecho requiere la conciencia 
porque ha de reconocerse prima facie que entre el error de tipo y el error de prohibición hay una diferencia fundamental: en el primer caso, el sujeto desconoce la situación objetiva en la que se dispone a actuar, y tal desconocimiento de la realidad objetiva hace que no perciba la dañosidad o lesividad de su conducta, por lo que tampoco tiene motivos objetivamente razonables para plantearse la posible antijuridicidad de su comportamiento. Pero en el error de prohibición el sujeto percibe perfectamente la situación objetiva, actúa con dolo respecto del tipo (global) de injusto, y tal conocimiento es lo que permite al ciudadano medio ideal reconocer la antijuridicidad del comportamiento que se está realizando (es lo que se denomina la función de llamada del dolo) ${ }^{51}$.

En cuanto a la conveniencia del efecto atenuatorio obligatorio del error vencible de prohibición, también ésta es una decisión acertada del legislador ${ }^{52}$, ya que ha de tenerse en cuenta que para el ciudadano medio también resulta difícil tener conocimiento actual de la prohibición del comportamiento en una época como la actual en la que prolifera la actividad legislativa, regulando mayores y más complejos sectores de la actividad, a veces recurriendo a leyes especiales, o utilizando elementos normativos jurídicos, actividades en las que resulta difícil percibir la lesividad o dañosidad de las conductas para un interés o bien jurídico que no está claramente definido ${ }^{53}$. Hasta tal punto resulta necesario

de su significado jurídico, es compatible con la apreciación político-criminal de que acaso convenga estimular el conocimiento del Derecho tratando con más rigor el error sobre el mismo que el error sobre el significado social del hecho. Pero esta fundamentación político-criminal del problema tal vez permitiría flexibilizar la diferencia de tratamiento indicada, de modo que hiciera posible excluir del trato de rigor del error de prohibición a casos en que el desconocimiento del Derecho no está motivado por el desconocimiento de la letra de la ley, sino por la ambigüedad de ésta o por su excesiva lejanía respecto a su interpretación jurisprudencial". En general, sobre los posibles argumentos esgrimidos por la doctrina para rechazar el distinto tratamiento del error de tipo y el error de prohibición, DÍAZ Y GARCÍA CONLLEDO, en: LH Torío, 1999, 341 s., los sintetiza en los siguientes: en primer lugar, no se justifica el diferente tratamiento entre las dos clases de error, planteando un privilegio injustificado para el error vencible de tipo; en segundo lugar, la distinción tajante entre el error de tipo y el de prohibición es cuestionable y a veces difícil de llevar a la práctica, como sucede con los elementos normativos del tipo, las leyes penales en blanco y los elementos de valoración global del hecho; y en tercer lugar, porque a efectos de imputación penal lo único relevante es que el sujeto desconozca la ilicitud de su hecho con independencia de si tal desconocimiento tiene su origen en la falta de conciencia de una circunstancia de hecho o en la ignorancia de que las normas desaprueban la conducta que realiza.

51 Para más detalles, por todos, LUZÓN PENAA, en: EJB, II, 1995, 2838 s., 2843; PG, I, 1996, 440 s., 462; en: EPB, 2002, 656, 661; DÍAZ Y GARCÍA CONLLEDO, en: LH Torío, 1999, 341 ss.; Algunas cuestiones del error en DP, en: LH Roxin (Lisboa), 2002, 73 ss., quien advierte que si bien es cierto que es difícil de distinguir entre el error de tipo y el de prohibición en los elementos normativo del tipo, ello también es compatible con los esfuerzos por parte de la doctrina para conseguir tal diferenciación; ROXIN, AT, I, 4a , 2006, 485 ss. (= PG, I, 1997, 459 ss.).

52 De otra opinión, BACIGALUPO ZAPATER, en: LL 1996-3, 1430; PG, $5^{\text {a }}$, 1998, 316, 323, quien, refiriéndose a la atenuación de la pena en el error vencible de prohibición en el CP español, ha afirmado que tal atenuación es exagerada, y añade además que se deben reducir los efectos de la obligatoriedad de la atenuación, proponiendo una formulación que permita la atenuación dentro del marco penal establecido para el delito concretamente cometido, como si fuera una atenuante ordinaria.

53 Para más detalles, por todos, DÍAZ Y GARCÍA CONLLEDO, en: LH Torío, 1999, 345 ss.; en: LH Roxin (Lisboa), 2002, 74 s., quien advierte que la existencia del DP accesorio y de elementos normativos de difícil interpretación, 
el tratamiento favorable del error de prohibición, admitiendo como mínimo el efecto atenuatorio obligatorio en esta clase de error, que en otros ordenamientos jurídicos como el alemán, en el que la atenuación de la pena en el error vencible de prohibición es meramente facultativa, la doctrina ha propuesto una mayor flexibilización del tratamiento del error en aquellos supuestos en los que resulta muy difícil diferenciar entre el error de tipo y el error de prohibición, y particularmente en el llamado DP accesorio o especial. Tal flexibilización en el tratamiento del error puede consistir o en una regulación específica, o, a falta de regulación específica, en una interpretación del error de prohibición en el DP especial siguiendo los criterios de la teoría del dolo ${ }^{54}$, o en una flexibilización en la aplicación de la teoría de la culpabilidad, flexibilización que puede realizarse desde dos perspectivas: la primera, atenuando de forma obligatoria, y con una rebaja sustancial de la pena, el error vencible de prohibición, y la segunda, admitiendo con mayor amplitud el error invencible de prohibición ${ }^{55}$.

inclusive para los expertos, hacen necesario que el tratamiento del error de prohibición se aproxime al error de tipo, concediendo mayor relevancia a esta clase de error y flexibilizando los criterios para la apreciación de su invencibilidad. Y añade que desde esta perspectiva resulta acertada la decisión del legislador español, y en consecuencia también la decisión del legislador nicaragüense, de rebajar obligatoriamente la pena en el error de prohibición vencible, y llegando a una atenuación de la pena muy cualificada (en el CP español se puede rebajar la pena hasta dos grados, mientras que en el CP nicaragüense se puede llegar hasta la cuarta parte del límite mínimo previsto para el delito de que se trate); CEREZO MIR, PG, III/2, 2004, 129; DÍEZ RIPOLLÉS, PG, $2007,437$. Sobre esta cuestión, ROXIN, AT, I, 4ª , 2006, 931 (= PG, I, 1997, 865), advierte que la teoría de la culpabilidad en el StGB alemán pierde poder de convicción en aquellos tipos penales en los que la dañosidad social de la conducta no es deducible sin más del conocimiento de las circunstancias fundamentadoras del injusto jurídicopenal. Y esto es lo que sucede en el DP accesorio y en el DP especial. Propone este autor que en estos casos se haga un uso generoso de la posibilidad de atenuación de la pena, cuando no de la apreciación también de forma amplia de la invencibilidad del error de prohibición. Es preciso advertir que en el StGB alemán la atenuación de la pena en el error vencible de prohibición es meramente facultativa, no obligatoria, de ahí que el autor alemán proponga una mayor flexibilidad para apreciar de forma más generosa la vencibilidad de dicho error, flexibilidad que se consigue fácilmente en los CP como el español o el nicaragüense en los que la atenuación de la pena en el error de prohibición vencible es obligatoria, y se puede alcanzar una rebaja de la pena que lleva en ocasiones a una pena mínima.

54 Vid., para más detalles, TIEDEMANN, en: LH Casabó, II, 1997, 897 ss., 905 ss. También en la doctrina española en los últimos años se ha analizado la conveniencia o no de proponer una regulación especial del error en el ámbito del denominado DP especial o no nuclear, particularmente, en el DP económico, y ello con independencia de que la regulación del error de prohibición (vencible) es claramente más beneficiosa en el DP español, porque, como ya hemos indicado, la rebaja de pena es obligatoria, pudiendo llegar a ser una rebaja sustanciosa (hasta dos grados) de dicha responsabilidad penal. Pero de todas formas tal regulación puede resultar insatisfactoria si lo que se pretende es un tratamiento más benévolo del error en el DP no nuclear, pues para lograr la impunidad en los casos de error en este ámbito habría que forzar la interpretación del error como error de tipo (en cuyo caso en la práctica totalidad de los casos se declararía la impunidad del sujeto, ya que en el ámbito de los delitos económicos sólo se ha tipificado la modalidad dolosa y muy excepcionalmente puede existir un delito imprudente), o la interpretación del error como error invencible de prohibición (para todos los demás supuestos que no se puedan resolver a través de las reglas del error de tipo). Para más detalles sobre las distintas propuestas doctrinales suscitadas en torno al tratamiento especial del error en el ámbito del DP económico (defendiendo la interpretación de cualquier error sobre elementos normativos del tipo, de profusa utilización en este sector del ordenamiento jurídico, como error de tipo, o recurriendo a una interpretación generosa de la invencibilidad del error de prohibición), ampliamente, MARTÍNEZ-BUJÁN PÉREZ, DP Económico. PG, 2a , 2007, 398 ss., 403 ss.

55 Vid., en este sentido, ROXIN, AT, I, 4a , 2006, 931 (= PG, I, 1997, 865), quien rechaza el recurso a la teoría del dolo para el DP especial o el DP accesorio en el tratamiento del error de prohibición, porque el recurso a dicha 
Con la explicación ofrecida hasta ahora se ha podido justificar la decisión del legislador nicaragüense de distinguir entre el error de tipo y el error de prohibición, proponiendo la atenuación obligatoria de la pena en el error vencible de prohibición. Pero esta decisión no está exenta de posibles críticas, porque puede llevar en la práctica a discutibles efectos atenuatorios de la responsabilidad penal en los casos denominados por la doctrina de errores de prohibición basados en ceguera jurídica u hostilidad hacia el Derecho (o errores burdos) ${ }^{56}$ : pese a que el sujeto revela una ignorancia crasa del Derecho incomprensible absolutamente, le faltaría la conciencia actual de la antijuridicidad de su conducta, por lo se beneficiaría de la atenuación obligatoria de la pena para el error vencible de prohibición.

Para evitar esta posible crítica en la doctrina española se ha propuesto alguna solución que supone la inaplicación de las reglas del error de prohibición en el tratamiento de los supuestos de ceguera jurídica, interpretación que podría ser trasladable a la exégesis del $\mathrm{CP}$ nicaragüense. En concreto, se ha indicado que en estos casos la capacidad de motivación del sujeto por la norma no está disminuida ni anulada, ya que la ignorancia de las normas en estos casos se debe a una actitud de bloqueo ante lo jurídico voluntaria, cuando no predispuesta ${ }^{57}$. Y para adaptar esta interpretación a la regulación del CP nicaragüense, que

teoría llevaría a la absolución generalizada en el error vencible de prohibición debido a que en estos sectores del DP no se suelen tipificar delitos imprudentes. Pero, a juicio de este autor, una absolución generalizada para el error de prohibición supondría en la práctica una paralización de los esfuerzos por conocer el Derecho y derogaría en la práctica las normas que nadie conoce. Por tal motivo propone ROXIN realizar una interpretación flexible de la teoría de la culpabilidad en este ámbito, flexibilización que consistiría en aplicar más generosamente la atenuación del error vencible de prohibición o la valoración de tal error de prohibición como invencible. En contra del recurso a la teoría del dolo en el tratamiento del error en el DP accesorio o especial también DÍAZ Y GARCÍA CONLLEDO, en: LH Torío, 1999, 364 s., advirtiendo que en muchos casos en el DP accesorio el sujeto va a tener un motivo para examinar la situación jurídica, al tratarse de un sector sometido a una regulación jurídica específica (siendo éste un criterio a tener en cuenta para valorar la vencibilidad del error de prohibición). Y en segundo lugar, tampoco resulta acertado aventurar que en el DP accesorio y/o especial serán muy frecuentes los errores invencibles de prohibición, pues ha de tenerse en cuenta que en estos ámbitos el sujeto suele estar asesorado por expertos en la materia. Y en todo caso, cuando existan las dificultades señaladas por la doctrina para lograr el conocimiento de la antijuridicidad bastará con una flexibilización de los criterios sobre la vencibilidad e invencibilidad del error de prohibición para lograr el efecto buscado: subsanar las diferencias del tratamiento del error de tipo y el error de prohibición; Error elementos normativos del tipo, 2008, 174 s. Defiende la misma tesis sobre la flexibilización de la teoría de la culpabilidad de ROXIN, pero teniendo en cuenta las matizaciones realizadas por DÍAZ Y GARCÍA CONLLEDO, OLAIZOLA NOGALES, Error de prohibición, 2007, 141 s.

56 Vid., para más detalles sobre esta cuestión, por todos, LUZÓN PEÑA, en: EJB, II, 1995, 2843 s.; PG, I, 1996,463 s.; en: EPB, 2002, 662.

57 Vid., para más detalles, LUZÓN PEÑA, en: EJB, II, 1995, 2843 s.; PG, I, 1996, 463 s.; en: EPB, $2002,662$. Admite esta argumentación, DÍAZ Y GARCÍA CONLLED, en: LH Torío, 1999, 352; en: LH Roxin (Lisboa), 2002, 77; Error elementos normativos del tipo, 2008, 164 n. 13. Descartan esta interpretación propuesta por los autores españoles, CEREZO MIR, PG, III/2, 2004, 126, quien añade que en la regulación del error de prohibición en el CP español (y la misma opinión cabe extenderla al CP nicaragüense) no cabe excluir los supuestos de ignorancia burda debida a ceguera jurídica u hostilidad al Derecho; DÍEZ RIPOLLÉS, PG, 2007, 437. 
exige conocimiento de la ilicitud del hecho, podría entenderse que el término "error" no abarca los supuestos de ignorancia, haciendo una interpretación de dicho término en el sentido usual del lenguaje en el que se diferencia claramente entre la ignorancia y el error ${ }^{58}$.

La segunda cuestión que merece ser mencionada en una valoración general de la regulación del error en el CP nicaragüense es la relativa al conocimiento necesario para excluir el error deprohibición, odichodeotra manera, el conocimiento necesario para afirmar la plena responsabilidad penal del sujeto. Sobre este particular ha de tenerse en cuenta que el $\mathrm{CP}$ nicaragüense hace referencia al error vencible o invencible sobre la ilicitud (o sobre la prohibición) del hecho constitutivo de la infracción, lo que parece significar que se requiere conocimiento actual por parte del sujeto de la ilicitud de la conducta que se dispone a realizar, no bastando con el conocimiento potencial de la antijuridicidad ${ }^{59}$, y parece referirse exclusivamente a los supuestos de error sobre la ilicitud del hecho, por lo que podría plantearse la duda de si se incluye o no en esta regulación del error de prohibición los supuestos de ignorancia sobre la antijuridicidad de la conducta ${ }^{60}$. Pero el CP nicaragüense no se pronuncia sobre cuál es el contenido u objeto del conocimiento necesario para afirmar la plena responsabilidad penal y para valorar su reverso, el error de prohibición.

Sobre esta cuestión se puede afirmar que en la actualidad la postura doctrinal mayoritaria exige el conocimiento de la antijuridicidad de la conducta, el conocimiento de la prohibición jurídica general del hecho, no bastando con la conciencia de que la conducta está desvalorada moral o socialmente ${ }^{61}$. Pero para un sector minoritario de la doctrina este

58 Es la interpretación que propone DÍAZ Y GARCÍA CONLLEDO, en: LH Torío, 1999, 352 ss.; en: LH Roxin (2002), $76 \mathrm{~s}$

59 Sobre esta cuestión, vid., ampliamente, DÍAZ Y GARCÍA CONLLEDO, en: LH Torío, 1999, 351; en: LH Roxin (Lisboa), 2002, 76, quien advierte que en la regulación penal española (y lo mismo puede afirmarse de la regulación en el CP nicaragüense) "la existencia de un error es decisiva, pues, aunque sea vencible, dará lugar a que no sea posible la culpabilidad plena (dada la atenuación obligatoria que impone el art. 14.3 CP español -y el art. 26 CP nicaragüense-). Por tanto, la efectiva conciencia de la antijuridicidad o del injusto, de la ilicitud del hecho, o, mejor, la ausencia de un error sobre la ilicitud, es una conditio sine qua non de la plena culpabilidad"; DE LA CUESTA AGUADO, Conocimiento de la ilicitud. Aproximación al conocimiento de la antijuridicidad del hecho desde las teorías psicológicas del pensamiento intuitivo, Dykinson, Madrid, 2007, 75.

60 Hace esta advertencia en relación con la regulación del error de prohibición en el CP español, DÍAZ Y GARCÍA CONLLEDO, en: LH Torío, 1999, 351 s., para concluir que, aunque en el lenguaje vulgar los términos "error" e "ignorancia" no son términos equivalentes, en Derecho sí es tradicional la equiparación entre ambas situaciones.

61 Vid., para más detalles, por todos, COBO DEL ROSAL/VIVES ANTÓN, PG, 5a, 1999, 672, 678; NIETO MARTÍN, El conocimiento del Derecho. Un estudio sobre la vencibilidad del error de prohibición, Atelier, Barcelona, 1999, 92 ss., 99 ss.; BERDUGO GÓMEZ DE LA TORRE/ARROYO ZAPATERO/FERRÉ OLIVÉ/ GARCÍA RIVAS/SERRANO PIEDECASAS/TERRADILLOS BASOCO, PG, 2004, 343 s.; CEREZO MIR, PG, III/2, 2004, 114, 126; ROXIN, AT, I, 4a , 2006, 932 ss. (= PG, I, 1997, 866 ss.); DE LA CUESTA AGUADO, Conocimiento de la ilicitud, 2007, 52 ss.; MUÑOZ CONDE/GARCÍA ARÁN, PG, 7ª 2007, 282; QUINTERO 
conocimiento no es suficiente para afirmar la plena culpabilidad del sujeto, ya que para que la norma penal pueda cumplir realmente su finalidad preventivogeneral, de motivación al ciudadano para que se abstenga de cometer hechos injustos, es preciso que el sujeto conozca la prohibición penal de la conducta ${ }^{62}$. Sin llegar a esta solución, en la doctrina española se defiende una postura intermedia, según la cual resulta suficiente con que el sujeto tenga conocimiento de la antijuridicidad o prohibición general de su conducta para que se encuentre en una situación apta para ser motivado por las normas jurídicas, para que se abstenga de realizar la conducta prohibida o para que realice la conducta impuesta por dichas normas jurídicas. Ahora bien, de esta interpretación no se debe deducir que el error de prohibición penal sea irrelevante; al contrario, puede reconocerse algún efecto atenuatorio a este error, pues la capacidad de motivación del sujeto puede ser diferente según que la prohibición sea general o específicamente penal, ya que tal diferente gravedad en la antijuridicidad también ha de tener reflejo en la capacidad motivadora de la norma y de la culpabilidad del sujeto (si la prohibición es penal se presume que la conducta es más grave, por lo que lo razonable es que el sujeto tenga mayores motivos para abstenerse de realizarla, mientras que si la prohibición es general la lesividad de la conducta no es percibida tan claramente, o el ciudadano no percibe su gravedad, por lo que no reconoce tan claramente la trascendencia de su incumplimiento) ${ }^{63}$.

OLIVARES, PG, 2 a $, 2007,441$.

62 Defiende esta tesis en la doctrina española, entre otros, BACIGALUPO ZAPATER, PG, 5a , 1998, 307 ss.; FELIP I SABORIT, Error iuris. El conocimiento de la antijuridicidad y el art. 14 del Código penal, Atelier, 2000, 126 ss., 147 s., 257; ARIAS EIBE, Error en DP, 2007, 135; DÍEZ RIPOLLÉS, PG, 2007, 427; MIR PUIG, PG, 8, 2008, 553.

63 Defienden esta tesis intermedia en la doctrina española, entre otros, LUZÓN PEÑA, en: EJB, II, 1995, 2843; PG, I, 1996, 462 s.; en: EPB, 2002, 662, para quien parece razonable no eximir por inculpabilidad en el caso de error invencible sobre la prohibición penal, pues pese a todo el sujeto sabe que la conducta está prohibida por el Derecho, por lo que no está excluida o totalmente perturbada su capacidad de motivación normal por la norma, pero la posibilidad de determinación normal sí es menor al no conocer la gravedad de la prohibición y la conminación penal de la misma, por lo que cabe apreciar una disminución de la culpabilidad recurriendo a la atenuante anológica en el error de prohibición penal, atenuante que según las circunstancias podría considerarse como muy cualificada (con los efectos en la determinación de la pena, según lo dispuesto en el art. $66.1 .1^{\mathrm{a}}$ y $2^{\mathrm{a}} \mathrm{CP}$ español, precepto similar al art. 78.1.c y d CP nicaragüense); DÍAZ Y GARCÍA CONLLEDO, en: LH Casabó, I, 1997, 674 s. [= en: LUZÓN PEÑA/MIR PUIG (Coords.), Cuestiones actuales de la teoría del delito, 1999,78 s.]; en: LH Torío, 1999, 356 s.; en: LH Roxin (2002), 79 s.; Error elementos normativos del tipo, 2007, 163 ss., quien reconoce que el error sobre la prohibición penal afecta a la culpabilidad del sujeto aunque no la excluye (coincidiendo con la explicación ofrecida por LUZÓN PEÑA), y esta relevancia puede traducirse en una menor punición dentro del marco penal del delito de que se trate, e incluso rebasando el límite inferior de éste acudiendo a la atenuante analógica que puede llegar a ser muy cualificada, coincidiendo en esto también con la postura de su maestro el prof. LUZÓN PEÑA. Y para DÍAZ Y GARCÍA CONLLEDO lo más acertado en el tratamiento del error de prohibición penal es combinar ambas cosas: es decir, no acudiendo necesariamente siempre a la atenuante analógica y desde luego no siempre a la atenuante muy cualificada, convirtiendo la atenuación en caso de error sobre la prohibición penal en potestativa. El error de prohibición penal puede plantearse a través del error sobre la existencia o alcance de una causa de atipicidad penal, por ejemplo, sobre el alcance del principio de insignificancia como causa de atipicidad penal, porque el sujeto cree que la conducta es injusta pero no suficientemente grave como para merecer la sanción penal; OLAIZOLA NOGALES, Error de prohibición, 2007, 61 ss., 65, quien sigue 
Como se ha advertido en líneas atrás, el CP nicaragüense no se pronuncia sobre esta cuestión, utilizando (a semejanza del CP español) un concepto lo suficientemente amplio y ambiguo, "error sobre la ilicitud del hecho", o "error sobre la prohibición del hecho" para el caso de error vencible, como para permitir todas las posturas doctrinales anteriormente mencionadas, excluyendo tan solo aquellas opiniones tradicionales que consideraban suficiente para la existencia del conocimiento de la antijuridicidad con el conocimiento de la dañosidad moral o social de la conducta $^{64}$.

\section{Otra de las cuestiones que recibela atención de la doctrina en el estudio del error de prohibición es la relativa a los criterios que han de ser valorados para decidir sobre su vencibilidad o invencibilidad. En elCP nicaragüense, a semejanza de los restantes $\mathrm{CP}$ europeos e iberoamericanos, no se ha considerado oportuno incluir en la regulación de esta clase de error una mención expresa de los criterios a tener en cuenta para la distinción entre la vencibilidad o invencibilidad del error de prohibición, dejando abierta la cuestión a la discusión doctrinal y jurisprudencial ${ }^{65}$.}

sustancialmente la propuesta interpretativa de LUZÓN PEÑA y DÍAZ Y GARCÍA CONLLEDO. En contra de la interpretación de estos autores, CEREZO MIR, PG, III/2, 2004, 126, ya que, en su opinión, no se puede aplicar la atenuante por analogía, porque en el CP español la aplicación de dicha atenuante requiere, en primer lugar, que se trate de una circunstancia que determine una menor gravedad del injusto o de la culpabilidad (lo que se podría dar en este caso de error sobre la prohibición penal), y en segundo lugar, que se trate de una circunstancia que obedezca a la misma ratio de las atenuantes reguladas expresamente en el citado texto legal (en el art. 21 CP español, precepto en el que se incluye el catálogo de las circunstancias atenuantes), y sucede que el error de prohibición no está comprendido en el concepto legal de circunstancia (se regula en el art. 14.3, y no en el art. $21 \mathrm{CP}$ español). De todas formas, este autor sí admite que en el error de prohibición penal puede haber una disminución de la culpabilidad del sujeto, y tal circunstancia habrá de ser tenida en cuenta en la medición de la pena (a través del art. $66 \mathrm{CP}$ español, precepto que es similar al art. $78 \mathrm{CP}$ nicaragüense). Con independencia de la corrección o incorrección del argumento alegado por CEREZO MIR, hemos de advertir que el mismo no tiene virtualidad en el CP nicaragüense, ya que se ha reconocido expresamente la analogía in bonam partem como posible fuente del DP nicaragüense (art. 10.2 CP nicaragüense), por lo que su aplicación no va a limitarse a la circunstancia atenuante por analogía (art. 35.9 CP nicaragüense, si bien es preciso advertir también que la regulación de la atenuante por analogía en el CP nicaragüense es más amplia que la regulación del CP español, ya que la analogía puede ir referida a las circunstancias atenuantes reguladas en el citado art. 35, o por peculiares condiciones personales del sujeto activo del delito o de su ambiente).

64 Reconoce esta amplitud interpretativa respecto del término "ilicitud" en el CP español, interpretación que puede hacerse extensiva al PCP nicaragüense, DÍAZ Y GARCÍA CONLLEDO, en: LH Torío, 1999, 356; en: LH Roxin (Lisboa), 2002, 79, si bien advierte este autor que el término "ilicitud" parece hacer referencia a la ilicitud general, ya que si se hubiera querido exigir el conocimiento de la prohibición penal se podía haber utilizado otra terminología menos ambigua, como por ejemplo "ilicitud penal", "contrariedad al Derecho penal", o "error sobre el carácter de delito o falta"; Error elementos normativos del tipo, 2007, $162 \mathrm{~s}$.

65 Tal decisión debe ser valorada positivamente, ya que no debe olvidarse que el error de prohibición es un elemento de la culpabilidad, y, en consecuencia, la comprobación de si concurre o no tal error y, en caso afirmativo, de si el mismo es vencible o invencible, ha de depender necesariamente de las circunstancias personales del sujeto que incurre en tal error, por lo que no se pueden establecer criterios generales en esta materia. Sobre esta cuestión, como ya se ha mencionado anteriormente, DÍAZ Y GARCÍA CONLLEDO, en: LH Torío, 1999, 359 ss.; Error elementos normativos del tipo, 2007, 174 s., estima que la tendencia debe ser apreciar con mayor generosidad el error invencible de prohibición teniendo en cuenta que nos encontramos ante un Derecho propio de sociedades complejas, con sistemas jurídicos cuyos mandatos en ciertos ámbitos son cada vez menos evidentes para los ciudadanos porque su conocimiento no se deriva sin más del conocimiento de los hechos o de la socialización normal del sujeto. Por tal motivo propone una normativización de los criterios sobre la vencibilidad e invencibilidad 
A mero título indicativo cabe apuntar que en la valoración de la evitabilidad o no del error de prohibición cobrará especial importancia la capacidad intelectual y el nivel de instrucción del sujeto, la clase de actividad que éste se dispone a realizar, si la misma implica daño o lesividad para los intereses de otras personas, si es una actividad sometida a una regulación específica, si se trata de una conducta que se enmarca en la actividad profesional que el sujeto desempeña, si en el ejercicio de esta actividad tiene a su disposición un gabinete jurídico y de asesoramiento..., sin olvidar que en esta valoración adquieren especial relevancia los deberes de reflexión y, sobre todo, de información sobre el Derecho vigente ${ }^{66}$.

Si bien se acaba de afirmar que en la regulación del error de prohibición el CP nicaragüense no establece ningún criterio en la valoración de la evitabilidad o no de este error, es preciso advertir que en otros preceptos de este Cuerpo legislativo se pueden hallar algunos indicios que pueden ser de gran utilidad en el tratamiento de esta materia. Se trata del reconocimiento expreso de diferencias culturales y sociales entre la población nicaragüense, atendiendo a dos circunstancias diferentes radicalmente entre sí: por una parte, se reconoce la existencia de costumbres diferenciadas entre la población nicaragüense, en particular de los pueblos indígenas o de las comunidades étnicas de la Costa Atlántica. Este Derecho consuetudinario puede entrar en conflicto con el Derecho "general o común", lo que puede provocar que el ciudadano indígena o habitante de la Costa Atlántica desconozca la prohibición general de su conducta cuando realiza un comportamiento conforme a sus costumbres. En tal caso se reconoce bajo determinadas circunstancias la prioridad del Derecho consuetudinario sobre el Derecho general (art. 20 CP nicaragüense: se aplicará el Derecho consuetudinario cuando el delito o la falta cometida tenga establecida una pena que no supere los cinco años de prisión), pudiendo recurrirse en los demás supuestos, y en particular cuando el Derecho consuetudinario entre en conflicto con la Constitución Política, a la regulación del error de prohibición, y podría admitirse con más facilidad la invencibilidad del mismo.

del error de prohibición, admitiendo, con carácter general, el planteamiento de ROXIN, AT, I, 4ª , 2006, 944 ss: (= PG, I, 1997, 878 ss.), sobre esta delimitación. Admite esta propuesta interpretativa sobre la flexibilización en el tratamiento del error invencible de prohibición, OLAIZOLA NOGALES, Error de prohibición, 2007, 42 ss.

66 Para más detalles sobre los criterios a tener en cuenta para valorar la vencibilidad o invencibilidad del error de prohibición, por todos, BACIGALUPO ZAPATER, PG, 5 , 1998, 316 ss.; NIETO MARTÍN, El conocimiento del Derecho, 1999, 107-215, con amplias referencias doctrinales; ZUGALDÍA ESPINAR, en: ZUGALDÍA ESPINAR (dir.)/PÉREZ ALONSO (coord.), PG, 2a , 2004, 620 ss.; ARIAS EIBE, Error en DP, 2007, 98 ss.; DÍEZ RIPOLLÉS, PG, 2007, 428; MUÑóZ CONDE/GARCÍA ARÁN, PG, 7ª , 2007, 385 s.; OLAIZOLA NOGALES, Error de prohibición, 2007, 155-199. 


\section{Revisla de Derecho}

La segunda circunstancia que alude a las diferencias sociales y culturales entre los ciudadanos nicaragüenses tiene su reconocimiento en la atenuante de escaso discernimiento o instrucción (art. 35.6 CP nicaragüense). Estas circunstancias personales tienen una importancia trascendental en la valoración del error de prohibición, ya que la falta de instrucción o las limitaciones en la capacidad de discernimiento facilitarán, en primer lugar, que el sujeto carezca del conocimiento de la antijuridicidad y, en segundo lugar, disminuirán la eficacia de los deberes de reflexión y, sobre todo, de información a la hora de valorar la evitabilidad o no del error sufrido.

Para finalizar con el comentario a este art. $26 \mathrm{CP}$ nicaragüense resulta oportuno hacer una breve referencia en torno al tratamiento de la conciencia eventual de la antijuridicidad (utilizando una terminología muy similar a la empleada para el dolo eventual). Es decir, de los casos en los que el sujeto tiene dudas sobre la valoración jurídica de la conducta que se dispone a realizar, no sabe con certeza que tal conducta está prohibida, pero es consciente de tal posibilidad o probabilidad. Tales supuestos no pueden tratarse como auténticos errores de prohibición, porque el sujeto no carece de conocimiento de la antijuridicidad de su conducta (no se equivoca sobre la antijuridicidad o ignora la prohibición), pero tampoco han de ser asimilados, al menos de forma automática y sin excepciones, a los supuestos de conocimiento de la prohibición general. No puede darse en este lugar una solución definitiva y clara sobre el tratamiento de la conciencia eventual de la antijuridicidad, tan solo cabe aventurar la posibilidad de eximir de responsabilidad penal en algunos casos de dudas sobre la antijuridicidad, y a tal solución puede llegarse por varías vías en el CP nicaragüense: bien recurriendo a la analogía con la regulación del error de prohibición, bien recurriendo al principio de inexigibilidad individual (regulado como eximente en el art. 34.10 CP nicaragüense) $)^{67}$.

\section{Supuestos de error problemáticos y/o sin regulación positiva}

Pese a la loable decisión del legislador nicaragüense de ofrecer una amplia regulación sobre el tratamiento del error en DP, siguen existiendo

67 Para más detalles sobre el tratamiento del conocimiento eventual sobre la antijuridicidad, vid., ampliamente, BACIGALUPO ZAPATER, PG, 5a , 1998, 308 s.; NIETO MARTÍN, El conocimiento del Derecho, 1999, $217-$ 236; ZUGALDÍA ESPINAR, en: COBO DEL ROSAL (dir.), Comentarios CP, I, 1999, 707; en: ZUGALDÍA ESPINAR (dir.)/PÉREZ ALONSO (coord.), PG, 2a , 2004, 624 s.; ROXIN, AT, I, 4ª 2006, 941 ss. (= PG, I, 1997, 874 ss.); DÍEZ RIPOLLÉS, PG, 2007, 426 s.; OLAIZOLA NOGALES, Error de prohibición, 2007, 68 ss., 80 SS. 
algunos supuestos de error que, o no tienen regulación positiva, o tal regulación sí se ha producido pero dejando abierta a la discusión doctrinal y jurisprudencial la decisión de su tratamiento como un error de tipo o un error de prohibición.

Tal omisión ha de ser valorada, en términos generales, positivamente, y ello por varias razones: en cuanto a los supuestos de error sí regulados, pero sobre los que existen discrepancias en su tratamiento como errores de tipo o como errores de prohibición, el silencio del legislador ha de aplaudirse, ya que no resulta conveniente que éste resuelva las posibles controversias dogmáticas y políticocriminales en su tratamiento antes de que se haya llegado a un mínimo consenso, optando por una de las teorías en detrimento de las demás. Y en los casos de ausencia de regulación, también la decisión es acertada, pues el error afecta a elementos sobre los que no reina acuerdo sobre su fundamentación y naturaleza, cuestión a resolver con carácter previo antes de plantear una eventual teoría del error sobre tales elementos.

De todas formas, los posibles efectos negativos de este silencio del legislador nicaragüense sobre algunos supuestos problemáticos de error se ven paliados por la regulación positiva de dos principios fundamentales en el establecimiento de límites a la potestad punitiva del Estado: los principios de responsabilidad subjetiva y de culpabilidad (art. $9 \mathrm{CP}$ nicaragüense), así como por el reconocimiento expreso de la analogía in bonam partem como fuente del Derecho Penal (art. 10.2 CP nicaragüense), permitiendo los primeros establecer límites a la responsabilidad penal, y favoreciendo la segunda la aplicación de eximentes o atenuantes en el tratamiento de tales errores por analogía con lo establecido en la regulación de los errores de tipo y de prohibición o, en general, con las circunstancias eximentes y atenuantes.

El primer supuesto problemático de error que no ha sido mencionado de forma expresa en los arts. 25 y 26 CP nicaragüense es el relativo al error (directo) sobre los presupuestos objetivos de las causas de justificación ${ }^{68}$,

68 Como ya se mencionara anteriormente, en el epígrafe relativo al error de prohibición, en el error (directo) sobre las causas de justificación se pueden distinguir tres supuestos diferentes: el error sobre los presupuestos objetivos de las causas de justificación, el error sobre los límites y el error sobre la existencia de las causas de justificación. Respecto de los dos últimos supuestos (error sobre los límites y sobre la existencia), no duda la doctrina en afirmar que nos encontramos ante dos variantes del error (indirecto) de prohibición. Ahora bien, como también se indicara con anterioridad, esta unanimidad doctrinal puede desaparecer si nos centramos en el error sobre los límites de las causas de justificación, y ello por la peculiaridad del CP nicaragüense que, al igual que el CP español, regula como atenuante muy cualificada la eximente incompleta (art. 35.1 CP nicaragüense), ya que ésta puede tener 

no así de los CP iberoamericanos ${ }^{69}$.

Como ejemplos de esta clase de error se suelen citar los siguientes: el sujeto X se aproxima a toda prisa con la mano levantada a V con la intención de preguntarle por una dirección o la hora, y V lo toma por un ladrón que está a punto de atacarle, por lo que dispara contra él (legítima defensa putativa); o el sujeto $\mathrm{X}$ interrumpe un servicio de culto religioso porque cree que se ha declarado un incendio en el pueblo (estado de necesidad putativo); o el sujeto $\mathrm{X}$ detiene erróneamente al sujeto $\mathrm{V}$ por creer que éste está cometiendo un delito (derecho de detención por particular putativo $)^{70}$.

En el tratamiento del error directo sobre la concurrencia en el hecho de los presupuestos objetivos de una causa de justificación se han propuesto diferentes posturas doctrinales, con diferencias sustanciales en el tratamiento del error vencible, la participación, la tentativa, la omisión, los deberes de tolerancia de la acción del autor (sobre posibles restricciones a la aplicación o no de la legítima defensa.... ${ }^{71}$ :

alguna incidencia en el tratamiento del error sobre los límites de las causas de justificación cuando tal error afecta al alcance de los requisitos o presupuestos inesenciales de la eximente, concurriendo los presupuestos o requisitos esenciales. Para más detalles sobre la definición y tratamiento del error directo sobre los límites de una causa de justificación, LUZÓN PEÑA, PG, I, 1996, 482 ss.; TRAPERO BARREALES, El error en las causas de justificación, 2004, 481 ss., 518 ss.

69 El error sobre los presupuestos de las causas de justificación sí se regula en algunos CP europeos, como el StGB austríaco (§ 3), admitiendo que el error vencible excluye la responsabilidad por el delito doloso y deja subsistente, en su caso, la responsabilidad por el delito imprudente. Y también se regula en algunos de los CP iberoamericanos: el CP brasileño, que incluye el error sobre las eximentes putativas en el error sobre los elementos del tipo (art. 20); el CP colombiano, en el que se incluye el error sobre las causas de justificación en la regulación del error de hecho (art. 34); en el CP de Costa Rica, en el que se incluye en las reglas del error de hecho el error sobre las circunstancias que justificarían el hecho realizado (art. 34), si bien en el PCP de 1998 se ha propuesto una regulación del error sobre las causas de justificación diferente, al incluirse expresamente en la regulación del error de prohibición (art. 32 PCP); el CP mexicano regula el error sobre las causas de justificación siguiendo, eso parece al menos, la teoría estricta de la culpabilidad (art. 15VIIIB). En otros CP de Derecho comparado se omite cualquier referencia al error sobre las causas de justificación en la regulación del error de tipo y de prohibición: así, por ejemplo, en los CP alemán ( $\S 16$ y 17), español (art. 14), peruano (art. 14) y portugués (arts. 16 y 17). Como se ha expuesto en el texto, la decisión del legislador nicaragüense de no regular específicamente esta clase de error ha de ser valorada positivamente, ya que el tratamiento del error en las causas de justificación sigue siendo uno de los temas más polémicos en la doctrina, por las implicaciones dogmáticas y políticocriminales que esta clase de error provoca. Por otro lado, para resolver definitivamente la discusión sobre el tratamiento de este error sería preciso que el legislador tomase partido claramente por una de las teorías planteadas, no resultando suficiente con que se regulara el efecto de tal error en la exclusión o no del dolo. Así, por ejemplo, en los CP austríaco, brasileño, colombiano y costarricense, se ha optado por tratar el error sobre las causas de justificación según las reglas del error de tipo, pero esta regulación no acaba con las discusiones en el tratamiento de este error, ya que seguirá debatiéndose qué teoría ha sido adoptada en esta regulación, si las teorías del dolo o alguna de las teorías limitadas de la culpabilidad, con las consecuencias que de ello se van a derivar en materia de participación, tentativa, omisión, protección o no de la persona que sufre los efectos del error a través de la legítima defensa..., hasta la responsabilidad civil derivada del hecho cometido al amparo de una causa de justificación putativa.

70 Los ejemplos han sido planteados por ROXIN, AT, I, 4 , 2006, 622 (= PG, I, 1997, 579).

71 Para una exposición resumida sobre las diferentes teorías, vid., LUZÓN PEÑA, en: EJB, II, 1995, 2845 ss.; PG, 
- Las teorías del dolo: partiendo de la consideración de que el dolo, concebido como dolo subjetivamente malo, incluye tanto el conocimiento de la situación típica como el conocimiento de la antijuridicidad de la conducta, y que el error es el reverso del dolo, para estas teorías no plantea ninguna especialidad el tratamiento del error sobre los presupuestos objetivos de una causa de justificación: si el error es vencible, excluye el dolo y deja subsistente la responsabilidad penal, en su caso, por el delito imprudente, y si el error es invencible se excluye la responsabilidad penal por falta de dolo e imprudencia. Ahora bien, a partir de la regulación positiva del error en el CP nicaragüense (y lo mismo cabría señalar en el CP español), en el que se reconoce diferentes efectos al error de tipo y al error de prohibición, aunque se defienda la teoría estricta o limitada del dolo sí será necesario aclarar ante qué clase de error nos encontramos en el error sobre los presupuestos objetivos de una causa de justificación: porque si es un error de tipo se aplicará lo dispuesto en el art. 25 CP nicaragüense, por lo que sólo de forma excepcional se castigará el error vencible de tipo, mientras que si se considera que es una modalidad del error de prohibición, en tal caso se aplicará la regulación prevista en el art. $26 \mathrm{CP}$ nicaragüense, lo que significa que se va a castigar de forma generalizada la imprudencia de Derecho cometida a través del error vencible sobre la concurrencia de los presupuestos de una causa de justificación.

- La teoría estricta de la culpabilidad: se defiende fundamentalmente (aunque no sólo por ellos) por los partidarios de la teoría finalista, según la cual el error directo sobre los presupuestos de una causa de justificación constituye una modalidad más del error indirecto de prohibición (también denominado error de permisión): cuando el sujeto cree que concurren los presupuestos de una causa de justificación está suponiendo que actúa legítimamente, que su hecho es lícito, que no está prohibido. Este error deja intacto el dolo,

I, 1996, 469 ss.; en: EPB, 2002, 664 ss., y ampliamente en TRAPERO BARREALES, Error en las causas de justificación, 2004, 43-358, con exposición de los defensores de cada una de las teorías planteadas. La exposición que se va a realizar en el texto se centra en el error directo sobre la concurrencia en el hecho de los presupuestos objetivos de una causa de justificación, ya que ésta es la modalidad de error que ha ocupado la mayor atención de la doctrina. Pero resulta preciso advertir que en los CP español y nicaragüense aún se podría plantear otra modalidad del error sobre los presupuestos de las causas de justificación: cuando, concurriendo los requisitos esenciales de la correspondiente causa de justificación, el error recae sólo sobre los presupuestos o requisitos inesenciales, sobre la concurrencia de tales requisitos, no sobre su valoración jurídica. La posibilidad de distinguir esta otra modalidad de error sobre los presupuestos de las causas de justificación se apoyaría en la regulación de las eximentes incompletas en ambos textos legales (arts. 21.1 CP español y art. $35.1 \mathrm{CP}$ nicaragüense), pues puede que la eximente incompleta cobre relieve en la solución de estos supuestos. No se puede exponer aquí las distintas posibilidades interpretativas que podrían plantearse en la solución de esta segunda modalidad del error sobre los presupuestos de las causas de justificación. Para más detalles me remito a lo expuesto en TRAPERO BARREALES, Op. cit., 359 ss. 
concebido como dolo natural, pues el sujeto tiene conocimiento de todos los elementos constitutivos del tipo penal (entendido como tipo indiciario), pero cree que su conducta no está prohibida al creerse amparado por una causa de justificación, ya que supone erróneamente que concurren los presupuestos objetivos de la causa de justificación reconocida por el ordenamiento jurídico (y con esa misma extensión que el sujeto se ha representado). Si el error es vencible, la culpabilidad del sujeto se verá atenuada, y si el error es invencible, la culpabilidad del sujeto estará excluida, pero en todo caso queda intacto el hecho injusto cometido dolosamente por él.

- La teoría restringida o limitada de la culpabilidad: esta tesis es la mayoritaria en Alemania y defendida por un amplio sector doctrinal en España ${ }^{72}$. Según esta concepción, el error de

72 Un sector de la doctrina española ha entendido que la terminología empleada en la redacción del error en el art. 14 CP español favorece la inclusión del error sobre los presupuestos objetivos de una causa de justificación en las reglas del error de tipo. Y esta misma conclusión puede hacerse extensiva a la interpretación de la regulación del error en el CP nicaragüense. En este sentido, MIR PUIG, en: COBO DEL ROSAL (dir.), Comentarios CP, I, 1999, 675 s.; PG, 8 $8^{\text {a }, ~ 2008, ~} 269$ ss., 422 ss., 551, 557, propone la siguiente argumentación: el apartado $\mathrm{n}^{\mathrm{o}} 3$ del art. 14 CP español (o el art. $26 \mathrm{CP}$ nicaragüense), se refiere a los casos de error que supongan desconocimiento de que el Derecho considera ilícito el hecho constitutivo de la infracción penal. "Pero quien actúa creyendo erróneamente que es objeto de una agresión de la que necesita defenderse lesionando al supuesto agresor no tiene, por esto sólo, que desconocer que es ilícito el hecho constitutivo de la infracción que objetivamente realiza (lesionar a quien de hecho no agredía); este sujeto yerra sobre un hecho constitutivo de la infracción penal, es decir comete un error de tipo. La ausencia de una agresión fundamentadora de la legítima defensa constituye un hecho necesario para la presencia de la infracción penal completa, en el sentido de concreta infracción de una norma penal que deja de existir cuando concurre una causa de justificación que permite el hecho. El supuesto de hecho completo de la concreta norma prohibitiva requiere una situación fáctica que no sólo realice la tipicidad abstracta del hecho, sino que no esté integrada por hechos -como determinadas agresiones- que lo justifiquen. Los presupuestos objetivos de una causa de justificación dan lugar a una situación fáctica distinta de la prohibida por la norma concreta. El hecho concretamente prohibido no se agota en la parte de situación descrita en el tipo del delito, sino que comprende también la ausencia en dicha situación de los hechos que dan lugar a una causa de justificación". En definitiva, para MIR PUIG, el error sobre los presupuestos objetivos de una causa de justificación recae sobre un hecho constitutivo de la infracción penal, y como hechos constitutivos de la infracción penal deben incluirse tanto los elementos descriptivos como los normativos de las causas de justificación. A la misma conclusión, considerar que el error directo sobre los presupuestos objetivos de una causa de justificación es un error de tipo, se puede llegar desde la teoría de los elementos negativos del tipo, interpretando la redacción de los arts. 14.1 CP español y $25 \mathrm{CP}$ nicaragüense desde los planteamientos de esta teoría. Desde esta perspectiva, y en relación con el Derecho español, por ejemplo, LUZÓN PEÑA, en: EJB, II, 1995, 2847; PG, I, 1996, 474; en: EPB, 2002, 666; y DÍAZ Y GARCÍA CONLLEDO, en: LH Valle Muñiz, 2000, 224 ss.; Error elementos normativos del tipo, 2007, 169 s. n. 27; OLAIZOLA NOGALES, Error de prohibición, 2007, 114 s., ponen de relieve la posibilidad de interpretar los términos "infracción penal", o "hecho constitutivo de la infracción penal" en el sentido de error sobre los elementos del tipo, entendiendo el término tipo como tipo global de injusto, abarcando, por tanto, tanto los errores sobre el tipo positivo como sobre el tipo negativo. Otros autores como ZUGALDÍA ESPINAR, en: COBO DEL ROSAL (dir.), Comentarios CP, I, 1999, 692 s., han reconocido que el art. 14 CP español, y lo mismo podría hacerse extensivo a los arts. 25 y $26 \mathrm{CP}$ nicaragüense, puede interpretarse desde los planteamientos de la teoría limitada de la culpabilidad o desde la teoría de los elementos negativos del tipo, si bien descarta tal exégesis atendiendo principalmente a consideraciones de política criminal, optando finalmente por la teoría estricta de la culpabilidad. Los argumentos que esgrime este autor son, en concreto, los siguientes: en primer lugar, porque en su opinión el legislador ha unificado todos los supuestos en los que el autor ha obrado con error sobre la ilicitud del hecho; en segundo lugar, porque se producirían injustificados vacíos de punibilidad en el error vencible, dada la incriminación excepcional de los delitos imprudentes en el CP español (argumento que también es extensivo al CP nicaragüense); en tercer lugar, porque la atenuación obligatoria de la pena en el error vencible de prohibición lleva a resultados igual de justos y con el mismo efecto preventivo que los que se obtienen con la teoría limitada de la culpabilidad; en cuarto lugar, porque la aplicación de la teoría de los elementos negativos del tipo impide 
prohibición ha de ser tratado según los planteamientos de la teoría de la culpabilidad: este error no excluye el dolo, sino que afecta únicamente a la culpabilidad del sujeto, atenuándola o excluyéndola según que el error sobre la antijuridicidad del hecho cometido sea vencible o invencible. Ahora bien, a diferencia de la teoría estricta de la culpabilidad, el error directo sobre la concurrencia en el hecho de los presupuestos objetivos de una causa de justificación no es un error de prohibición o, al menos, no debe ser tratado como tal, sino que es un error de tipo o, al menos, debe ser tratado como un error de tipo: si el error es vencible, se excluye el dolo y dará lugar, en su caso, a responsabilidad penal por el delito imprudente, y si el error es invencible, se excluye toda responsabilidad penal por ausencia de dolo e imprudencia.

Son varias las versiones doctrinales englobadas bajo la genérica denominación de la teoría restringida o limitada de la culpabilidad. Las principales son: la teoría restringida de la culpabilidad por aplicación analógica de las reglas del error de tipo y la teoría restringida de la culpabilidad defendida por la teoría de los elementos negativos del tipo ${ }^{73}$ :

\section{- La teoría restringida de la culpabilidad por analogía con} el error de tipo: los autores que defienden esta tesis entienden que la regulación contenida en el § 16 StGB alemán, y en el art. 14.1 CP español, y lo mismo podrá plantearse desde la perspectiva del art. $25 \mathrm{CP}$ nicaragüense, se refiere al error de tipo, entendido el concepto tipo como tipo indiciario o en sentido estricto. Ahora bien, el error sobre los presupuestos objetivos de una causa de

el castigo del partícipe que actúa sin error, porque el hecho del autor es atípico o, todo lo más, dará lugar a responsabilidad por un delito imprudente; y en quinto lugar, porque se impide actuar en legítima defensa al que es víctima del error ajeno y sólo puede alegar estado de necesidad para proteger los bienes jurídicos que son puestos en peligro por el error de otro. Con ser ciertas las consecuencias político criminales destacadas por ZUGALDÍA ESPINAR, también desde la teoría de los elementos negativos del tipo se proponen soluciones a prácticamente todas ellas, con la única excepción de lograr resolver la impunidad del error vencible de tipo si el legislador penal ha optado por no incriminar la comisión imprudente en esa modalidad delictiva -pero se trata de la misma consecuencia que se deriva en general del error de tipo vencible cuando el error recae sobre los elementos del tipo indiciario o tipo positivo-. Sobre los distintos argumentos esgrimidos en contra de la teoría de los elementos negativos del tipo, tanto dogmáticos como político criminales, ampliamente en TRAPERO BARREALES, El error en las causas de justificación, 2004, 237 ss., 276 ss.

73 Otras posturas doctrinales sobre el tratamiento de esta clase de error son, entre las propuestas por ROXIN, AT, I, 4, 2006, 630 ss. (= PG, I, 1997, 581 s.), la teoría de la culpabilidad que remite a las consecuencias jurídicas del error de tipo, la teoría de la culpabilidad dependiente (de la pena del delito imprudente) y la teoría de la culpabilidad independiente en cuanto a las consecuencias (porque se trata de un error de prohibición, pero el tratamiento de este error se desliga de lo dispuesto en el $§ 17$ StGB alemán, porque la atenuación de la pena ha de ser obligatoria, recurriendo para ello a lo dispuesto en el $\$ 49 \mathrm{StGB}$ ). Para más detalles sobre estas teorías, vid., por todos, TRAPERO BARREALES, El error en las causas de justificación, 2004, 148 ss., 298 ss. 
justificación se parece al error de tipo porque, al igual que en éste, el sujeto se equivoca sobre la situación objetiva en la que se dispone a actuar, a diferencia del error de prohibición en el que el sujeto tiene conocimiento exacto de la situación objetiva y simplemente se equivoca sobre la licitud o ilicitud de su conducta. En el error sobre los presupuestos objetivos de una causa de justificación el sujeto se representa una situación que, de ser cierta, de concurrir realmente, convertiría su conducta en lícita, en fiel a Derecho, igual que sucede en el error de tipo, en que si la situación representada por el sujeto fuera cierta, si concurriera realmente, convertiría su conducta en lícita, o al menos no sería penalmente antijurídica. Por el contrario, en el error de prohibición el sujeto tiene un conocimiento exacto de la situación objetiva, simplemente se equivoca sobre la licitud de dicha conducta, y no puede producirse en ningún caso una coincidencia entre representación subjetiva y realidad objetiva, el sujeto no actúa fiel a Derecho (la única forma de actuación fiel a Derecho en estos casos pasa por una reforma legislativa que destipifique esa conducta como delictiva). En el error sobre los presupuestos de una causa de justificación lo que el sujeto quiere es jurídicamente lícito, en el error de prohibición lo que el sujeto quiere es contrario a lo que desea el Derecho $^{74}$.

Esta versión de la teoría restringida de la culpabilidad que aplica analógicamente las reglas del error de tipo ha podido ser puesta en entredicho en el DP español a la vista de las dudas que plantean algunos autores sobre la admisión de la analogía in bonam partem fuera de la aplicación de las atenuantes por analogía (art. 21.6 $6^{\mathrm{a}} \mathrm{CP}$ español $)^{75}$, pero tales dudas están descartadas en el CP nicaragüense, dado que, como ya se ha mencionado con anterioridad, en este texto legal se reconoce expresamente la analogía a favor del reo (arts. 1.4 en sentido contrario y 10.2 CP nicaragüense).

- La teoría de los elementos negativos del tipo: parte esta tesis de la concepción del tipo como tipo global de injusto, distinguiendo entre tipo positivo, que se corresponde con el concepto de tipo

74 Así, como afirma MIR PUIG en: COBO DEL ROSAL (dir.), Comentarios CP, I, 1999, 671: “a diferencia de lo que sucede en el error de prohibición, el (error) que recae sobre los presupuestos típicos de una causa de justificación no supone desatención del deber de conocimiento del Derecho y no hace preciso, por tanto, mayor severidad con que se trata el desconocimiento del Derecho. Dicha mayor severidad sólo está justificada -si es que lo está- como estímulo a conocer el Derecho y para evitar que resulte beneficiado quien no se preocupa de conocer lo prohibido, en comparación con quien sí se ha tomado la molestia de tomar conocimiento de ello".

75 Es el caso, entre otros, de CEREZO MIR, PG, II, 6 ${ }^{\text {, }}$ 1998, 191, quien reconoce que la apreciación de causas de justificación por analogía no sería contrario al principio de legalidad, por tratarse de una analogía in bonam partem, pero no es posible apreciar eximentes por analogía a tenor de lo dispuesto en el art. $4.3^{\circ} \mathrm{CP}$ español. 


\section{Revisla de Derecho}

indiciario o en sentido estricto de la doctrina mayoritaria, y el tipo negativo, la ausencia de causas de justificación (y de atipicidad penal). Sólo cuando se realiza el tipo global de injusto y el sujeto abarca con su dolo todos los elementos del tipo global de injusto se está en presencia de un hecho desvalorado, antijurídico, respecto del cual es preciso exigir al sujeto el conocimiento de su antijuridicidad para poder afirmar su plena responsabilidad penal por el hecho injusto cometido. Para esta tesis los presupuestos objetivos de las causas de justificación son elementos del tipo (de la parte negativa), por lo que cualquier error sobre tales circunstancias ha de ser tratado como lo que es, un error de tipo: si la ausencia de los presupuestos de una causa de justificación es necesaria para que concurra el tipo negativo, y ésta, a su vez, para que se dé el tipo total de injusto (= tipo positivo + tipo negativo), la suposición errónea de que concurren aquellos presupuestos supone un error sobre el tipo negativo y, por tanto, relativo al tipo total de injusto: es un error de tipo ${ }^{76}$.

\section{El segundo supuesto de error sobre el que el CP nicaragüense guarda} silencio es el error sobre las circunstancias atenuantes (arts. 35 y $37 \mathrm{CP}$ nicaragüense)ysobrelos hechosocircunstancias delostipos privilegiados. Ejemplos de lo primero: el sujeto comete el hecho delictivo desconociendo que la víctima es un determinado pariente del autor, en aquellos casos en los que la circunstancia de parentesco actúa como atenuante (art. $37 \mathrm{CP}$ nicaragüense); o reconoce haber cometido el hecho delictivo sin darse cuenta de su confesión (art. 35.3 CP nicaragüense), o procede a reparar el daño causado sin ser consciente de ello (art. 35.5 CP nicaragüense), o comete el hecho bajo un estado de perturbación, aunque el sujeto no lo

76 Una postura muy parecida a la teoría de los elementos negativos del tipo es la que defiende MIR PUIG, en: COBO DEL ROSAL (dir.), Comentarios CP, I, 1999, 671 ss.; PG, 8a, 2008, 269 s., 422 ss., 551, 557, pues no admite la terminología/planteamiento de la teoría de los elementos negativos del tipo, pero acepta el fondo de su fundamentación. Utiliza este autor el término "tipo" en sentido clásico referido a la parte positiva del injusto penal, pero reconoce que para la presencia completa del hecho injusto es preciso que concurra una situación en la que no se den los presupuestos de una causa de justificación. Para MIR, el hecho típico justificado no es el mismo hecho que el no justificado: ambos no se diferencian sólo por ser valorados de forma distinta por el Derecho, sino que merecen dicha valoración distinta precisamente por suponer hechos situacionalmente distintos. La argumentación de MIR PUIG es la siguiente: el hecho penalmente antijurídico completo requiere la concurrencia de los elementos de la situación típica que fundamentan positivamente el injusto penal y la ausencia de los elementos propios de la situación típica de una causa de justificación: el supuesto de hecho tiene una parte positiva y una parte negativa, requiere el tipo del delito (o tipo positivo) y la ausencia del tipo de una causa de justificación (tipo negativo). El tipo negativo hace desaparecer el hecho antijurídico, dejando intacto el tipo positivo. De esta explicación concluye MIR que el error sobre el tipo positivo y el error sobre el tipo de una causa de justificación coinciden en su significado de ser errores sobre elementos situacionales del hecho injusto penal: ambas clases de errores afectan a una situación típica, la descrita en el tipo del delito y la descrita en el tipo de una causa de justificación. La suposición errónea de una causa de justificación no puede desplazar el dolo típico pero sí el carácter doloso del hecho antijurídico completo, que no sólo requiere un tipo doloso, sino también que el sujeto sepa que no concurre un tipo de justificación. 
haya percibido como tal al actuar (art. 35.2 CP nicaragüense). Ejemplos de lo segundo: el sujeto que coopera en un suicidio, desconociendo que el suicida había tomado la decisión de quitarse la vida (art. 142.2 y 3 $\mathrm{CP}$ nicaragüense), o causa la muerte de una persona con padecimientos insoportables o con una enfermedad incurable, desconociendo esta circunstancia y que la víctima desea morir (art. 142.4 CP nicaragüense), o el sujeto priva de libertad a otro, poniéndolo en libertad antes de que transcurran 48 horas de la detención, pero cree que ha transcurrido más tiempo (art. 163.2 CP nicaragüense).

También en el CP español se ha optado por la no regulación expresa del error sobre las circunstancias atenuantes y sobre los tipos privilegiados, lo que ha merecido las críticas de la doctrina, planteándose diversas soluciones para esta clase de error, y que por la semejanza en la regulación también podrían defenderse en el CP nicaragüense: en primer lugar, se podría proponer la aplicación de las reglas sobre la comunicabilidad de las circunstancias atenuantes previsto en el art. $77 \mathrm{CP}$ nicaragüense (precepto similar art. $65 \mathrm{CP}$ español), centrando tal interpretación sólo en las circunstancias atenuantes genéricas o extendiéndolo también a las circunstancias atenuantes específicas de los tipos privilegiados; en segundo lugar, se podría plantear la aplicación analógica de la regulación del error de tipo del art. $25 \mathrm{CP}$ nicaragüense (precepto idéntico al art. 14 CP español); y en tercer lugar, quizás la solución más acertada, se podría defender la solución del tratamiento del error diferenciada, teniendo en cuenta el fundamento y naturaleza de las circunstancias atenuantes y de los tipos privilegiados: así, si el fundamento de la atenuación se basa en un menor contenido de injusto (desvalor de acción y/o de resultado), sería necesario que el sujeto tuviera conocimiento de la concurrencia de tal circunstancia para su apreciación ${ }^{77}$; si el fundamento de la

$77 \quad$ Para el caso de error sobre los tipos privilegiados las soluciones que se han propuesto son variadas, pues junto al tipo privilegiado objetivamente concurrente también concurre el tipo básico, al menos ésta es la suposición del sujeto activo. En concreto, en el tratamiento del error sobre los tipos privilegiados se han propuesto las siguientes posturas doctrinales: en primer lugar, la apreciación del tipo privilegiado objetivamente concurrente; en segundo lugar, la apreciación de un concurso ideal entre el tipo privilegiado objetivamente concurrente y la tentativa del tipo básico; en tercer lugar, la apreciación del tipo básico consumado, teniendo en cuenta en la determinación judicial de la pena que se dan las circunstancias objetivas del tipo privilegiado; y en cuarto lugar, la apreciación de la tentativa del tipo básico sin más, y en quinto lugar, pudiendo compatibilizarse con alguna de las anteriores, valorar también la ratio de la circunstancia típica accidental, esto es, si afecta al tipo de injusto o afecta a la culpabilidad. Para más detalles sobre todas estas posturas doctrinales, por todos, BACIGALUPO ZAPATER, PG, 5ª 1998, 240; CEREZO MIR, PG, II, 6 a , 1998, 135; COBO DEL ROSAL/VIVES ANTÓN, PG, 5ª 1999 , 681; MAQUEDA ABREU, en: LH Cerezo, 2002, 856 ss.; CASTRO MORENO, El error sobre las circunstancias atenuantes (el error sobre las circunstancias atenuantes genéricas modificativas de la responsabilidad y sobre los elementos accidentales de los tipos privilegiados), Tirant lo Blanch, Valencia, 2003, 48 ss.; BERDUGO GÓMEZ DE LA TORRE/ARROYO ZAPATERO/FERRÉ OLIVÉ/GARCÍA RIVAS/SERRANO PIEDECASAS/ TERRADILLOS BASOCO, PG, 2004, 261; FLORES MENDOZA, El error sobre las circunstancias modificativas de la responsabilidad criminal en el ordenamiento jurídico español, Comares, Granada, 2004, 80 ss.; RAMOS 


\section{Revisla de Perecho}

atenuación de la pena se basa en una disminución de la culpabilidad sería necesario comprobar si tal atenuación se debe a una disminución de la imputabilidad del sujeto, en cuyo caso tal error sobre la atenuante sería irrelevante, ya que en este caso lo único decisivo es que la capacidad de culpabilidad esté disminuida por la anomalía psíquica o perturbación que padece (y la valoración que el sujeto haga o no de su capacidad de culpabilidad es irrelevante), pero si la atenuación se fundamenta en una disminución de la exigibilidad individual en este caso sí será necesario que el sujeto tenga conocimiento de las circunstancias que hacen surgir la atenuación de la culpabilidad, por lo que el error-desconocimiento sobre la concurrencia de tal circunstancia que disminuye la culpabilidad del sujeto daría lugar a su no apreciación; $y$, finalmente, si el fundamento de la disminución de la pena se debe a consideraciones de carácter políticocriminal, el tratamiento del error sobre tales circunstancias debería ser similar al error sobre los elementos que se incluyen bajo la categoría de la punibilidad ${ }^{78}$.

Ciertamente, a diferencia de las circunstancias agravantes y los tipos cualificados, que necesariamente han de fundamentarse en un mayor contenido de injusto (desvalor de acción y/o de resultado), las circunstancias atenuantes y tipos privilegiados pueden fundarse en una disminución del injusto, de la culpabilidad o en consideraciones de política criminal ajenas al injusto y a la culpabilidad del sujeto, por lo que no parecería muy acertado dar una solución uniforme al tratamiento del error sobre circunstancias tan hetereogéneas, cuando, entre otras cosas (como veremos a continuación), tampoco existe unanimidad en el tratamiento del error sobre la culpabilidad y sobre la punibilidad. Y como se ha destacado en el inicio de este apartado, la ausencia de regulación expresa de esta clase de error no puede ser censurada en el Derecho penal nicaragüense, en el que se reconoce expresamente como principios limitadores de la potestad punitiva del Estado a los principios de responsabilidad subjetiva y de culpabilidad, ya que a través de la aplicación de estos principios se podrán ofrecer soluciones satisfactorias al error sobre las atenuantes y sobre los tipos privilegiados.

TAPIA, en: ZUGALDÍA ESPINAR (dir.)/PÉREZ ALONSO (coord.), PG, 2a , 2004, 520 s.; ARIAS EIBE, Error en DP, 2007, 144 s., 163 ss.; DÍEZ RIPOLLÉS, PG, 2007, 176; MIR PUIG, PG, 8a , 2008, 273.

78 Vid., para más detalles sobre las distintas posturas doctrinales mencionadas en el texto, por todos, COBO DEL ROSAL/VIVES ANTÓN, PG, 5a , 1999, 681; MAQUEDA ABREU, en: LH Cerezo, 2002, 854 ss.; CASTRO MORENO, El error sobre las atenuantes, 2003, 19-60; FLORES MENDOZA, El error sobre las circunstancias, 2004, 62-106; RAMOS TAPIA, en: ZUGALDÍA ESPINAR (dir.)/PÉREZ ALONSO (coord.), PG, 2a , 2004, 520; ARIAS EIBE, Error en DP, 2007, 146 ss., 158 ss.; MIR PUIG, PG, $8^{\mathrm{a}}$, 2008, 273, 606. Una postura particular en torno al error sobre las circunstancias modificativas genéricas, en concreto respecto de aquellas que afectan al injusto (sean agravantes o sean atenuantes), DÍEZ RIPOLLÉS, PG, 2007, 439. 
Un tercer supuesto de error que no ha sido regulado de forma expresa es el relativo al error sobre las causas de exclusión de la culpabilidad, distinguiendo entre dos categorías, las causas de exclusión de la imputabilidad (la minoría de edad, las anomalías psíquicas, el trastorno mental transitorio, el estado de perturbación, y las alteraciones en la percepción desde el nacimiento o la infancia, arts. 33 y 34.1 a 3 CP nicaragüense), y las causas de exculpación (el miedo insuperable y la inexigibilidad individual, art. 34.6 y $10 \mathrm{CP}$ nicaragüense) $)^{79}$.

El error sobre estas eximentes ha suscitado escaso interés por parte de la doctrina, lo que ha podido ser una de las razones para la ausencia generalizada de regulación en los CP de Derecho comparado, aunque sí existe acuerdo en que el error sobre las causas de inimputabilidad ha de ser considerado irrelevante; si el sujeto sufre una anomalía psíquica que le impide motivarse por las normas jurídicas resulta totalmente irrelevante que tenga conocimiento o no de la enfermedad o anomalía que padece; y al revés, también resulta irrelevante la creencia equivocada del sujeto de que sufre una anomalía o alteración psíquica que anula su capacidad de culpabilidad, cuando ello no es asi ${ }^{80}$. Y también existe acuerdo en que el error sobre las causas de exculpación sí ha de ser relevante: porque si concurre la situación objetiva que sirve de base a una causa de exculpación, por ejemplo, la amenaza de un mal en el miedo insuperable, y el sujeto lo desconoce no podrá ser apreciada dicha eximente, ya que el sujeto ignora que en la situación objetiva en la que se encuentra no le sería exigible la actuación conforme a Derecho. Y a la inversa, si el sujeto cree erróneamente que concurren los presupuestos

79 No existe acuerdo en la doctrina sobre cuáles son en concreto las causas de exculpación, si bien se admite de forma generalizada que el miedo insuperable y la inexigibilidad individual (además del error invencible de prohibición) sí pertenecen a esta categoría. Así, y a mero título ejemplificativo, para CEREZO MIR, PG, II, 6a , 1998, 259 ss.; PG, III/2, 2004, 136 ss., las causas de inculpabilidad (o de exculpación) son: el estado de necesidad como causa de inculpabilidad (ya que en ocasiones el estado de necesidad es causa de justificación), el miedo insuperable y el encubrimiento entre parientes, tesis que es admitida por DÍEZ RIPOLLÉS, PG, 2007, 447 ss.; para BERDUGO GÓMEZ DE LA TORRE/ARROYO ZAPATERO/FERRÉ OLIVÉ/GARCÍA RIVAS/SERRANO PIEDECASAS/ TERRADILLOS BASOCO, PG, 2004, 348 ss.; y ZUGALDÍA ESPINAR, en: ZUGALDÍA ESPINAR (dir.)/ PÉREZ ALONSO (coord.), PG, 2 a , 2004, 657 ss., las causas de exulpación son el estado de necesidad exculpante y el miedo insuperable; para MUÑOZ CONDE/GARCÍAARÁN, PG, 7a , 2007, 386 ss., las causas de exculpación son la no exigibilidad de otra conducta, el estado de necesidad disculpante, el miedo insuperable y la delincuencia por convicción o por conciencia, mientras que el encubrimiento entre parientes "constituyen un puente entre las causas de exculpación y las excusas absolutorias” (p. 393); para COBO DEL ROSAL/VIVES ANTÓN, PG, 5ª 1999, 687 ss., 694 ss.; y MIR PUIG, PG, 8ª , 2008, 592 ss., las causas de exculpación son, el miedo insuperable, el estado de necesidad excusante (matizando MIR PUIG, ya que este autor recurre a la eximente analógica de estado de necesidad exculpante) y la inexigibilidad. Por su parte, eximentes como el estado de necesidad excluyente de la responsabilidad por el hecho, el miedo insuperable, la excusa absolutoria, entre otras, para BACIGALUPO ZAPATER, PG, 5a , 1998, 278 ss., 288 ss., pertenecen a la categoría la responsabilidad por el hecho, categoría intermedia entre la antijuridicidad y la culpabilidad.

80 V., más ampliamente, DÍEZ RIPOLLÉS, PG, 2007, 452; MIR PUIG, PG, 8 , 2008, 269, 606. 
objetivos de una causa de exculpación, por ejemplo, cree que sobre él se cierne la amenaza de un mal inminente, tal error sí ha de ser relevante, ya que el sujeto cree existente la situación que disculparía su proceder injusto, por lo que estaría en las mismas condiciones de inexigibilidad individual de la conducta conforme a Derecho que si los presupuestos objetivos de la causa de exculpación concurrieran realmente; en estos casos la controversia doctrinal se centra en cómo resolver este error sobre la concurrencia de los presupuestos de una causa de exculpación, si se debe recurrir a las reglas del error o, como parece más acertado, a la apreciación de la propia causa de exculpación ${ }^{81}$.

Pero el error sobre las causas de exclusión de la culpabilidad puede presentar otros aspectos interesantes, y que no han sido objeto de atención por parte de la doctrina. En particular, pueden surgir algunos problemas en la resolución de los supuestos de errores de tipo y, sobre todo, de prohibición, cometidos por personas que sufren una anomalía psíquica, ya que será necesario averiguar si tal error es una manifestación de la anomalía psíquica que padece el sujeto activo, y como tal debe ser tratado, o, por el contrario, si es realmente un problema de error, si bien cometido por una persona que padece una anomalía o alteración psíquica. Como demostración de lo que se acaba de afirmar nos puede servir el caso "El rey de los gatos" ("Katzenkönig”) juzgado en el BGH alemán (BGHst 15-9-1988) ${ }^{82}$ :

81 Vid., para más detalles sobre el error en las causas de exclusión de la culpabilidad, por todos, COBO DEL ROSAL/ VIVES ANTÓN, PG, 5a , 1999, 700; VARONA GÓMEZ, El miedo insuperable: una construcción de la eximente desde una teoría de la justicia, Comares, Granada, 2000, 188 ss.; ZUGALDÍA ESPINAR, en: ZUGALDÍA ESPINAR (dir.)/PÉREZ ALONSO (coord.), PG, 2a , 2004, 663; BUSTOS RAMÍREZ/HORMAZÁBAL MALARÉE, PG, 2a , 2006, 481, 486; MUÑOZ CONDE/GARCÍA ARÁN, PG, 7 , 2007, 389 s., 391; QUINTERO OLIVARES, PG, 2a , 2007, 442; MIR PUIG, PG, 8, 2008, 605 s. A otra opinión llega DÍEZ RIPOLLÉS, PG, 2007, 452 s., al considerar el error sobre los presupuestos de las causas de exculpación como irrelevantes, y el motivo de esta conclusión se debe a que falta una regulación positiva en torno a esta clase de error, ya que en un plano conceptual sí considera que el error sobre estas eximente puede ser relevante. Sobre el tratamiento del error en las causas de exculpación resulta oportuno mencionar que en el § 35.II StGB alemán se ha propuesto una regulación del error en el estado de necesidad disculpante, regulación que, en opinión de ROXIN, AT, I, 4ª , 2006, 508 (= PG, I, 1997, 485), enlaza con el tratamiento del error de prohibición.

82 El caso es el siguiente: el policía R vivía en compañía de otras dos personas, H y P. Aquel, debido a su carácter $\mathrm{y}$ a su amor imposible por $\mathrm{H}$, es muy influenciable. Al principio, sólo por diversión, $\mathrm{H}$ y $\mathrm{P}$ hicieron creer a $\mathrm{R}$ en un rey de los gatos que encarnaba el mal desde hacía miles de años y amenazaba con exterminar gran parte de la humanidad. Al enterarse $\mathrm{H}$ de que un ex-novio iba a casarse, en una mezcla de celos y odio decidió usar su poder de influencia sobre R para matar a la esposa de su antiguo novio, N. Para conseguir su propósito, H y P hicieron creer a $\mathrm{R}$ que el rey de los gatos exigía una víctima, $\mathrm{N}$, y que él era el elegido para matarla. Si R se negaba, sería condenado tras su muerte y el rey de los gatos exterminaría a millones de hombres. Como R se resistía a llevar a cabo la acción homicida, dadas sus creencias religiosas, ya que el hecho que H y P le proponían suponía atentar contra el quinto mandamiento, estos dos sujetos le explicaron que tal prohibición de matar no tenía vigencia en esta situación porque se trataba de un encargo divino con el que podía liberar a la humanidad. Finalmente, $\mathrm{H}$ y $\mathrm{P}$ convencieron a $\mathrm{R}$ y éste intentó matar a la víctima exigida por el rey de los gatos, N, si bien finalmente no lo consiguió. 
Y, para finalizar con este repaso a los supuestos que no han sido regulados en el CP nicaragüense, cabe mencionar en último lugar al error sobre la punibilidad. Estamos ante una de las categorías más discutidas en la dogmática penal, no sólo por la discusión sobre su pertenencia o no a la teoría general del delito, sino también por los supuestos o circunstancias que se engloban bajo la misma ${ }^{83}$. Entre estas circunstancias que se incluyen bajo la genérica categoría de la punibilidad se suele citar la denominada excusa absolutoria relativa a la exención de pena de determinados parientes próximos en los delitos contra el patrimonio (no regulada expresamente en el $\mathrm{CP}$ nicaragüense), o las causas personales de supresión o anulación de la punibilidad, como por ejemplo la regularización de la situación fiscal en los delitos tributarios (art. 309.4 CP nicaragüense). La falta de un mínimo consenso sobre esta categoría hace aconsejable la omisión de la regulación del error sobre la misma, dejando abierta a la discusión la relevancia o irrelevancia de este error, teniendo en cuenta el fundamento de la circunstancia, y valorando especialmente si se trata de un error sobre la circunstancia reconocida por el Derecho, bien porque el sujeto ignora que concurre tal circunstancia (lo que puede tener distinto efecto según sea una condición objetiva de punibilidad o una causa personal de exclusión de la punibilidad), bien porque el sujeto cree erróneamente que concurren los presupuestos o requisitos de tal circunstancia que afecta a la punibilidad. En todo caso, en el tratamiento del error sobre la punibilidad puede resultar útil la admisibilidad de la analogía in bonam partem ${ }^{84}$.

83 Para más detalles sobre el concepto, naturaleza y elementos de la punibilidad, LUZÓN PEÑA, en: EJB, IV, 1995, 5423 ss.; en: EPB, 2002, 1049 ss.; La punibilidad, en: LH Cerezo, 2002, 831 ss.

84 Vid., para más detalles sobre el tratamiento del error sobre la punibilidad, por todos, LUZÓN PEÑA, en: EJB, IV, 1995, 5429; en: EPB, 2002, 1056; en: LH Cerezo, 2003, 845. Entre los autores que sí admiten eficacia al error sobre la punibilidad, a menor título ejemplificativo, cabe mencionar a BACIGALUPO ZAPATER, PG, 5a , 1998, 308; ZUGALDÍA ESPINAR, en: COBO DEL ROSAL (dir.), Comentarios CP, I, 1999, 708; en: ZUGALDÍA ESPINAR (dir.)/PÉREZ ALONSO (coord.), PG, 2a , 2004, 610 s., quien sí admite el error sobre las excusas absolutorias, recurriendo para el tratamieto del mismo a la analogía con los supuestos de error de prohibición, ya que quien piensa que su conducta no es merecedora de pena actúa, en lo referente a su voluntaria y consciente oposición al Derecho, de forma virtualmente idéntica a quien lo hace con error sobre la ilicitud del hecho; MORENO-TORRES HERRERA, El error sobre la punibilidad, Tirant lo Blanch, Valencia, 2004, passim, y particularmente 97 ss., con amplias referencias doctrinales a favor y en contra de la admisión del error sobre la punibilidad. Esta autora también recurre a la analogía con el error de prohibición (art. 14.3 CP español): sea un error sobre condiciones objetivas de punibilidad, sea un error sobre causas personales de exclusión de la pena, y sea un error sobre los presupuestos de una de estas circunstancias, sea un error sobre la propia valoración de la punibilidad de la conducta; BUSTOS RAMÍREZ/HORMAZÁBAL MALARÉE, PG, 2a , 2006, 372 s., 479 s., para quienes la solución al error sobre las condiciones objetivas de punibilidad o a las excusas absolutorias vendría de la valoración de si respecto del sujeto que ha padecido tal error es innecesaria la pena, o no es necesaria en la magnitud prevista para la correspondiente figura delictiva, y argumentan que "si ya en el injusto el legislador consideró la necesidad de la pena a través de un criterio de utilidad, ciertamente debe tenerla en cuenta como criterio general al momento de hacer responder al sujeto por su hecho injusto y, por tanto, si a ese respecto había una creencia errónea del sujeto, tiene que hacerse cargo de ella". De otra opinión, en la doctrina alemana, ROXIN, AT, I, 4a , 2006, 508, 1046 (= PG, I, 1997, 485, 980), quien rechaza la aplicación de las reglas del error 


\section{El error inverso}

Para concluir este comentario en torno a la regulación del error en el CP nicaragüense sería necesario referirnos, siquiera de forma breve, a la otra manifestación del error de tipo y de prohibición, el error inverso.

Si centramos la atención en los supuestos menos problemáticos podemos definir el error inverso de tipo como la creencia errónea por parte del sujeto de que concurren los hechos constitutivos de la infracción penal (empleando la misma terminología del art. $25 \mathrm{CP}$ nicaragüense), mientras que el error inverso de prohibición consistirá en la creencia errónea de que un hecho justificado o penalmente irrelevante está prohibido por el DP. Ejemplo de lo primero, el sujeto dispara a una persona que acaba de morir minutos antes, creyendo que estaba dormida, o el sujeto se apodera de una cosa mueble creyendo que es ajena, cuando en realidad se ha apoderado de un objeto que le pertenece. Y ejemplo de lo segundo, el sujeto cree que el adulterio es delito, o cree que no está permitido matar al agresor para impedir una violación cuando ésta es la única defensa posible ${ }^{85}$.

Pese a la falta de una regulación expresa del error inverso en los preceptos dedicados a la regulación del error en el CP nicaragüense (arts. 25 y 26, al igual que sucede en los CP de Derecho comparado), existe acuerdo en la doctrina al considerar que el error inverso de tipo constituye un supuesto de tentativa inidónea, que será punible o no dependiendo de la forma como se haya regulado la tentativa en el correspondiente $\mathrm{CP}$; en el caso del CP nicaragüense, se ha declarado expresamente la impunidad de la tentativa absolutamente imposible (art. $30 \mathrm{CP}$ nicaragüense), lo que deja abierta la posibilidad para castigar la tentativa relativamente imposible o inidónea (que, junto con la tentativa idónea, estaría definida en el art. $28 \mathrm{CP}$ nicaragüense). En cuanto al error inverso de prohibición, nos encontramos ante lo que se ha denominado un delito putativo, en todo caso impune ${ }^{86}$.

de tipo en los errores sobre las condiciones objetivas de punibilidad, las causas personales de exclusión de la punibilidad y las condiciones de procedibilidad, porque son circunstancias que no han de ser abarcadas por el dolo del sujeto. Y tampoco serán aplicables las reglas del error de prohibición en la valoración de los errores sobre estas circunstancias; y en la doctrina española, BERDUGO GÓMEZ DE LA TORRE/ARROYO ZAPATERO/ FERRÉ OLIVÉ/GARCÍA RIVAS/SERRANO PIEDECASAS/TERRADILLOS BASOCO, PG, 2004, 357; MIR PUIG, PG, $8^{\mathrm{a}}, 2008,269$, para quienes el error sobre las condiciones objetivas de punibilidad y sobre las causas personales de exclusión de la pena es un error irrelevante, ya que son circunstancias que no precisan ser abarcadas por el dolo del sujeto.

85 Ejemplos planteados por LUZÓN PEÑA, PG, I, 1996, 469, 485.

86 Para más detalles sobre el error inverso de tipo y de prohibición, por todos, LUZÓN PEÑA, en: EJB, II, 1995, 


\section{Revista de Derecho}

Evidentemente, esta facilidad en el planteamiento de los errores inversos de tipo y de prohibición desaparece si nos adentramos en los casos problemáticos de errores de tipo y de prohibición: esto es, en el error inverso sobre los elementos normativos del tipo, o el error inverso sobre los elementos de la valoración global del hecho, o el error inverso sobre las leyes penales en blanco.

También resulta problemático decidir cuál deba ser el tratamiento de algunos supuestos de errores inversos de tipo. Así, podemos encontrarnos con supuestos de errores inversos sobre las circunstancias agravantes y sobre los tipos cualificados (el sujeto cree que está atacando a una persona indefensa, cuando no es así, o cree que está ensañándose con su víctima, cuando ésta ha perdido la conciencia o ha muerto con el primer golpe propinado por el autor; o en el delito de hurto, cree que se está apoderando de un objeto de valor cultural, cuando el objeto sustraído carece de tal reconocimiento, o que está matando al padre, cuando en realidad es un extraño), o de error inverso sobre las circunstancias atenuantes y sobre los tipos privilegiados (el sujeto cree que la víctima es un determinado pariente, cuando esta circunstancia actúa como atenuante, o cree que ha reparado los efectos del delito cometido; o en el delito de suicidio, cree que está cooperando en un suicidio, o que ocasiona la muerte de una persona que lo había solicitado y que padece una enfermedad incurable o un padecimiento insoportable, cuando no concurren ninguna de estas circunstancias). No podemos detenernos en cuáles serían las posibles soluciones en el tratamiento de estas modalidades de error, simplemente cabe señalar que previamente será necesario averiguar cuál es el fundamento de la agravación o atenuación de las agravantes/ tipos cualificados y de las atenuantes/tipos privilegiados sobre los que se plantea el error para, a continuación, aplicar los principios de responsabilidad subjetiva y culpabilidad en su tratamiento, sin olvidar que en estos casos parece que sí concurre, en sus presupuestos objetivos y subjetivos, el tipo básico en su modalidad dolosa (al menos cuando se trata del error inverso sobre el tipo cualificado $)^{87}$.

2845; PG, I, 1996, 468; en: EPB, 2002, 663; COBO DEL ROSAL/VIVES ANTÓN, PG, 5a, 1999, 683 s.; MORENO-TORRES HERRERA, en: ZUGALDÍA ESPINAR (dir.)/PÉREZ ALONSO (coord.), PG, 2a, 2004, 694 s.; BUSTOS RAMÍREZ/HORMAZÁBAL MALARÉE, PG, 2a , 2006, 390; ARIAS EIBE, Error en DP, 2007, 135 s.; DÍEZ RIPOLLÉS, PG, 2007, 511; MARTÍNEZ-BUJÁN PÉREZ, DP económico. PG, 2a , 2007, 421 s.; MUÑOZ CONDE/GARCÍA ARÁN, PG, 7ª, 2007, 419 ss.; QUINTERO OLIVARES, PG, 2a , 2007, 442; MIR PUIG, PG, $8^{\mathrm{a}}$, 2008, 271, 356 ss.

87 Sobre el tratamiento del error inverso sobre las agravantes/tipos cualificados, y sobre las atenuantes/tipos privilegiados, vid., BACIGALUPO ZAPATER, PG, 5a , 1998, 239; ZUGALDÍA ESPINAR, en: COBO DEL ROSAL (dir.), Comentarios CP, I, 1999, 686; MAQUEDA ABREU, en: LH Cerezo, 2002, 863 ss.; CASTRO MORENO, El error sobre las circunstancias atenuantes, 2003, 60 ss.; BERDUGO GÓMEZ DE LA TORRE/ 
Pero, sin duda, el caso más discutible en su planteamiento como (posible) error inverso de tipo o como error inverso de prohibición es el relativo al desconocimiento por parte del sujeto de que concurren los presupuestos objetivos de una causa de justificación ${ }^{88}$. Ejemplos, el sujeto que, sin saberlo, evita la agresión ilegítima de la que está siendo víctima un tercero, o el sujeto que al romper los cristales de la vivienda de un tercero, sin saberlo, evita que éste muera asfixiado por un escape de gas, o el agente de la autoridad que, sin saberlo, detiene a un delincuente peligroso en busca y captura.

$\mathrm{Al}$ igual que la mayoría de los $\mathrm{CP}$ de Derecho Comparado (con excepción del CP italiano), el CP nicaragüense ha omitido cualquier referencia a este supuesto de error inverso, lo que resulta una decisión acertada, ya que cualquier tratamiento de esta clase de error implica una determinada concepción en torno a la tipicidad y la antijuridicidad y su exclusión, las causas de justificación, así como sobre la existencia o no de elementos subjetivos en las causas de justificación y, en caso de existir, su caracterización como requisitos esenciales o inesenciales, distinción ésta última que cobra especial relevancia en este texto legal, por la posible aplicación de la regulación de la eximente incompleta en la solución de este error (art. 35.1 CP nicaragüense) ${ }^{89}$.

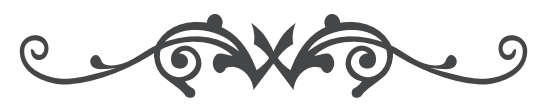

ARROYO ZAPATERO/FERRÉ OLIVÉ/GARCÍA RIVAS/SERRANO PIEDECASAS/TERRADILLOS BASOCO, PG, 2004, 261; FLORES MENDOZA, Error sobre las circunstancias modificativas, 2004, 107 ss.; ARIAS EIBE, Error en DP, 2007, 149 s., 155 ss.; DÍEZ RIPOLLÉS, PG, 2007, 176; MIR PUIG, PG, 8ª 2008, 272 ,

88 Respecto de los otros posibles errores inversos sobre las causas de justificación, el error inverso sobre los límites de la causa de justificación y el error inverso sobre su existencia, se trata de dos modalidades del error inverso de prohibición, por lo que no plantean ninguna peculiaridad. El problema en este caso es previo, esto es, cuando el error afecta a los elementos normativos de las causas de justificación o a los elementos de la valoración global de estas eximentes se trata de decidir si el error inverso sobre tales elementos da lugar al desconocimiento de que concurre la situación objetiva justificante o a un error inverso sobre la existencia o los límites de dicha causa de justificación.

89 Vid., para más detalles sobre las distintas concepciones en torno a los elementos subjetivos en las causas de justificación y el tratamiento del desconocimiento de la concurrencia de los presupuestos objetivos de una causa de justificación, TRAPERO BARREALES, Los elementos subjetivos en las causas de justificación y de atipicidad penal, Comares, Granada, 2000, passim. 